\author{
UNIVERSIDADE DE SÃO PAULO - USP \\ FFCLRP - DEPARTAMENTO DE BIOLOGIA \\ PROGRAMA DE PÓS-GRADUAÇÃO EM BIOLOGIA COMPARADA
}

\begin{abstract}
Status taxonômico de Callichirus major (Say, 1818) sensu lato (Crustacea, Decapoda, Axiidea, Callianassidae) da costa brasileira: taxonomia, sistemática molecular, biologia populacional e reprodutiva
\end{abstract}

Douglas Fernando Peiró

Tese apresentada à Faculdade de Filosofia, Ciências e Letras de Ribeirão Preto da USP, como parte das exigências para a obtenção do título de Doutor em Ciências, Área: BIOLOGIA COMPARADA.

RIBEIRÃO PRETO / SP 


\author{
UNIVERSIDADE DE SÃO PAULO - USP \\ FFCLRP - DEPARTAMENTO DE BIOLOGIA \\ PROGRAMA DE PÓS-GRADUAÇÃO EM BIOLOGIA COMPARADA
}

\title{
Status taxonômico de Callichirus major (Say, 1818) sensu lato (Crustacea, Decapoda, Axiidea, Callianassidae) da costa brasileira: taxonomia, sistemática molecular, biologia populacional e reprodutiva
}

\section{Douglas Fernando Peiró}

Orientador: Prof. Dr. Fernando L.M. Mantelatto

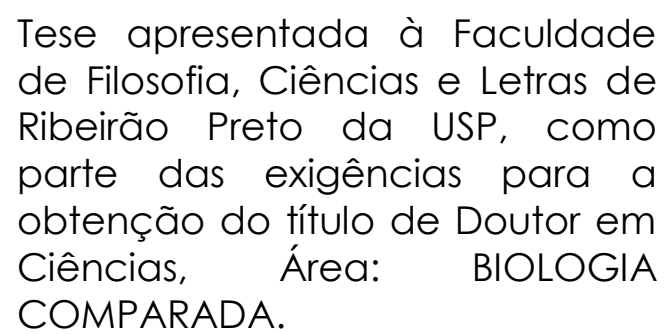

RIBEIRÃO PRETO / SP 
Peiró, Douglas Fernando

Status taxonômico de Callichirus major (Say, 1818) sensu lato (Crustacea, Decapoda, Axiidea, Callianassidae) da costa brasileira: taxonomia, sistemática molecular, biologia populacional e reprodutiva.

Ribeirão Preto, 2012

$158 \mathrm{p}$.

Tese de doutorado. Programa de Pós-Graduação em Biologia Comparada. Departamento de Biologia da Faculdade de Filosofia, Ciências e Letras de Ribeirão Preto da Universidade de São Paulo.

Orientador: Mantelatto, Fernando L.M.

1. Biologia marinha, 2. Callichirus macrotelsonis, 3. 16Smt gene, 4 . Investimento reprodutivo, 5. Fecundidade, 6. Ecologia populacional 


\section{Dedicatória}

Para minha filha Maristela G. Peiró, meu pai Douglas Peiró, minha mãe Maria de Lourdes P. Peiró, minha avó Iracema Schiavinatto Peiró, e para meu irmão Denis A. Peiró. 


\section{Agradecimentos}

Agradeço ao meu orientador Prof. Dr. Fernando L.M. Mantelatto pela orientação criteriosa, por todo conhecimento científico transmitido, pelo incentivo e confiança em todos os assuntos relacionados à minha vida acadêmica. Em fim, agradeço por todas as oportunidades a mim oferecidas durante os sete anos de trabalhos em conjunto. Muito obrigado!

Ao Prof. Dr. Ingo S. Wehrtmann por me receber em estágio acadêmico em seu laboratório e no Museo de Zoología na Universidad de Costa Rica em San José, Costa Rica. Pelo empréstimo e a oportunidade de coletarmos exemplares de Callichirus na costa do Oceano Pacífico e no Mar do Caribe na Costa Rica. Além de seus ensinamentos transmitidos por meio de sugestões no capítulo sobre reprodução - colaboração realizada por decorrência do estágio acadêmico em seu laboratório.

Ao Prof. Dr. Darryl L. Felder por me receber em seu laboratório por decorrência do estágio em meu doutorado sanduíche no Laboratory for Crustacean Research na University of Louisiana at Lafayette, EUA. Pelo empréstimo e doação de exemplares de Callichirus, pela futura colaboração através das críticas e sugestões no capítulo sobre taxonomia.

Ao Prof. Dr. Emerson Contreira Mossolin pelo auxilio nas coletas e discussões a respeito da biologia populacional e reprodutiva de crustáceos Decapoda.

Ao Prof. Dr. Paulo Ricardo Pezzuto pela leitura e sugestões feitas nos relatórios científicos anuais.

Ao Dr. Rafael Robles pelo auxilio no estudo sobre biologia molecular, coletas de exemplares de Callichirus, como também pelas sugestões feitas no capítulo sobre taxonomia.

Agradecimentos a toda equipe do Laboratório de Bioecologia e Sistemática de Crustáceos (LBSC) da FFCLRP da Universidade de São Paulo (Ribeirão Preto). Às pessoas que participaram das diversas coletas e daqueles que colaboraram de alguma forma com este trabalho: Adriane Braga, Álvaro da S. Costa, Ana Francisca, Cris Tudge, Camila de Paula, David Veliz, Emiliano H. Ocampo, Emma Palacios Theil; Emerson C. Mossolin, Fernando L. Mantelatto, Hugo H. Saulino, Ivana Miranda da Silva, Isabela Leone, Leonardo A. Pileggi, Luiz Miguel Pardo, Maíra Clasen Massarani, Mariana Negri Pereira, Natalia M. 
Grilli, Natália Rossi, Raquel C. Buranell, Sandra de Souza Pereira e Tatiana Magalhães.

Agradecimentos aos pesquisadores que coletaram, enviaram ou emprestaram material biológico utilizado neste estudo: Alexandre Oliveira de Almeida, Aline S. Benetti, Daniela Castiglioni, Edvanda A. Souza-Carvalho, Eliana Alves, Fabrício L. Carvalho, Fernando Abrunhosa, F. Augusto, Henry S. Montoya, J.M. Góes, Luís Ernesto A. Bezerra, Marcos Tavares, Mauro Cardoso Jr., Paulo R. Pezzuto, Rony Vieira, Sergio Cleto Fo.

Ao Programa de Pós-Graduação em Biologia Comparada, seus Coordenadores durante o período de meu mestrado e doutorado, membros do conselho, funcionários e alunos. Aos professores e funcionários do Departamento de Biologia da FFCLRP-USP.

Ao Concelho Nacional de Desenvolvimento Científico e Tecnológico (CNPq) pelas bolsas de doutorado (GD Proc. 141446/2009-9) e doutorado sanduíche no exterior (SWE Proc. 201831/2010-4), concedidas durante o período do doutorado.

Este estudo também contou com o apoio de outros projetos coordenados pelo Prof. Dr. Fernando L. Mantelatto. Com apoio do CNPq: Procs. 472746/20049, 471794/2006-6, 473050/2007-2, 471011/2011-8 (Edital Universal e Auxílio Individual a Pesquisa); Procs. 301359/2007-5, 302748/2010-5 (Produtividade em Pesquisa); e Procs. 491490/2004-6, 490122/2006-0, 490353/2007-0 (Projetos de Cooperação Internacional). Com o apoio da Fundação de Amparo a Pesquisa do Estado de São Paulo (FAPESP): Procs. 1998/07454-5, 2002/08178-9 (Projetos Individuais de Pesquisa), 2010/50188-8 (Projeto Temático Biota), 2009/54931-0 (Projeto Coleções Científicas). E com o apoio da Coordenação de Aperfeiçoamento de Nível Superior (CAPES): Proc. 315/2009 (Projeto de Cooperação Internacional).

Ao Convênio CAPES/PROAP pelo suporte financeiro para as coletas e congressos.

Ao Centro de Biologia Marinha da Universidade de São Paulo (CEBIMAR), São Sebastião/SP, sua direção e funcionários, pelo suporte logístico durante os períodos de coletas. 
Ao IBAMA pela concessão da autorização de coleta $n^{\circ}$ 11777-1 MMA/IBAMA/SISBIO de 16/09/07; $n^{\circ}$ 126/05 DIFAP/IBAMA, em nome de Fernando L. M. Mantelatto.

À profa. Dra. Teresa Kasuko Muraoka, ao prof. Dr. Guilherme Rossi Gorni, à profa. Dra. Vanessa Colombo Corbi, ao prof. Dr. Juliano José Corbi, à profa. Dra. Flávia C. Sossae. Assim como ao Centro Universitário de Araraquara (Uniara), a seu Reitor Prof. Dr. Luiz Felipe Cabral Mauro e a todos os professores amigos.

Agradeço ao meu tio Jaime Peiró, por me ter me ensinado o método de mensuração de variação do nível da praia.

Agradeço a toda minha família pelo suporte em minha vida pessoal, em especial para minha filha Maristela G. Peiró, ao meu pai Douglas Peiró, minha mãe Maria de Lourdes Peiró, minha avó Iracema Peiró, ao meu irmão Denis A. Peiró. A todos meus amigos. E acima de tudo, a Deus. 


\section{Sumário}

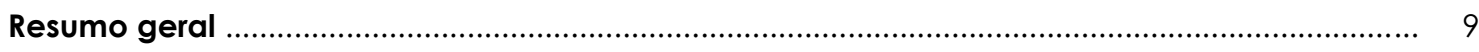

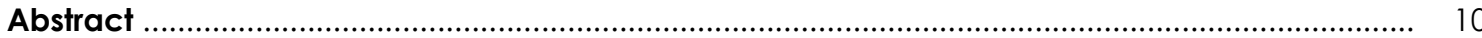

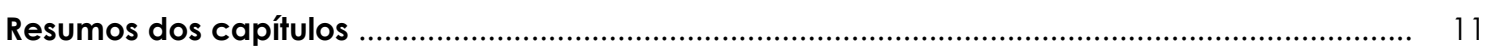

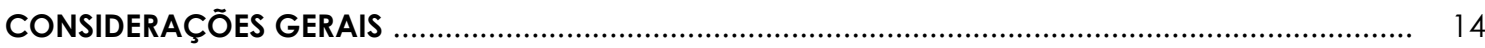

A infraordem Axiidea .................................................................................................... 14

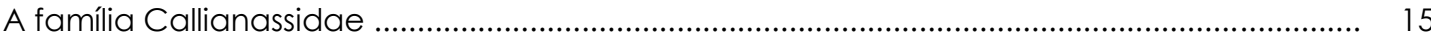

O gênero Callichirus ..................................................................................................... 16

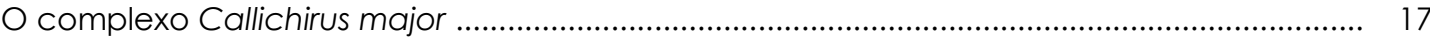

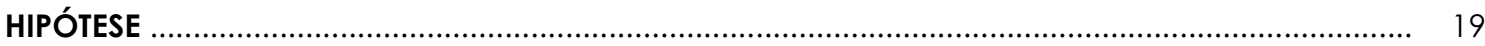

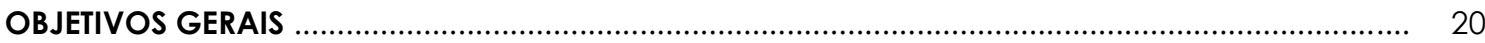

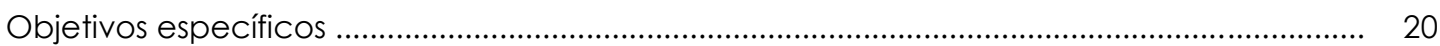

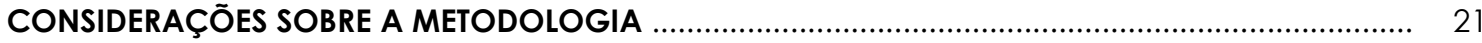

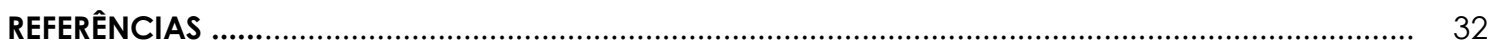

Capítulo I. Designation of Callichirus macrotelsonis (Ortmann, 1893) comb. nov. as the "Brazilian species" of Callichirus major complex (Decapoda: Axiidea: Callianassidae) on the basis of morphological and molecular data

Capítulo II. Reproductive strategy of the ghost shrimp Callichirus macrotelsonis (Ortmann, 1893) (Crustacea: Axidea: Callianassidae) in the southeastern Atlantic: sexual maturity of females, fecundity, egg features and reproductive output.

Capítulo III. Dinâmica populacional de Callichirus macrotelsonis (Ortmann, 1893) (Decapoda, Axiidea, Callianassidae) na praia do Perequê-açu, Ubatuba, litoral norte do Estado de São Paulo 
Esta tese trata, primariamente, da definição do status taxonômico do amplamente conhecido "corrupto de praia" ou "ghost shrimp" Callichirus major (Say, 1818) sensu lato (Decapoda, Axiidea, Callianassidae) ocorrente na costa brasileira (Capítulo I). A definição deste táxon era um tanto incerta até o momento, levando-se em conta a grande similaridade morfológica entre as espécies que compõem o complexo C. major. Alguns estudos morfológicos, moleculares e larvais foram realizados anteriormente de forma isolada, e sem uma abrangência ao longo de toda sua área de distribuição. Entretanto, nenhum destes estudos foi conclusivo quanto à validade ou não do nome $C$. major ser aplicado à espécie brasileira. De forma complementar, esta tese objetivou o estudo sobre o investimento reprodutivo e sobre a ecologia populacional de uma de suas populações do litoral norte do Estado de São Paulo (Capítulos II e III, respectivamente). Os resultados desta tese são apresentados em capítulos separados, devido ao fato deles tratarem de assuntos distintos envolvendo a taxonomia/sistemática molecular, biologia reprodutiva e a ecologia populacional da espécie. Cada capítulo contém suas próprias sessões: Resumo, Introdução, Material \& Métodos, Resultados, Discussão e Referências. Também, cada capítulo apresentado nesta tese é equivalente a um artigo submetido ou a ser submetido a revistas científicas e encontram-se formatados de acordo com as normas das revistas escolhidas. 


\section{Abstract}

This thesis is primarily about the taxonomic status of the ghost shrimp Callichirus major (Say, 1818) sensu lato (Decapoda, Axiidea, Callianassidae) from Brazilian coastlines (Chapter I). The taxonomic status of C. major complex was uncertain until now, due to the very large range of distribution and morphological characters shared among species. Some morphologic, molecular and larval studies were made in isolated perspective and without a distribution range overview before that. None of them were conclusive about the validity to name C. major been applied for the Brazilian species. In a complementary way, this thesis aimed the reproductive output and the population ecology of the species in a sandy beach in the North Shore, State of São Paulo, Brazil (Chapters II and III, respectively). The results of this thesis were presented in distinct chapters due to different approaches related to taxonomy/systematics, reproductive biology and population ecology of this species. Each chapter has its own sections: Abstract, Introduction, Material and Methods, Results, Discussion and References. Those chapters are equivalent to an article submitted or to be submitted to scientific journals, and are formatted according to the author guidelines of each journal. 


\section{Resumos dos capítulos}

\section{Capítulo I. Designação de Callichirus macrotelsonis (Ortmann, 1893) comb.} nov. para a espécie do complexo Callichirus major ocorrente no Brasil (Decapoda: Axiidea: Callianassidae) baseada em dados morfológicos e moleculares

Callichirus major (Say, 1818) sensu lato vem sendo amplamente utilizado para nomear um grupo de espécies ecologicamente e economicamente importantes na costa americana. O status taxonômico deste complexo de espécies é um tanto duvidoso, em parte devido a grande área de distribuição geográfica e devido ao compartilhamento de características morfológicas entre as espécies/populações. Os objetivos deste estudo foram examinar evidencias morfológicas e moleculares para, potencialmente, separar a táxon ocorrente no Brasil das remanescentes espécies do complexo C. major. Foram analisadas diferentes populações ocorrentes na costa brasileira, comparandoas morfologicamente e molecularmente (gene 16S mtDNA) com indivíduos do complexo provenientes de outras regiões. Por meio dos resultados, conclui-se que complexo C. major pode ser separado em, pelo menos, quatro espécies. Neste estudo foi proposto que a espécie ocorrente na América do Norte (localidade tipo) retém o nome Callichirus major (Say, 1818); duas espécies estão em fase de descrição; enquanto que a espécie ocorrente no Brasil passa a ser reconhecida por um nome previamente designado para uma larva marinha de afinidades incertas. Como chamada a atenção pelo Dr. Sergio de A. Rodrigues, a espécie originalmente descrita como Anomalocaris macrotelsonis Ortmann, 1893 corresponde ao quarto estágio larval da espécie de Callichirus da costa brasileira; o que nos leva a adotar a nova combinação Callichirus macrotelsonis (Ortmann, 1893) para nomeá-la. 


\section{Capítulo II. Estratégias reprodutivas de Callichirus macrotelsonis (Ortmann,}

1893) (Decapoda: Callianassidae) de uma praia da costa sudeste do Brasil:

maturidade sexual das fêmeas, fecundidade, características dos ovos e

\section{investimento reprodutivo}

Reprodução e investimento reprodutivo em crustáceos Axiidea é um fenômeno intrigante, uma vez que estes animais possuem um modo de vida críptico é uma grande importância ecológica no revolvimento do sedimento, da matéria orgânica e dos nutrientes. Neste estudo é apresentada a biologia reprodutiva do callianassídeo Callichirus macrotelsonis de uma praia arenosa da costa sudeste do Brasil, por meio do tamanho de maturidade sexual das fêmeas, da fecundidade, das características dos ovos, e do investimento reprodutivo. As fêmeas, neste local, atingem a maturidade sexual em aproximadamente $11,85 \mathrm{~mm}$ de comprimento da área oval da carapaça. A fecundidade aumenta de acordo de acordo com o tamanho das fêmeas, e variou entre 1455 e 9931 ovos (média de 4564 ovos). O volume dos ovos quase duplicou ao longo da embriogênese. A massa de ovos correspondeu, em média, a 13,2\% do peso seco das fêmeas. $O$ alto investimento na reprodução pelos Axiidea é, provavelmente, compensatório ao baixo número de fêmeas ovígeras nas populações. Os (poucos) dados publicados sobre o investimento reprodutivo em Axiidea constituem indicativos de que o investimento na reprodução é superior em relação ao relatado para outros Decapoda. O alto investimento reprodutivo nesta espécie é, provavelmente, um esforço para maximizar a viabilidade da progênie. Estudos com outras espécies podem ajudar a esclarecer se realmente é uma regra entre os Axiidea possuírem um valor de investimento reprodutivo superior ao limite reportado para outros Decapoda. 


\section{Capítulo III. Dinâmica populacional de Callichirus macrotelsonis (Ortmann,}

1893) (Decapoda, Axiidea, Callianassidae) na praia do Perequê-açu, Ubatuba, litoral norte do Estado de São Paulo

Callichirus macrotelsonis habita praias arenosas dissipativas, vivendo individualmente em galerias profundas na zona intermareal. É um importante recurso utilizado como isca, sendo que sua extração descontrolada pode causar alterações em sua estrutura populacional. Os objetivos deste estudo foram avaliar a dinâmica populacional desta espécie na praia do Perequêaçu, Ubatuba/SP, assim como a comparação dos padrões populacionais com outros estudos. Entre set/2008 e jul/2009 foram coletados bimestralmente, com bombas de sucção, 164 exemplares: 67 machos (40,9\%), 94 fêmeas $(57,3 \%)$, sendo 24 ovígeras (14,6\%), e 3 indivíduos danificados (1,8\%); detectou-se uma considerável variação na abundância entre os bimestres coletados. A razão sexual foi de 1:1 entre os bimestres ( $p>0,05)$, com exceção de maio/2009. A densidade média populacional foi de 0,202 \pm 0,494 aberturas $\bullet \mathrm{m}^{-2}$. O período reprodutivo foi contínuo, com um pico sazonal em novembro. O pico de recrutamento foi inferido por meio de evidências indiretas, e ocorre entre dezembro e janeiro. A eficiência de captura foi de $26,6 \%$. Identificou-se forte influência da captura para pesca na dinâmica desta população, principalmente nos meses de verão. Além disso, foi identificado que os padrões populacionais da espécie variam consideravelmente dentro de sua ampla área de ocorrência (do Pará até Santa Catarina), o que constitui forte argumento para se incentivar estudos ecológicos em áreas onde não existem muitos destes registros, principalmente nas costas norte e nordeste do Brasil. 


\section{CONSIDERAÇÕES GERAIS}

\section{A infraordem Axiidea}

A infraordem Axiidea de Saint Laurent, 1979 - estabelecida por De Grave et al. (2009) - é composta por algumas espécies de Decapoda anteriormente reconhecidas para o extinto e parafilético táxon Thalassinidea. Axiidea segue a classificação originalmente proposta como "sessões" por de Saint Laurent (1979a, 1979b), assim como a infraordem Gebiidea de Saint Laurent, 1979 (atualmente estabelecidas como duas infraordens distintas). Essa nova classificação de De Grave et al. (2009) baseou-se na revisão em dados moleculares e morfológicos (Gurney, 1938, 1942; de Saint Laurent, 1979a; 1979b; Sakai, 2005a; Sakai \& Sawada, 2005; Robles et al., 2009), e em estudos genéticos prévios (Tsang et al., 2008a; Tsang et al., 2008b) para dar suporte a esse arranjo.

Os Axiidea (juntos com Gebiidea) são um dos notáveis grupos de animais com hábitos de vida principalmente escavadores do ambiente marinho, habitando sedimentos nas zonas intermareal e submareal rasa (Dworschak, 2005). Podem ser encontrados em fundos de estuários, baías, lagoas costeiras, ou ao longo de praias arenosas, tanto em oceanos tropicais quanto temperados, onde constroem os maiores e mais profundos sistemas de galerias conhecidos no ambiente marinho (Abu-Hilal et al., 1988). Entretanto, apesar de terem hábitos de vida em comum, os membros destes dois grupos, bastante heterogêneos, (como mencionado anteriormente) já vinham sendo relatados como provavelmente não monofiléticos (Dworschak,1992). 


\section{A família Callianassidae}

A família Callianassidae foi estabelecida por Dana, 1852. Posteriormente revisada por Manning \& Felder (1991) (espécies americanas), Sakai, (1999), Sakai (2002) (espécies do Mar de Andaman, Tailândia) e Sakai (2005a, 2005b). Atualmente é composta por 41 espécies divididas entre 10 subfamílias. Além de um grupo de espécies fósseis não alocadas dentro destas 10 subfamílias (De Grave et al., 2009).

Os membros desta família desempenham um importante papel em habitats bentônicos de sedimentos não consolidados (Botter-Carvalho et al., 2007), promovendo a bioturbação, que influencia diretamente nas propriedades químicas (Waslenchuk et al., 1983; Ziebis et al., 1996, Bird et al., 2000) e físicas do sedimento (Suchanek, 1983; Suchanek \& Colin, 1986; Wynberg \& Branch, 1994). Sua atividade aumenta significativamente o revolvimento e retorno do sedimento e da matéria orgânica, além da ciclagem de nutrientes (Waslenchuk, et al., 1983; Branch \& Pringle, 1987; Ziebis et al., 1996; Webb \& Eyre, 2004) e a redistribuição de metais e contaminantes (Suchanek et al., 1986; Abu-Hilal et al., 1988).

Seus complexos sistemas de galerias criam, modificam, e mantém um mosaico de habitats para outros organismos (Berkenbusch \& Rowden, 2003), causando alterações na estrutura das comunidades de bactérias e animais bentônicos (Berkenbusch et al., 2000; Dworschak, 2000). Estas estruturas promovem micro-habitats favoráveis para a fauna associada (Berkenbusch \& Rowden, 2003), composta por caranguejos pinnoterídeos, bivalves, copépodes e tanaidáceos (Rodrigues \& Shimizu, 1997; Peiró \& Mantelatto 2011; Peiró et al., 2011; Peiró et al., 2012). 


\section{O gênero Callichirus}

O gênero Callichirus foi estabelecido por Stimpson (1866), sendo Callichirus major (Say, 1818) da região sudeste (Flórida, Carolinas do Norte e Sul) dos Estados Unidos a espécie tipo. No entanto, este gênero só veio a ser reconhecido definitivamente a partir da revisão feita por Manning \& Felder (1986). Anteriormente a esse trabalho, o táxon foi considerado com sendo: 1) um subgênero de Callianassa (Leach, 1814) (e.g., Borradaile,1903; de Man, 1928a, b; Schmitt, 1935; Rodrigues, 1971); 2) um gênero distinto compreendendo várias espécies atribuídas anteriormente à Callianassa (e.g., de Saint Laurent, 1973, Le Loeuff \& Intès, 1974, de Saint Laurent \& Le Loeuff, 1979); e também 3) uma sinonímia de Callianassa (e.g., by Biffar, 1971, Poore \& Griffin, 1979). Possivelmente este confuso cenário se perdurou por durante muito tempo, provavelmente devido à publicação de trabalhos sem a visualização de espécimes de C. major, assim como pela publicação de outros sem figuras, fotos e descrições detalhadas de espécimes completos. Somente a partir do trabalho de Rodrigues (1971) começaram a ser apresentadas melhores ilustrações (Manning \& Felder, 1986).

Callichirus tem como características diagnósticas (segundo a redefinição de Manning \& Felder, 1986): pedúnculos oculares alongados, tanto na região pré-corneal como na lança pós-corneal. Quela maior de machos adultos muito alargada, com os três segmentos distais igual ou duas vezes o comprimento da carapaça. Seguimentos abdominais 3-6 com uma distinta ornamentação visível dorsalmente; cada segmento possui tufo de cerdas na região mediolateral. Telson muito mais curto que os urópodos, muito mais comprido do que longo, com ondulações mediais. Endopodos uropodiais com 
forma de alça (vírgula), muito delgados, de 2,5 a 4 vezes mais longo do que largo, com a maioria das setas concentradas em um tufo apical.

\section{O complexo Callichirus major}

Callichirus major sensu lato (SAY, 1818) habita o Atlântico Ocidental, da Carolina do Norte à Florida (EUA), passando pelo Golfo do México, Colômbia, Venezuela e Brasil (do Pará até Santa Catarina) (Melo, 1999; Staton \& Felder, 1995; Abrunhosa et al., 2008), e com um grande hiato do registro de ocorrência em países da América Central. Este táxon é encontrado em praias arenosas dissipativas (Botter-Carvalho et al., 2002; 2007) e apresenta um comportamento críptico, vivendo individualmente nas galerias profundas na zona intermareal, geralmente abaixo do nível médio de marés (Frankenberg et al., 1967; Rodrigues \& Shimizu, 1997).

Este taxon é um importante recurso econômico devido a sua ampla utilização como isca viva por pescadores em muitas áreas costeiras (Wynberg \& Branch, 1994; Rodrigues \& Shimizu, 1997; Contessa \& Bird, 2004; Skilleter et al., 2005); Inclusive ao longo do litoral brasileiro, com maior intensidade a partir dos anos 80 (Borzone \& Souza, 1996; Souza \& Borzone, 2003). Algumas espécies da família Callianassidae são utilizadas como isca devido à sua qualidade como tal e pela facilidade de sua captura (Peiró, 2008). A extração descontrolada para tal finalidade pode causar alterações em sua estrutura populacional como também na de outras espécies existentes no sedimento, incluindo as simbiontes (Wynberg \& Branch, 1991).

O status taxonômico de Callichirus major s. I. (complexo C. major) é um tanto incerto, levando-se em conta as diferentes populações distribuídas ao longo de sua ampla área de ocorrência, e também devido a grande 
similaridade morfológica entre elas. Rodrigues (1985), em um estudo sobre crescimento relativo dos quelípodos, detectou diferenças morfológicas entre exemplares provenientes do Brasil e da Carolina do Norte (EUA). Posteriormente, Staton \& Felder (1995) estudando a variação genética de populações do Golfo do México e da costa Atlântica norte americana e colombiana, concluíram que os exemplares da Colômbia eram suficientemente distintos para não serem considerados pertencentes à mesma espécie (Rodrigues \& Shimizu, 1997). Adicionalmente, diferenças morfológicas e comportamentais em estágios larvais foram também reportadas entre populações do Golfo do México e da costa Atlântica por Strasser \& Felder (1999a, 1999b), quando também comparada com as do Brasil (Rodrigues, 1976).

Recentemente, coletando na costa Pacífica das América do Norte Felder \& Robles (2009) notaram a presença de pelo menos uma espécie afim a Callichirus major s. I., o que foi corroborado por D.F. Peiró e F.L. Mantelatto, que coletando na costa Pacífica da Costa Rica, também produziram mais amostras desta entidade taxonômica ainda não descrita. Tendo em vista este intrigante cenário, é possível que nesta ampla distribuição geográfica (Rodrigues \& Shimizu, 1997) - e, inclusive, a partir de agora abrangendo dois oceanos separados por um istmo - esteja presente um complexo de espécies muito próximas, nunca antes avaliadas sobre a ótica filogenética.

O complexo de espécies é diagnosticado por membros do gênero Callichirus que tem olhos que terminam em forma de lança ou em ângulo obtuso (C. major e spp. relacionadas) (Felder \& Robles, 2009; Capítulo I).

Certamente a distinção e a correta identificação das prováveis espécies do complexo serão benéficas para futuros trabalhos sobre biologia e 
ecologia, por exemplo. Com o uso combinado das diferentes ferramentas propostas neste trabalho e com a colaboração de especialistas do táxon, é possível que haja uma nomeação/re-nomeação das populações de C. major s. I. em distintas espécies.

\section{HIPÓTESE}

Devido a indefinição do atual status taxonômico de C. major s. I., segundo as informações levantadas anteriormente, a hipótese principal deste trabalho foi testar se:

Ho - Existe uma única espécie, com plasticidade refletida em diferentes características morfológicas e ecológicas.

$H_{1}$ - Existe de um complexo de espécies relacionadas, distribuídas ao longo desta ampla área de ocorrência. 


\section{OBJETIVOS GERAIS}

Os objetivos deste trabalho estiveram primariamente focados no esclarecimento do status taxonômico da "espécie brasileira" do complexo C. major, descrito por meio de dados morfológicos e moleculares; assim como o estudo sobre a ecologia e a reprodução de uma população do litoral norte do Estado de São Paulo, sendo estes resultados comparados com as diferentes populações registrados na literatura científica.

\section{Objetivos específicos}

1. Esclarecer o status taxonômico da "espécie brasileira" do complexo C. major com base na análise morfológica de exemplares provenientes de distintas populações ao longo de sua distribuição geográfica para subsidiar a possível validade específica. Ainda, por meio da utilização do gene $16 \mathrm{~S}$ mtDNA, pretendeu-se avaliar a diferenciação genética entre as populações e/ou entre as espécies.

2. Caracterizar aspectos biológicos/ecológicos da população residente na praia do Perequê-açu, Ubatuba/SP, utilizando-se das informações populacionais e reprodutivas como: abundância sazonal, frequência de indivíduos em classes de tamanho, razão sexual, densidade, períodos reprodutivo e de recrutamento, eficiência de captura, fecundidade, tamanho dos ovos e investimento reprodutivo. Além disso, objetivou a descrição de seu estado de conservação na costa brasileira. 


\section{CONSIDERAÇÕES SOBRE A METODOLOGIA}

As metodologias referentes a cada estudo encontram-se detalhadamente descritas nos distintos capítulos, não diferente da apresentada Capítulo I, o qual a metodologia encontra-se em um formato direcionado para artigo e totalmente replicável. No entanto, aqui nesta sessão, optou-se em descrever de forma mais minuciosa a metodologia do estudo do material taxonômico assim como da análise dos dados moleculares, visando um aprofundamento pessoal no assunto e também visando fornecer base para estudos posteriores, para colegas de laboratório ou outros que tenha acesso à tese.

\section{Estudo do material taxonômico}

Exemplares provenientes de diversos pontos da distribuição geográfica de C. major s. I. (Figura 1) foram obtidos por meio de coletas (Licença permanente para coleta de material zoológico $\mathrm{n}^{\circ} 11777-1$ MMA/IBAMA/SISBIO de 16/09/07; no 126/05 DIFAP/IBAMA), empréstimos e doações vindas de diferentes coleções carcinológicas do Brasil e do exterior. Os roteiros das coletas realizadas durante esse projeto tiveram como base o conhecimento das áreas de ocorrência e/ou localidades reportadas para o território brasileiro (Melo, 1999) e no exterior. Em alguns locais, de onde não haviam espécimes depositados em coleções, ou então locais que não possuíam registro na literatura científica, foram efetuadas expedições de coleta. Todas as áreas amostradas foram mapeadas por GPS (Global Position System). As capturas dos espécimes em suas galerias foram feitas com duas bombas manuais de sucção (comprimento $\approx 1 \mathrm{~m}$ ) [metodologia estabelecida por Rodrigues (1966); e similar a descrita por Manning (1975)]. Os espécimes coletados foram 
devidamente etiquetados e armazenados em frascos contendo álcool 80\%, e encontram-se tombados na Coleção Carcinológica do Departamento de Biologia da Faculdade de Filosofia Ciências e Letras de Ribeirão Preto da Universidade de São Paulo (CCDB-FFCLRP-USP), Ribeirão Preto/SP, Brasil.

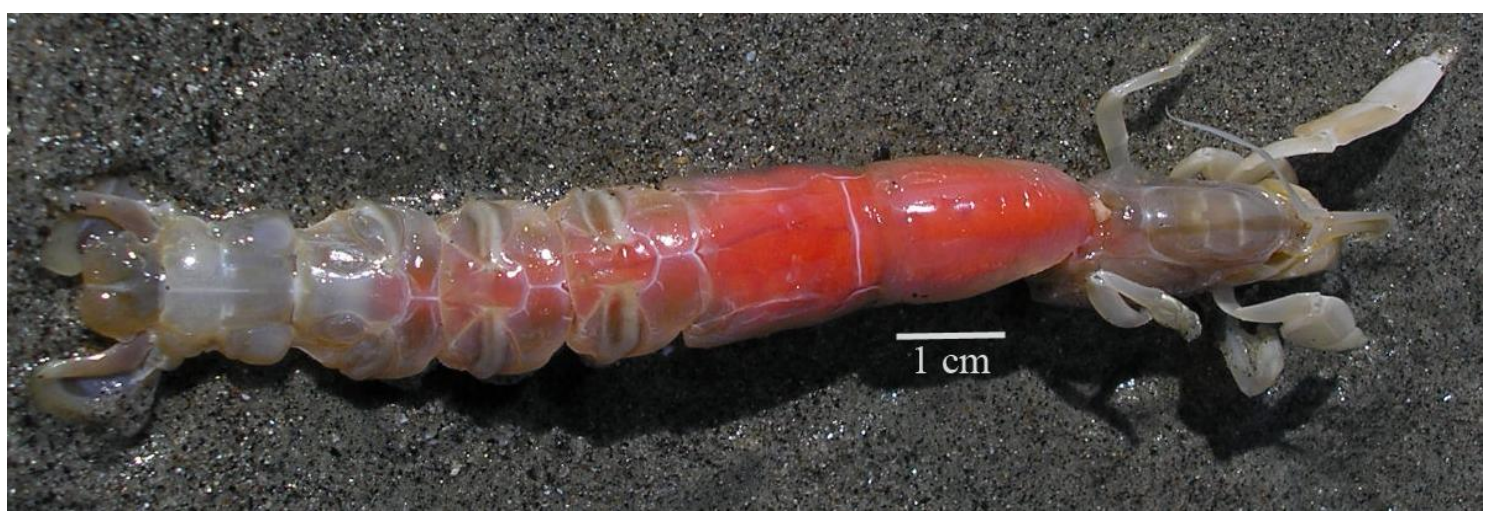

Figura 1. Callichirus major (SAY, 1818) sensu lato fêmea, da Praia do Perequêaçu, Ubatuba/SP.

Além da análise de material depositado na Coleção Carcinológica do Departamento de Biologia da FFCLRP-USP, foram realizadas visitas às coleções carcinológicas do Museu de Zoologia da Universidade de São Paulo (MZUSP), São Paulo/SP, Brasil; ao Museo de Zoología da Universidad de Costa Rica (MZUCR), San José, Costa Rica; e à University of Lovisiana at Lafayette's Zoological Collection (ULLZ), Lafayette/LA, EUA. Além de informações levantadas por meio das visitas a estas coleções, contou-se também com empréstimos de material biológico vindo destas coleções já mencionadas anteriormente, além das coleções: Senckenberg Forschungsinstitut und Naturmuseum (Senckenberg-Mus), Frankfurt am Main, Alemanha; Coleção Carcinológica do Departamento de Oceanografia da Universidade Federal de Pernambuco (CCDO/UFPE), Recife/PE, Brasil; Coleção Carcinológica do 
Museu de Zoologia da Universidade Estadual de Santa Cruz (MUZUESC), Ilhéus/BA, Brasil.

\section{Análise morfológica dos exemplares}

Anteriormente ao estudo morfológico, foi realizado um levantamento e análise das descrições e redescrições das espécies de Callichirus das Américas, assim como de trabalhos que revisaram a morfologia do grupo. Esta análise teve o objetivo de mapear os caracteres diagnósticos do gênero, das espécies e das possíveis variações interespecíficas (e.g. em Say, 1818; Stimpson, 1866; de Man, 1928a, b; Rodrigues, 1971; Manning \& Felder 1986; Manning \& Felder 1991).

A revisão taxonômica foi feita utilizando-se o maior número de exemplares possível, provenientes do maior número de localidades com registro na distribuição geográfica de C. major s. I. Esta análise foi feita com base na comparação dos caracteres morfológicos de indivíduos adultos e juvenis, verificando e acrescentando novos dados às descrições já existentes

de C. major s. s. e s. I. (e.g. em Say, 1818; Stimpson, 1866; de Man, 1928a, b; Rodrigues, 1971; Manning \& Felder 1986; Manning \& Felder 1991).

As principais estruturas morfológicas utilizadas para a revisão, diagnose, descrição e re-descrições foram as de maior variabilidade neste complexo: a carapaça, os pereiópodos (quela), o télson e os urópodos. A lista do material analisado pode ser encontrada no Capítulo I. Todas as observações e desenhos foram realizados sob estereomicroscópio MZ6 LEICA ${ }^{\circledR}$ e SV6 Zeiss ${ }^{\circledR}$ provido de câmara clara. As descrições e re-descrições seguiram a terminologia utilizada por Rodrigues (1971) (Figura 2). 
A diferenciação entre machos e fêmeas foi feita de acordo com a localização dos gonóporos, sendo que nos machos estão localizados nas coxas do quinto par de pereiópodos, e nas fêmeas localizados no terceiro par. Além disso, foram utilizados os caracteres sexuais secundários como: o dimorfismo do quelípodo maior dos machos, que possuem um dente proximal na face ventral do mero (Melo, 1999); e pelos pleópodos dos machos adultos reduzidos, sendo mais desenvolvidos nas fêmeas com finalidade do incubamento dos ovos.

Com a intenção de verificar o tamanho dos espécimes foram realizadas as medidas: comprimento da área oval da carapaça (CO), comprimento máximo do abdômen (CA, no terceiro segmento), aferidas com um paquímetro de precisão 0,05 mm (Zaaz ${ }^{\circledR}$ (Figura 3). 


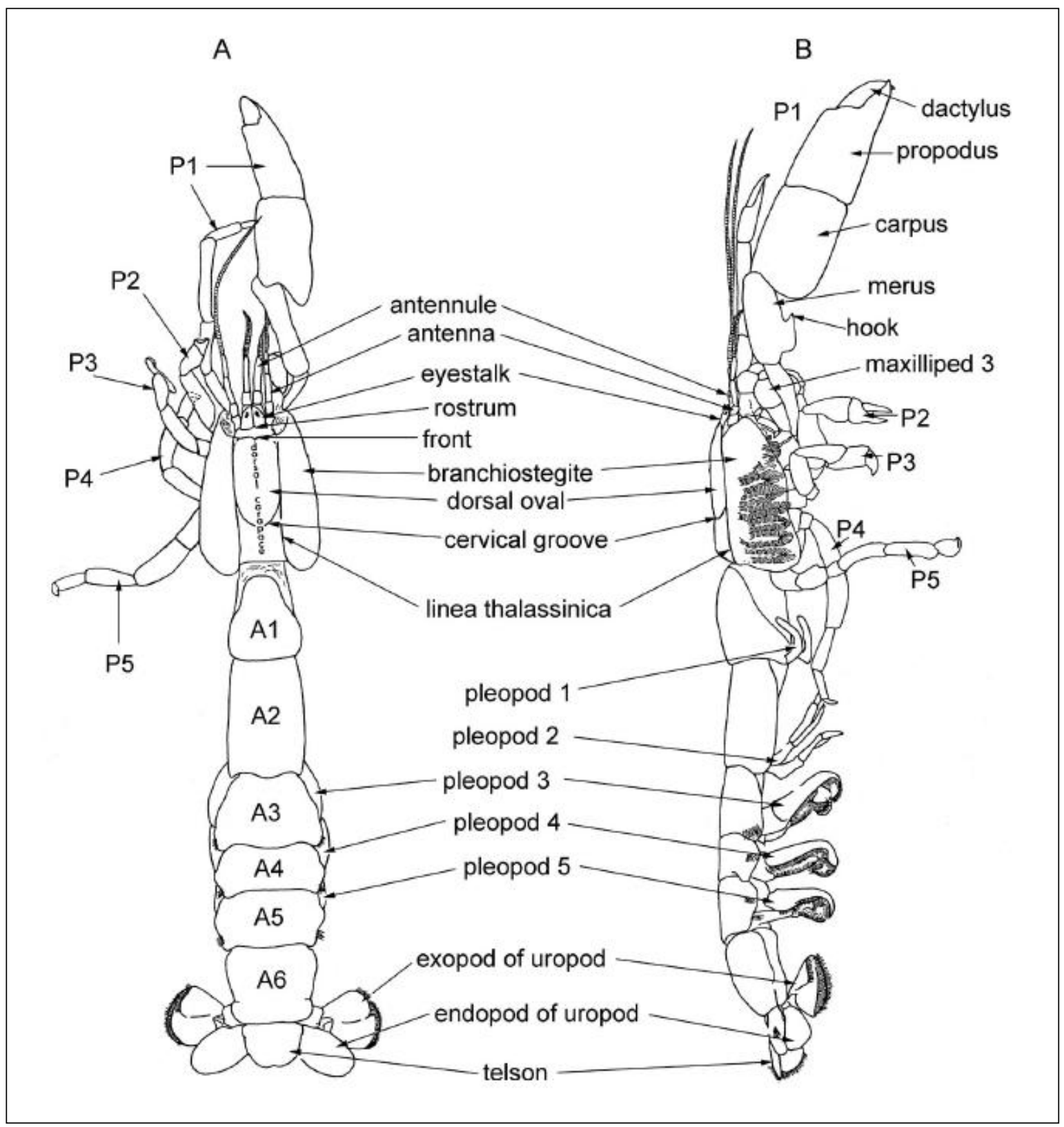

Figura 2. Morfologia geral de Axiidea, (A) vista dorsal; (B) vista lateral. Modificado de Biffar (1971) and Heard et al. (2007). P1-5: pereopods 1-5; A 1-6: abdominal segments $1-6$. 


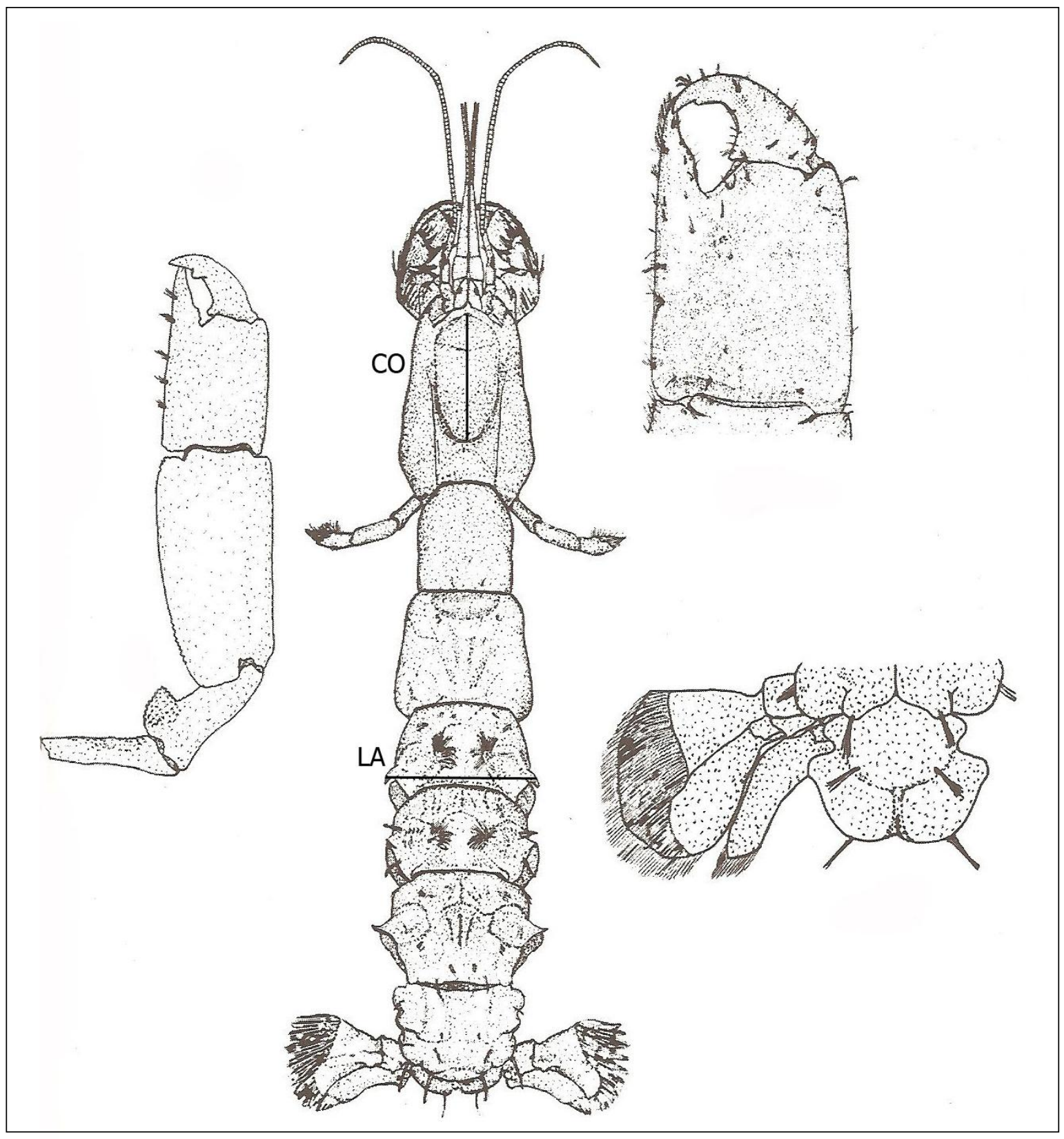

Figura 3. Callichirus major (SAY, 1818) sensu lato $(103,0 \mathrm{~mm}$ de comprimento total). Modificado de Melo (1999). Comprimento da área oval da carapaça (CO), largura máxima do abdômen (LA) (terceiro segmento). 


\section{Obtenção e análise dos dados moleculares}

Os genes provenientes do DNA mitocondrial apresentam regiões bastante conservativas, também com regiões de evolução rápida. Por isso, estes genes são usados tanto para estudos sobre inferência filogenética, assim como para estudos sobre variabilidade inter-populacionais (Matioli, 2001).

O gene 165 mtDNA foi escolhido para ser usado como o marcador molecular neste estudo. Trata-se de um gene estrutural não codificante, que é bastante conservativo. É utilizado na reconstrução filogenética animal em diversos níveis de generalidade (inclusive em Crustacea) para a resolução de questões taxonômicas e evolutivas (Schubart et al., 2000a, b; Torati, 2009). Neste estudo o gene foi usado para verificar a existência de espécies distintas dentro do complexo C. major.

\section{Extração do mtDNA}

O DNA genômico total foi extraído do tecido muscular dos quelípodos ou do abdômen dos espécimes previamente determinados, seguindo a metodologia de Mantelatto et al. (2006, 2007, 2009), Pileggi \& Mantelatto (2010), e Vergamini et al. (2011), com algumas alterações visando a adequação ao material aqui utilizado. A extração de DNA de alguns exemplares que foram previamente fixados em formol também seguiu o protocolo descrito a seguir, porém com algumas modificações adaptadas e modificadas do protocolo de Kohlsdorf \& Wagner (2006) e Pileggi (2009).

O tecido muscular proveniente dos quelipodos ou dos pleópodos, após ter sido retirado do animal, foi incubado até sua total dissolução em $600 \mu \mathrm{L}$ de tampão lise juntamente com $200 \mu \mathrm{L}$ de proteinase $\mathrm{K}(\mathrm{PK})(500 \mu \mathrm{g} / \mathrm{mL})$ a $55^{\circ} \mathrm{C} . \mathrm{O}$ tecido muscular, quando remanescente a este processo, foi macerado. As 
proteínas foram separadas pela adição de $200 \mu \mathrm{L}$ de acetato de amônio 7,5M anteriormente a centrifugação (Centrifuga Eppendorf ${ }^{\circledR}$ 5417R). O DNA foi precipitado pela adição de $700 \mu \mathrm{L}$ de isopropanol resfriado e por subsequente centrifugação, permanecendo descansando por $24 \mathrm{~h}$ a $-20^{\circ} \mathrm{C}$. O pellet resultante do processo foi lavado com $15 \mu \mathrm{L}$ de ETOH 70\%, liofilizado (Concentrator Eppendorf ${ }^{\circledR}$ 5301) e ressuspendido em $20 \mu \mathrm{L}$ de tampão TE.

\section{Concentração de DNA extraído}

A concentração de DNA a ser utilizado no PCR foi estimada por observação em eletroforese em gel de agarose $1 \%$ e fotografada com uma câmera digital (Olympus ${ }^{\circledR}$ C-7070) em um transiluminador UV (UVP ${ }^{\circledR}$ Transluminator M20). Tal procedimento possibilitou adequar a concentração do DNA extraído à concentração necessária para a realização da amplificação dos genes de interesse pela técnica de PCR (Polymerase Chain Reaction) (Sambrook et al., 1989).

\section{Amplificação do DNA pela técnica de PCR (Polymerase Chain Reaction)}

As etapas elencadas deste ponto em diante foram modificadas de Torati (2009) e Pileggi \& Mantelatto (2010), sendo ajustadas para este estudo algumas concentrações de reagentes e o tempo dos ciclos termais nos PCRs.

Os fragmentos de interesse dos genes mitocondriais $16 \mathrm{~S}$ foram amplificados a partir do DNA extraído, por meio da técnica de PCR (Polymerase Chain Reaction) (Sambrook et al., 1989) em um termociclador (Thermo ${ }^{\circledR}$ Thermal Cycler PxE 0.2 ou Applied Biosystems ${ }^{\circledR}$ Veriti 96 Well Thermal Clycler) utilizando-se dos seguintes primers universais (Schubart et al., 2000a, b; Schubart et al., 2002): 


$\begin{array}{lll}\text { Gene } & \text { Primer } & \text { Sequência } \\ 16 \mathrm{~S} & 16 \mathrm{H} 2 & \text { (5'-AGATAGAAACCAACCTGG-3') } \\ 16 \mathrm{~S} & 16 \mathrm{SL2} & \text { (5'-TGCCTGTTTATCAAAAACAT-3') }\end{array}$

A reação de PCR foi realizada para um volume total de $25 \mu \mathrm{L}$ contendo: 6,5 $\mu \mathrm{L}$ de água destilada e deionizada, $5 \mu \mathrm{L}$ de Betaína (5M), $4 \mu \mathrm{L}$ de DNTP's (10 $\mathrm{mM}), 3 \mu \mathrm{L}$ de Taq Buffer, $3 \mu \mathrm{L}$ de $\mathrm{MgCl}_{2}(25 \mathrm{mM}), 1 \mu \mathrm{L}$ de primer $1,1 \mu \mathrm{L}$ de primer 2, 0,5 $\mathrm{\mu L}$ de Thermus aquaticus polimerase (Taq), $1 \mu \mathrm{L}$ de DNA em concentração previamente calculada. Quando a concentração DNA foi diferente de $1 \mu \mathrm{L}$, a quantidade de água destilada e deionizada foi reajustada para que o volume total fosse de $25 \mu \mathrm{L}$.

A amplificação do DNA por PCR foi realizada com os seguintes ciclos termais: desnaturação inicial a $95^{\circ} \mathrm{C}$ por 5', anelamento por 40 ciclos (45" à $95^{\circ} \mathrm{C}, 45^{\prime \prime}$ à $48^{\circ} \mathrm{C}, 1^{\prime}$ à $72^{\circ} \mathrm{C}$ ), extensão final por $3^{\prime}$ à $72^{\circ} \mathrm{C}$. Os resultados das PCRs foram submetidos à eletroforese em gel de agarose 1\%, corado com Gel Red, e visualizados no transiluminador UV. Objetivando verificar a qualidade das bandas e a possibilidade de contaminação, utilizou-se um grupo controle com todos os reagentes do PCR, exceto DNA. O tamanho das bandas de DNA foi verificado com o marcador (gene ruler).

\section{Purificação do DNA amplificado}

Os produtos do PCR foram purificados por meio do kit SureClean ${ }^{\circledR}$, utilizando-se o protocolo da marca. 


\section{PCR para o sequenciamento}

A reação de PCR para sequenciamento foi realizada em um sequenciador automatizado por meio do kit de reação ABI Big Dye ${ }^{\circledR}$ Terminator Cycle Sequencing Mix (Applied Biosystems), para um volume total de $20 \mu \mathrm{l}$. Contendo, $6 \mu \mathrm{l}$ Big Dye Terminator Sequencing Buffer $(2,5 \mathrm{x}), 2 \mu \mathrm{ABI}$ Big Dye ${ }^{\circledR}$ Terminator Cycle Sequencing Mix (deoxinucleotídeos, dideoxinucleotídeos fluorescentes, enzima Taq DNA-Polimerase), primer $(10 \mu \mathrm{M})$ e $2 \mu \mathrm{l}$ ou $1 \mu \mathrm{l}$ (dependendo da concentração previamente checada) do produto do PCR previamente purificado, e água destilada e deionizada para complementar o volume final, modificado de Torati (2009) e Pileggi \& Mantelatto (2010).

A reação de PCR para o sequenciamento teve os seguintes ciclos termais: desnaturação inicial: 2' à $96^{\circ} \mathrm{C}$ (1 ciclo); anelamento (35 ciclos): 45" 'à $96^{\circ} \mathrm{C} ; 30^{\prime \prime}$ '̀ $50^{\circ} \mathrm{C}$; extensão final por $4^{\prime}$ à $60^{\circ} \mathrm{C}$.

\section{Purificação e precipitação do DNA para o sequenciamento}

Após o processo de amplificação do DNA para o sequenciamento, as amostras foram purificadas por meio de um processo de precipitação. Nesse processo, foi adicionado e misturado $80 \mu \mathrm{l}$ de isopropanol $75 \%$ no produto final do PCR para sequenciamento. Seguiu-se uma leve agitação no vortex e incubação a temperatura ambiente por 15' e centrifugado, descartando-se o sobrenadante em seguida. O precipitado foi secado a temperatura ambiente, lavado em seguida com $200 \mu$ de etanol $70 \%$ e centrifugado. O etanol foi completamente removido por meio da centrifugação, com a placa invertida e apoiada em papel absorvente. O precipitado foi incubado a temperatura ambiente por $1 \mathrm{~h}$. As amostras foram então re-suspendidas em $10 \mu \mathrm{l}$ de formamida Hi-Di (Applied Biosystems ${ }^{\circledR}$ ). Os produtos desta PCR foram 
colocados no sequenciador (ABI 3100 Genetic Analyzer ${ }^{\circledR}$ ) do Departamento de Biologia da Faculdade de Filosofia Ciências e Letras de Ribeirão Preto (FFCLRP), da Universidade de São Paulo (USP) ou então do Departamento de Tecnologia da Faculdade de Ciências Agrárias e Veterinárias de Jaboticabal (FCAV) da Universidade Estadual Paulista "Júlio de Mesquita Filho" (UNESP). A leitura das bases foi analisada pelo programa de computador ABI 3100 Data Collection.

\section{Edição das sequências}

O sequenciamento de ambas as fitas foi realizado a fim de obter uma sequência de consenso (consequentemente de maior confiabilidade) utilizando-se o programa BioEdit v7.1.3 (Hall, 2005). Os fragmentos do DNA obtidos a partir da metodologia empregada foram comparados com as outras sequências do banco de dados do NCBI (The National Center for Biotechnology Information) pelo programa de pesquisa BLAST (The Basic Local Alignment Search Tool - http://blast.ncbi.nlm.nih.gov), que visa encontrar regiões de similaridade local entre sequências para a confirmação de identidades das sequências. Todas as sequências obtidas neste estudo foram depositados no GenBank (http://www.ncbi.nlm.nih.gov/genbank/).

\section{Análises dos dados moleculares}

As análises dos dados moleculares foram realizadas utilizando as sequências parciais do gene 165 (obtidas como descrito acima), além de sequências de representantes do mesmo gênero disponíveis no GenBank. Com o intuito de obter um bom enraizamento da árvore para as análises do gene 16S foram utilizadas sequências de espécies congêneres: C. major sensu 
stricto, C. major sensu lato, C. seillacheri (Bott, 1955) e C. islagrande (Schimitt, 1935); além de uma espécie da mesma subfamília (Callichirinae): Sergio mirim (Rodrigues 1971) (a lista de spp. está disponível no Capítulo I). Por ser uma porção conservada do gene 16S, tentou-se obter a sequência deste marcador de pelo menos dois indivíduos de cada população.

Os demais procedimentos específicos para a análise dos dados moleculares encontram-se descritos detalhadamente no Capítulo I.

\section{REFERÊNCIAS}

Abrunhosa, F. A., D. C. B. Arruda, D. J. B. Simith \& C. A. M. Palmeira (2008) The importance of feeding in the larval development of the ghost shrimp Callichirus major (Decapoda: Callianassidae). Anais da Academia Brasileira de Ciências, 80, 445-453.

Abu-Hilal, A., M. Badran \& J. De Vaugelas (1988) Distribution of trace elements in Callichirus laurae burrows and nearby sediments in the Gulf of Aquaba, Jordan (Red Sea). Marine Environmental Research, 25, 233-248.

Berkenbusch, K. \& A. A. Rowden (2003) Ecosystem engineering - moving away from 'just-so' stories. New Zealand Journal of Ecology, 27, 67-73.

Berkenbusch, K., A. A. Rowden \& P. K. Probert (2000) Temporal and spatial variation in macrofauna community composition imposed by ghost shrimp Callianassa filholi bioturbation. Marine Ecology Progress Series, 192, 249-257.

Biffar, T. A. (1971) The genus Callianassa (Crustacea, Decapoda, Thalassinidea) in south Florida, with keys to the Western Atlantic species. Bulletin of Marine Science, 21, 637-715.

Bird, F. L., P. I. Boon \& P. D. Nichols (2000) Physicochemical and microbial properties of burrows of the deposit-feeding thalassinidean ghost shrimp Biffarius arenosus (Decapoda: Callianassidae). Estuarine, Coastal and Shelf Science, 51, 279-291.

Borradaile, L. A. (1903) On the classification of the Thalassinidea. The Annals and Magazine of Natural History, series 7, 12, 534-551.

Borzone, C. A. \& J. R. B. Souza (1996) A extração de corrupto Callichirus major (Decapoda: Callianassidae) para uso como iscas em praias do litoral do Paraná: características da pesca. Nerítica, 10, 67-79. 
Botter-Carvalho, M. L., P. J. P. Santos \& P. V. V. C. Carvalho (2002) Spatial Distribution of Callichirus major (Say 1818) (Decapoda: Callianassidae) on a sandy beach, Piedade, Pernambuco, Brazil. Nauplius, 10, 97-109.

Botter-Carvalho, M. L., P. J. P. Santos \& P. V. V. C. Carvalho (2007) Population dynamics of Callichirus major (Say, 1818) (Crustacea, Thalassinidea) on a beach in northeastern Brazil. Estuarine Coastal and Shelf Science, 71, 508-516.

Branch, G. M. \& A. Pringle (1987) The impact of the sand prawn Callianassa kraussi Stebbing on sediment turnover and on bacteria, meiofauna, and benthic microflora. Journal of Experimental Marine Biology and Ecology, 107, 219-235.

Contessa, L. \& F. L. Bird (2004) The impact of bait-pumping on populations of the ghost shrimp Trypaea australiensis Dana (Decapoda: Callianassidae) and the sediment environment. Journal of Experimental Marine Biology and Ecology, 304, 75-97.

Dana, J. D. 1852. Crustacea. Part I. C. Sherman, Philadelphia.

De Grave, S., N. D. Pentcheff, S. T. Ahyong, T.-Y. Chan, K. A. Crandall, P. C. Dworschak, D. L. Felder, R. M. Feldmann, C. H. J. M. Fransen, L. Y. D. Goulding, R. Lemaitre, M. E. Y. Low, J. W. Martin, P. K. L. Ng, C. E. Schweitzer, S. H. Tan, D. Tshudy \& R. Wetzer (2009) A classification of living and fossil genera of decapoda crustaceans. The Raffles Bulletin of Zoology, Supplement No. 21, 1-109.

Dworschak, P. C. (1992) The Thalassinidea in the Museum of Natural History, Vienna; with some remarks on the biology of the species. Annalen des Naturhistorischen Museums in Wien, 93B, 189-238.

Dworschak, P. C. (2000) On the burrows of Lepidophthalmus lovisianensis (Schmitt, 1935) (Decapoda: Thalassinidea: Callianassidae). Senckenbergiana Maritima, 30, 99-104.

Dworschak, P. C. (2005) Global diversity in the Thalassinidea (Decapoda): an update (1998-2004). Nauplius, 13, 57-63.

Felder, D. L. \& R. Robles. (2009) Molecular phylogeny of the family Callianassidae based on preliminary analyses of two mitochondrial genes. In: Martin, J. W., K. A. Crandall \& D. L. Felder. Decapod Crustacean Phylogenetics. CRC Press, Taylor \& Francis Group, Boca Raton, London, New York, 327-342 pp.

Frankenberg, D., S. L. Coles \& R. E. Johannes (1967) The potential trophic significance of Callianassa major fecal pellets. Limnology and Oceanography, 12, 113-120.

Gurney, R. (1938) Larvae of Decapod Crustacea. Part V. Nephropsidea and Thalassinidea. Discovery Reports, 17, 293-344. 
Gurney, R. (1942) Larvae of decapod Crustacea. Ray Society, London.

Hall, T. A. (2005) BioEdit version 7.1.3. Biological sequence alignment editor for windows 95/98/NT/2000/XP. Disponível em: http://www.mbio.ncsu.edu/BioEdit/bioedit.html. Acesso em 15 de jul. 2012.

Heard R. W., R. A. King, D. M. Knott, B. P. Thoma \& S. Thornton-DeVictor (2007) A guide to the Thalassinidea (Crustacea: Malacostraca: Decapoda) of the South Atlantic Bight. NOAA Professional Paper NMFS 8. 30 p.

Kohlsdorf, T. \& G.P. Wagner (2006) Evidence for the reversibility of digit loss: a phylogenetic study of Limb evolution in Bachia (Gymnophthalmidae: Squamata). Evolution, 60, 1896-1912.

Le Loeuff, P. \& A. Intès (1974) Les Thalassinidea (Crustacea, Decapoda) du Golfe de Guinée systématique - écologie. Cahiers de l'Office de Recherches Scientifiques et Techniques Outre-Mer, série Océanographique, 12, 17-69.

de Man, J. G. (1928a) A contribution to the knowledge of twenty-two species and three varieties of the genus Callianassa Leach. Capita Zoologica, 2, $1-56$.

de Man, J. G. (1928b) The Decapoda of the Siboga-Expedition. Part 7. The Thalassinidae and Callianassidae collected by the Siboga-Expedition with some remarks on the Laomediidae. Siboga Expéditie, 39, 1-187.

Manning, R.B. (1975) Two methods for collecting decapods in shallow water. Crustaceana, 29, 317-319.

Manning, R. B. \& D. L. Felder (1986) The status of the callianassid genus Callichirus Stimpson, 1866 (Crustacea: Decapoda: Thalassinidea). Proceedings of the Biological Society of Washington, 99, 437-443.

Manning, R. B. \& D. L. Felder (1991) Revision of the American Callianassidae (Crustacea: Decapoda: Thalassinidea). Proceedings of the Biological Society of Washington, 104, 764-792.

Mantelatto, F. L., R. Robles, R. Biagi \& D. L. Felder (2006) Molecular analysis of the taxonomic and distributional statu s for the crab genera Loxopagurus Forest, 1964, and Isocheles Stimpson, 1858 (Decapoda, Anomura, Diogenidae). Zoosystema, 28, 495-506.

Mantelatto, F. L., R. Robles \& D. L. Felder (2007) Molecular phylogeny of the crab genus Portunus (Crustacea, Portunidae) from the western Atlantic. Zoological Journal of the Linnean Society, 150, 211-220.

Mantelatto, F. L., M. A. Scelzo \& C. C. Tudge (2009) Morphological and morphometric appraisal of the spermatophore of the southern hermit 
crab Isocheles sawayai Forest and Saint Laurent, 1968 (Anomura: Diogenidae), with comments on gonopores in both sexes. Zoologischer Anzeiger, 248, 1-8.

Matioli, S.R. (2001) Biologia Molecular e Evolução. Holos Editora, Ribeirão Preto.

Melo, G. A. S. (1999) Manual de identificação dos Crustacea Decapoda do litoral Brasileiro: Anomura, Thalassinidea, Palinuridea, Astacidea. Editora Plêiade/FAPESP, São Paulo.

Ortmann, A. E. (1893) Decapoden und Schizopoden. Ergebnisse der PlanktonExpedition der Humbolt-Stiftung im Atlantischen Ozean, November 1889, $2,1-120$.

Peiró, D. F. (2008) Ecologia do caranguejo Austinixa aidae (Righi, 1967) (Crustacea: Brachyura: Pinnotheridae) de uma praia arenosa do litoral Norte do Estado de São Paulo. Tese de mestrado. Faculdade de Filosofia Ciências e Letras de Ribeirão Preto da Universidade de São Paulo, Ribeirão Preto.

Peiró, D. F. \& F. L. Mantelatto (2011) Population dynamics of the pea crab Austinixa aidae (Brachyura, Pinnotheridae): a symbiotic of the ghost shrimp Callichirus major (Thalassinidea, Callianassidae) from the southwestern Atlantic. Iheringia, Série Zoologia, 101, 5-14.

Peiró, D. F., P. R. Pezzuto \& F. L. Mantelatto (2011) Relative growth and sexual dimorphism of Austinixa aidae (Brachyura: Pinnotheridae): a symbiont of the ghost shrimp Callichirus major from the southwestern Atlantic. Latin American Journal of Aquatic Research, 39, 261-270.

Peiró, D. F., J.A Baeza, \& F. L. Mantelatto. (2012) Host-use pattern and sexual dimorphism reveals the mating system of the symbiotic pea crab Austinixa aidae (Crustacea: Brachyura: Pinnotheridae). Journal of the Marine Biological Association of the United Kingdom, DOI $10.1017 /$ S0025315412000720

Pileggi, L. A. G. (2009) Sistemática filogenética dos camarões do gênero Macrobrachium Bate, 1868 do Brasil: análises morfológicas e moleculares. Tese de Doutorado. Faculdade de Filosofia, Ciências e Letras de Ribeirão Preto, Universidade de São Paulo, Ribeirão Preto.

Pileggi, L. A. \& F. L. Mantelatto (2010) Molecular phylogeny of the freshwater prawn genus Macrobrachium (Decapoda, Palaemonidae), with emphasis on the relationships among selected American species. Invertebrate Systematics, 24, 194-208.

Poore, G. C. B. \& D. J. G. Griffin (1979) The Thalassinidea (Crustacea: Decapoda) of Australia. Records of the Australian Museum, 32, 217-321.

Robles, R., C. C. Tudge, P. C. Dworschak, G. C. B. Poore \& D. L. Felder (2009) Molecular phylogeny of the Thalassinidea based on nuclear and 
mitochondrial genes. In: Martin, J. W., K. A. Crandall \& D. L. Felder (Eds.). Decapod Crustacean Phylogenetics. CRC Press, Taylor \& Francis Group, Boca Raton, London, New York, 309-326 pp.

Rodrigues, S. A. (1966) Estudos sobre Callianassa: Sistemática, Biologia e Anatomia. Tese de Doutorado. Faculdade de Filosofia Ciências e Letras da Universidade de São Paulo, São Paulo.

Rodrigues, S. A. (1971) Mud shrimps of the genus Callianassa Leach from the Brazilian coast (Crustacea, Decapoda). Arquivos de Zoologia, 20, 191223.

Rodrigues, S. A. (1976) Sobre a reprodução, embriologia e desenvolvimento larval de Callichirus major Say, 1818 (Crustacea, Decapoda Thalassinidea). Boletim de Zoologia Universidade de São Paulo, 1, 85104.

Rodrigues, S. A. (1985) Sobre o crescimento relativo de Callichirus major (Say, 1818) (Crustacea, Decapoda, Thalassinidea). Boletim de Zoologia Universidade de São Paulo, 9, 195-211.

Rodrigues, S. A. \& R. M. Shimizu (1997) Autoecologia de Callichirus major (Say, 1818). Oecologia Brasiliensis, 3, 155-170.

Saint Laurent, M. d. (1973) Sur la systématique et la phylogénie des Thalassinidea: définition des familles des Callianassidae et des Upogebiidae et diagnose de cina genres nouveaux (Crustacea Decapoda). Comptes rendus hebdomadaires des séances de l'Académie des sciences, série D, 277, 513-516.

Saint Laurent, M. d. (1979a) Sur la classification et la phylogénie des Thalassinides: définitions de la superfamille des Axioidea, de la sousfamille des Thomassiniinae et de deux genres nouveaux (Crustacea Decapoda). Comptes rendus hebdomadaires des séances de l'Académie des sciences, série D, 288, 1395-1397.

Saint Laurent, M. d. (1979b) Vers une nouvelle classification des Crustacés Décapodes Reptantia. Bulletin de l'Office National des Pêches République Tunisienne, Ministere de l'Agriculture, 3, 15-31.

Saint Laurent, M. d. \& P. Le Loeuff (1979) Campagnes de la Calypso au large des côtes Atlantiques Africaines (1956 et 1959) (suite) 22. Crustacés Décapodes Thalassinidea. I. Upogebiidae et Callianassidae. Résultats Scientifiques des Campagnes de la Calypso, 11, 29-101.

Sakai, K. (1999) Synopsis of the family Callianassidae, with keys to subfamilies, genera and species, and the description of new taxa (Crustacea: Decapoda: Thalassinidea). Zoologische Verhandelingen, 326, 1-152. 
Sakai, K. (2002) Callianassidae (Decapoda, Thalassinidea) in the Andaman Sea, Thailand. Phuket Marine Biological Center Special Publication, 23, 461532.

Sakai, K. (2005a) The diphyletic nature of the infraorder Thalassinidea (Decapoda, Pleocyemata) as derived from the morphology of the gastric mill. Crustaceana, 77, 1117-1130.

Sakai, K. (2005b) Callianassoidea of the world (Decapoda: Thalassinidea). Crustaceana Monographs, 4, 1-200.

Sakai, K. \& T. Sawada (2005) The taxa of the infraorders Astacidea, Thalassinidea, Palinura, and Anomura (Decapoda, Pleocyemata) classified by the form of the prepyloric ossicle. Crustaceana, 78, 13531368.

Sambrook, J., E. F. Fritsch \& T. Maniatis (1989) In vitro amplification of DNA by the Polymerase Chain Reaction. In: Sambrook, J., E. F. Fritsch \& T. Maniatis. Molecular cloning: a laboratory manual. vol. 2. $2^{a}$ ed. Cold Spring Harbor Laboratory Press, New York, 14.1-14.35 pp.

Say, T. (1817-1818) An account of the Crustacea of the United States. Journal of the Academy of Natural Sciences, Philadelphia, 1, 57-63, 65-80 (plate 4), 97-101, 155-160, 161-169, 235-253, 313-319, 374-380, 381-401, 423-441.

Schmitt, W. L. (1935) Mud shrimps of the Atlantic coast of North America. Smithsonian Miscellaneous Contributions, 93, 1-21.

Schubart, C. D., J. E. Neigel \& D. L. Felder (2000a) Use of the mitochondrial 165 rRNA gene for phylogenetic and population studies of Crustacea. Crustacean Issues, 12, 817-830.

Schubart, C. D., J. A. Cuesta, R. Diesel \& D. L. Felder (2000b) Molecular phylogeny, taxonomy, and evolution of nonmarine lineages within the American grapsoid crabs (Crustacea: Brachyura). Molecular Phylogenetics and Evolution, 15, 179-190.

Schubart, C. D, J. A. Cuesta \& D. L. Felder (2002) Glyptograpsidae, a new brachyuran family from Central America: larval and adult morphology, and a molecular phylogeny of the Grapsoidea. Journal of Crustacean Biology, 22, 28-44.

Skilleter, G. A., Y. Zharikov, B. Cameron \& D. P. McPhee (2005) Effects of harvesting callianassid (ghost) shrimps on subtropical benthic communities. Journal of Experimental Marine Biology and Ecology, 320, 133-158.

Souza, J. R. B. \& C. A. Borzone (2003) A extração de corrupto, Callichirus major (Say) (Crustacea, Thalassinidea), para uso como isca em praias do litoral do Paraná: as populações exploradas. Revista Brasileira de Zoologia, 20, 625-630. 
Staton, J. L. \& D. L. Felder (1995) Genetic variation in populations of the ghost shrimp genus Callichirus (Crustacea: Decapoda: Thalassinoidea) in the western Atlantic and Gulf of Mexico. Bulletin of Marine Science, 56, 523536.

Stimpson, W. (1866) Descriptions of new genera and species of Macrurous Crustacea from the coasts of North America. Proceedings of the Chicago Academy of Sciences, 1, 46-48.

Strasser, K. M. \& D. L. Felder (1999a) Larval development of two populations of the ghost shrimp Callichirus major (Decapoda: Thalassinidea) under laboratory conditions. Journal of Crustacean Biology, 19, 844-878.

Strasser, K. M. \& D. L. Felder (1999b) Settlement in an Atlantic coast population of the ghost shrimp Callichirus major (Crustacea: Decapoda: Thalassinidea). Marine Ecology Progress Series, 183, 217-225.

Suchanek, T. H. (1983) Control of seagrass communities and sediment distribution by Callianassa (Crustacea, Thalassinidea) bioturbation. Journal of Marine Research, 41, 281-298.

Suchanek, T. H. \& P. L. Colin (1986) Rates and effects fo bioturbation by invertebrates and fishes at Enewetak and Bikini Atolls. Bulletin of Marine Science, 38, 25-34.

Suchanek, T. H., P. L. Colin, G. M. McMurtry \& C. S. Suchanek (1986) Bioturbation and redistribution of sediment radionuclides in Enewetak Atoll lagoon by callianassid shrimp: biological aspects. Bulletin of Marine Science, 38, 144-154.

Torati, L. S. (2009). Revisão taxonômica das espécies brasileiras de Potimirin Holtuis, 1954 e filogenia do grupo baseado em dados moleculares. Dissertação de mestrado. Faculdade de Filosofia Ciências e Letras de Ribeirão Preto da Universidade de São Paulo, Ribeirão Preto.

Tsang, L. M., F.-J. Lin, K. H. Chu \& T.-Y. Chan (2008a) Phylogeny of Thalassinidea (Crustacea, Decapoda) inferred from three rDNA sequences: implications for morphological evolution and superfamily classification. Journal of Zoological Systematics and Evolutionary Research, 46, 216223.

Tsang, L. M., K. Y. Ma, S. T. Ahyong, T.-Y. Chan \& K. H. Chu (2008b) Phylogeny of Decapoda using two nuclear protein-coding genes: origin and evolution of the Reptantia. Molecular Phylogenetics and Evolution, 48, 359-368.

Vergamini, F. G., L. G. Pileggi \& F. L. Mantelatto (2011) Genetic variability of the Amazon River prawn Macrobrachium amazonicum (Decapoda, Caridea, Palaemonidae). Contribuitions to Zoology, 80, 67-83. 
Waslenchuk, D. G., E. A. Matson, R. N. Zajac, F. C. Dobbs \& J. M. Tramontano (1983) Geochemistry of burrow waters vented by a bioturbating shrimp in Bermudian waters. Marine Biology, 72, 219-225.

Webb, A. P. \& B. D. Eyre (2004) Effects of natural populations of burrowing thalassinidean shrimp on sediment irrigation, benthic metabolism, nutrient fluxes and denitrification. Marine Ecology Progress Series, 268, 20-220.

Wynberg, R. P. \& G. M. Branch (1991) An assessment of bait-collecting for Callianassa kraussi Stebbing in Langebaan Lagoon, western Cape, and of associated avian predation. South African Journal of Marine Science, $11,141-152$.

Wynberg, R. P. \& G. M. Branch (1994) Disturbance associated with baitcollection for sandprawns (Callianassa kraussi) and mudprawns (Upogebia africana) - long-term effects on the biota of intertidal sandflats. Journal of Marine Research, 52, 523-558.

Ziebis, W., S. Forster, M. Huettel \& B. B. Jorgensen (1996) Complex burrows of the mud shrimp Callianassa truncata and their geochemical impact in the sea bed. Nature, 382, 619-622. 


\section{Capítulo 1}

Designation of Callichirus macrotelsonis (Ortmann, 1893) comb. nov. as the "Brazilian species" of Callichirus major complex (Decapoda: Axiidea: Callianassidae) on the basis of morphological and molecular data

Artigo a ser submetido à revista Zootaxa, 2012 
Designation of Callichirus macrotelsonis (Ortmann, 1893) comb. nov. as the

"Brazilian species" of Callichirus major complex (Decapoda: Axiidea:

Callianassidae) on the basis of morphological and molecular data

Douglas F. Peiró ', Rafael Robles', Darryl L. Felder² \& Fernando L. Mantelatto'

1 Laboratory of Bioecology and Crustacean Systematics (LBSC), Department of Biology, Faculty of Philosophy, Science and Letters of Ribeirão Preto (FFCLRP), University of São Paulo (USP), Postgraduate Program in Comparative Biology, Av. Bandeirantes 3900, 14040-901, Ribeirão Preto (SP), Brazil.

2 Department of Biology, Laboratory for Crustacean Research, University of Lovisiana at Lafayette, Lafayette, LA 70504-2451, USA 


\section{Abstract}

The name Callichirus major sensu lato is widely utilized to identify economically and ecologically important ghost shrimps distributed widely along western Atlantic coastlines. Members of Callichirus major complex share eyes ending in short terminal spines or blunt angles. However, taxonomic status of C. major s. I. is somewhat doubtful, in part due to the very large geographic distribution and to the close morphological similarities shared among species/populations. The objective of this study was to examine morphological and molecular evidences for potential separation of Brazilian populations from the C. major complex. We analyzed different populations from Brazilian coastlines, comparing them morphologically and molecularly (16S mtDNA) with individuals of the complex from other regions. As results, the Callichirus major complex can be separated into at least four species. Here we propose that North American populations retain the name Callichirus major while Brazilian populations are hereafter recognized under an existing species name previously assigned to a marine larva of uncertain affinities. As some years ago called to our attention by the late Dr. Sergio A. Rodrigues, a species originally described by Ortmann (1893) as Anomalocaris macrotelsonis closely matches the fourth larval stage of the Brazilian Callichirus, which leads us to adopt the new combination, Callichirus macrotelsonis to name it.

Key words: Callichirinae, ghost shrimp, sandy beach, systematics, taxonomy. 


\section{Introduction}

Callichirus Stimpson, 1866 (Axiidea, Callianassidae) has been treated in different meanings [e.g. a subgenus or a synonym of Callianassa; see Manning \& Felder, (1986)] until C. major sensu stricto have been designated the type species of the genus by de Saint Laurent (1973). However, only 13 years latter Callichirus was definitively recognized as such after the taxonomic review by Manning \& Felder (1986).

Callichirus major s. s. was originally described by Say (1818) as Callianassa major, from east Florida and southern states of United States of America. However, the name C. major sensu lato was widely utilized to identify economically and ecologically important ghost shrimps distributed widely along western Atlantic coastlines. The distribution is from State of North Carolina/USA, passing through Gulf of Mexico and Caribbean Sea, to State of Santa Catarina in Brazil (Staton \& Felder, 1995; Melo, 1999; Abrunhosa et al. 2008). It occurs on open, dissipative and flat sandy beaches (Botter-Carvalho et al. 2002; 2007). Moreover, shows a cryptic habit and lives individually in deep galleries primarily in the intertidal zone, but also in shallow $(2-3 \mathrm{~m})$ subtidal depths (Frankenberg et al. 1967; Rodrigues \& Shimizu, 1997; Heard et al. 2007).

The taxonomic status of C. major s. I. is somewhat doubtful, in part due to the very high geographic distribution, to close morphological similarities shared among species/populations and a lack of taxonomic study associating both circumstances. C. major s. I. was re-described by Rodrigues (1971), from southeast Brazil specimens - primarily from Santos, State of São Paulo (Rodrigues, 1985). Morphological differences between Brazilian and North American populations were first reported by relative growth studies (just of the chelar propodus) from almost 30 years ago (Rodrigues, 1985). However, that 
paper was not conclusive in terms of taxonomic nomenclature of the species. Later, genetic structure among populations from the Atlantic coast of North America, from the Gulf of Mexico, and from the Caribbean coast of Colombia was subsequently reported, suggesting C. major, as presently treated, represents a complex of very close species (Staton \& Felder, 1995).

In 1976, Rodrigues published a paper about embryology and larval descriptions (stages 1-3) of C. major s. I. from Brazil. Additionally, morphological and behavioral differences in larval stages were reported between Atlantic coast and Gulf of Mexico populations in North America years after by Strasser \& Felder (1999a, 1999b). In these last two papers, the "Brazilian C. major" population was treated as closer to the North American populations, but referred as sub-species or a possible different species from the C. major s. s. from United States.

Recently, sampling on Pacific coastlines of the Americas (specifically Mexico), Felder \& Robles (2009) have noted by genetic studies the presence of at least one species close to C. major. Furthermore, sampling in the Pacific coastlines of Costa Rica, some of us (D.F. Peiró and F.M. Mantelatto) have produced independently more samples of that not yet described eastern Pacific species belonging to the $C$. major complex. These collections add a new intriguing distribution to this complex (so far, unique to the east of Americas - but now in Pacific Ocean waters) and are being treated on next steps on the series of papers about the C. major complex by us.

As some years ago called to our attention by the late Dr. Sergio A. Rodrigues, and by digging the literature about Callichirinae species, we found an important clue to determine the status of the "Brazilian C. major". In his paper about larval development of Callianassa (now Sergio) mirim, Rodrigues 
(1984) referred about a previously assigned marine larva of uncertain affinities; a species originally described as Anomalocaris macrotelsonis Ortmann, 1893 who closely matches the fourth larval stage of the Brazilian C. major [stage not described in his paper about larval description and development of C. major (Rodrigues, 1976)]. Analyzing the larval description and drawings of $A$. macrotelsonis and comparing with the descriptions of the first to third larval stages of the "Brazilian C. major" described by Rodrigues (1976), we were leaded to consider these as the same species.

Spite of the longtime discussion about differences among Callichirus major s. I. populations, the taxonomic status of this complex has experienced no significant changes related to unveil the validity of the different species. We present herein a molecular comparison of different species/populations from Atlantic Ocean, Gulf of Mexico, Caribbean Sea and also Pacific Ocean. The main objective of this study was to examine morphological and molecular evidence for potentially separation Brazilian populations from the remainder of the C. major complex using a new combination to name it. 


\section{Material and Methods}

Specimens analysis. Material for this study was in part collected from the intertidal zone of sandy beaches by suction from the burrow with a "yabby pump" (Hailstone \& Stephenson, 1961; Rodrigues, 1966; Manning, 1975). The collections were made at different points of Callichirus major's sensu lato (complex) geographic distribution, and deposited at Crustacean Collection of the Departamento de Biologia (CCDB) da Faculdade de Filosofia Ciências e Letras de Ribeirão Preto, Universidade de São Paulo at Ribeirão Preto, State of São Paulo, Brazil. In addition, several analyzed specimens were donated from colleagues, obtained as a loan or analyzed at different carcinological collections: Carcinological Collection of the Museu de Zoologia da Universidade de São Paulo (MZUSP), São Paulo, São Paulo, Brazil; Museo de Zoología of the Universidad de Costa Rica (MZUCR), San Pedro, San José, Costa Rica; University of Louisiana at Lafayette's Zoological Collections (ULLZ), Lafayette, Louisiana, EUA; Senckenberg Forschungsinstitut und Naturmuseum (Senckenberg-Mus), Frankfurt am Main, Germany; Carcinological Collection of the Departamento de Oceanografia da Universidade Federal de Pernambuco (CCDO/UFPE), Recife, Pernambuco, Brazil; Carcinological Collection of the Museu de Zoologia da Universidade Estadual de Santa Cruz (UESC), Ilhéus, Bahia, Brazil (Table 1). 
Table 1. Callichirus species used for the phylogenetic reconstructions with respective site of collection and reference, museum catalogue number, and isolate, sex and genetic database accession number (GenBank).

\begin{tabular}{|c|c|c|c|}
\hline Species & Collection site, Ocean/Sea, Reference & Catalogue no. & $\begin{array}{l}\text { Isolate, sex, } \\
\text { GenBank } \\
\text { accession no. }\end{array}$ \\
\hline $\begin{array}{l}\text { Callichirus macrotelsonis } \\
\text { (Ortmann, 1893) }\end{array}$ & Bragança, Pará, Brazil, Atlantic & CCDB 2864 & $\begin{array}{l}019 \mathrm{JX878460} \\
02+\mathrm{JX878461}\end{array}$ \\
\hline C. macrotelsonis & Luis Correia, Piauí, Brazil, Atlantic & CCDB 2973 & $\begin{array}{l}03 \hat{\jmath} \mathrm{JX} 878464 \\
049 \text { JX878465 }\end{array}$ \\
\hline C. macrotelsonis & Maxaranguape, Rio Grande do Norte, Brazil, Atlantic & CCDB 429 & $\begin{array}{l}05 \hat{\jmath} \mathrm{JX} 878473 \\
06 \hat{\jmath} \mathrm{JX} 878474\end{array}$ \\
\hline C. macrotelsonis & Acaú, Paraíba, Brazil, Atlantic & CCDO/UFPE 8391 & 07ふ̋ JX878468 \\
\hline C. macrotelsonis & Jaboatão dos Guararapes, Pernambuco, Brazil, Atlantic & UESC 1531 & 08ßึ JX878469 \\
\hline C. macrotelsonis & $\begin{array}{l}\text { Praia dos Morros, Passo do Camaragibe, Alagoas, Brazil, } \\
\text { Atlantic }\end{array}$ & CCDB 2678 & $\begin{array}{l}09 \hat{\jmath} \mathrm{JX} \times 878453 \\
10 \hat{\jmath} \mathrm{J} X 878454\end{array}$ \\
\hline C. macrotelsonis & Praia dos Milionários, Ilhéus, Bahia, Brazil, Atlantic & CCDB 3102 & $11 \hat{\jmath} \mathrm{JX878475}$ \\
\hline C. macrotelsonis & Praia do Perequê-açu, Ubatuba, São Paulo, Brazil, Atlantic & CCDB 2938 & $\begin{array}{l}12 \hat{\jmath} \mathrm{JX} 878477 \\
13 \hat{\mathrm{o} J X 878478}\end{array}$ \\
\hline C. macrotelsonis & Praia do Lazaro, Ubatuba, São Paulo, Brazil, Atlantic & CCDB 2661 & $\begin{array}{l}14 \hat{\jmath} \mathrm{JX} 878449 \\
15 \hat{\jmath} \mathrm{JX} 878450\end{array}$ \\
\hline C. macrotelsonis & Praia Barra do Saí, São Sebastião, São Paulo, Brazil, Atlantic & MZUSP 14557 & $16 \hat{\jmath} \mathrm{JX878470}$ \\
\hline C. macrotelsonis & $\begin{array}{l}\text { Praia de Baraqueçaba, São Sebastião, São Paulo, Brazil, } \\
\text { Atlantic }\end{array}$ & CCDB 2677 & $\begin{array}{l}17 \hat{\jmath} \mathrm{JX} 878451 \\
18 \hat{\jmath} \mathrm{JX} 878452\end{array}$ \\
\hline C. macrotelsonis & Ilha comprida, São Paulo, Brazil, Atlantic & CCDB 3184 & $19 \hat{\jmath} \mathrm{JX} 878476$ \\
\hline C. macrotelsonis & Praia Barra do Saí, Itapoá, Santa Catarina, Brazil, Atlantic & CCDB 2184 & $\begin{array}{l}20 ? \mathrm{JX} 878466 \\
210 \text { JX878467 }\end{array}$ \\
\hline C. macrotelsonis & Balneário Camboriú, Santa Catarina, Brazil, Atlantic & CCDB 2868 & $\begin{array}{l}22 \hat{\jmath} \mathrm{J} X 878462 \\
23 \hat{\jmath} \mathrm{J} X 878463\end{array}$ \\
\hline C. macrotelsonis & $\begin{array}{l}\text { Perequê-açu, Ubatuba, São Paulo, Brazil, Atlantic; Felder \& } \\
\text { Robles, } 2009\end{array}$ & ULLZ 6055 & EU882917 \\
\hline C. macrotelsonis & $\begin{array}{l}\text { Perequê-açu, Ubatuba São Paulo, Brazil, Atlantic; Felder \& } \\
\text { Robles, } 2009\end{array}$ & ULLZ 6056 & EU882918 \\
\hline $\begin{array}{l}\text { Callichirus major } \\
\text { (Say, 1818) }\end{array}$ & EUA; Porter et al. 2005 & KAC1864 & DQ079707 \\
\hline C. major & $\begin{array}{l}\text { Isles Dermieres, Louisiana, EUA, Gulf of Mexic; Morrison et al. } \\
2002\end{array}$ & MV J39044 & AF436041 \\
\hline Callichirus aff. major sp. 1 & Playa Curu, Paquera, Puntarenas, Costa Rica, Pacific & CCDB 2869 & 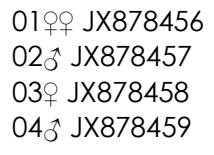 \\
\hline C. aff. major sp. 1 & Baja California, Mexico, Pacific; Felder \& Robles, 2009 & ULLZ 4163 & EU882922 \\
\hline Callichirus aff. major sp. 2 & Cartagena, Colombia, Caribbean & CCDB 3425 & $01 \hat{\jmath} \mathrm{JX878471}$ \\
\hline C. aff major sp. 2 & Cartagena, Colombia, Caribbean & CCDB 3426 & 02ふૈ JX878472 \\
\hline $\begin{array}{l}\text { Callichirus seilacheri } \\
\text { (Bott, 1955) }\end{array}$ & Baja California, Mexico, Pacific; Felder \& Robles, 2009 & ULLZ 6054 & EU882920 \\
\hline C. seilacheri & Nicaragua, Pacific; Felder \& Robles, 2009 & ULLZ 6053 & EU882921 \\
\hline C. seilacheri & Playa Curu, Paquera, Puntarenas, Costa Rica, Pacific & CCDB 561 & $010^{\hat{~}} \mathrm{JX} \times 878455$ \\
\hline $\begin{array}{l}\text { Callichirus islagrande } \\
\text { (Schmitt, 1935) }\end{array}$ & Mississippi, USA, Gulf of Mexico; Felder \& Robles, 2009 & ULLZ 6052 & EU882916 \\
\hline
\end{tabular}

?: sex no determined 
Molecular analysis. All analyses (DNA extraction, amplification and sequencing) were carried out using at least two specimens (when possible) from each locality and species (as show in the molecular tree), in order to reduce misidentifications by variability. Genetic vouchers were obtained and deposited at CCDB and additional nucleotide sequences were obtained from GenBank to complete the set of data for analysis (Table 1). DNA extraction, amplification and sequencing protocols followed Schubart et al. (2000a) with modifications as in Mantelatto et al. (2006, 2007 and 2009). Total genomic DNA was extracted from the muscle tissue (by minimally destructive methods) of the chelipeds or pleopods. Muscle was ground and then incubated until been totally diluted $(\sim 12-36 \mathrm{~h})$ in $600 \mathrm{ml}$ of lysis buffer plus $200 \mu \mathrm{L}$ proteinase $\mathrm{K}$ (500 $\mu \mathrm{g} / \mathrm{mL}$ ) at $55^{\circ} \mathrm{C}$; protein was separated by addition of $200 \mathrm{ml}$ of $7.5 \mathrm{M}$ ammonium acetate before centrifugation. DNA was precipitated by addition of $700 \mathrm{ml}$ of cold absolute isopropanol followed by centrifugation; the resultant pellet was washed with $15 \mu \mathrm{L}$ of $70 \%$ ethanol, dried and re-suspended in $20 \mu \mathrm{L}$ of TE buffer. The 16S mtDNA gene was amplified from diluted DNA by means of a polymerase chain reaction (PCR) in a Thermo ${ }^{\circledR}$ Thermal Cycler PXE 0.2 and Applied Biosystems ${ }^{\circledR}$ Veriti 96 Well Thermal Clycler (thermal cycles: initial denaturing for $5^{\prime}$ at $95^{\circ} \mathrm{C}$; annealing for 40 cycles: $45^{\prime \prime}$ at $95^{\circ} \mathrm{C}, 45^{\prime \prime}$ at $48^{\circ} \mathrm{C}$, $1^{\prime}$ at $72^{\circ} \mathrm{C}$; final extension of $3^{\prime}$ at $72^{\circ} \mathrm{C}$ ) with universal $16 \mathrm{~S}$ mtDNA primers (Schubart et al. 2000a, b; Schubart et al. 2002): 16SH2 (5'-AGATAGAAACCAACCTGG-3'); 16SL2 (5'-TGCCTGTTTATCAAAAACAT-3'). PCR products were purified using Sure Clean ${ }^{\circledR}$ protocol and sequenced with the ABI Big Dye ${ }^{\circledR}$ Terminator Mix (Applied Biosystems, Carlsbad, CA) in an ABI Prism 3100 Genetic Analyzer ${ }^{\circledR}$ (Applied Biosystems automated sequencer) following Applied Biosystems protocols. 
Phylogenetic molecular analysis. All sequences were confirmed by sequencing both strands and a consensus sequence was obtained using the computational program BIOEDIT 7.0.5 (Hall, 2005). All consensus sequences were checked at BLAST (The Basic Local Alignment Search Tool http://blast.ncbi.nlm.nih.gov) to confirm the identities. The nucleotide sequences were aligned using Muscle (Multiple Sequence Comparison by LogExpectation) (Edgar, 2004a; 2004b) on European Bioinformatics Institute (EBI) website (http://www.ebi.ac.uk/Tools/msa/muscle).

The evolutionary history hypothesis of the C. major complex was inferred using Maximum Likelihood (ML) method in order to determine the intern relationships between species. To test the monophyly on C. major complex, Callichirus islagrande (Schmitt, 1935) was used as out-group.

Data were grouped to create a ML hypothesis using RAXML (Randomized Axelerated Maximum Likelihood) (Stamatakis, 2006); a program for Maximum Likelihood-based inference of phylogenetic trees on CIPRES Science Gateway (Cyberinfrastructure for Phylogenetic Research; http://www.phylo.org). This method assumes that each position (character) evolves independently and requires a probabilistic model of evolution of the characters that is calculated for various topologies by varying the size of the branches for taxa. This procedure is repeated for all possible trees and provide the final tree with greater value of ML (Schneider, 2007). In other words, this method infer an evolutionary tree by the search of the tree that maximize the probability of observation of data, or, find the tree with major probability of occurrence, considering parameters like substitution rates and frequency of bases, from a chose evolutionary model (Russo et al. 2001; Hall, 2011). The evolutionary model assumed was $G T R+G+I$, in the RAxML. The internal 
consistency of topologies was assessed by bootstrap method (Felsenstein, 1985) with 1000 replicates, and only values above $50 \%$ confidence were presented in the tree.

The sequencing was previously submitted to Gblocks software (Version 0.91b, 2002; Castresana, 2000), that eliminates poorly aligned positions and divergent regions of an alignment. These positions may not be homologous or may have been saturated by multiple substitutions and it is convenient to eliminate them prior to phylogenetic analysis (Castresana, 2000). Although the transition rate being greater than that of transversion, when increases the divergence between the sequences, the transition and transversion ratio may decrease due to saturation. Consequently, there may be loss of phylogenetic information contained in sequences, damaging the analyzes and may not reflect the actual relationship between the taxa (Xia \& Xie, 2001; Schneider,2007). 


\section{Results and Discussion}

\section{Phylogenetic Molecular Analysis Background}

Build upon molecular findings based on sequencing of the 165 mtDNA were established the evolutionary relationship hypothesis of Callianassidae genus Callichirus by Maximum Likelihood analysis. Were obtained and identified partial sequences from 23 individuals of C. macrotelsonis from different populations through Brazilian coastlines, as well as 4 individuals of Callichirus aff. major sp. 1 from Costa Rica, 2 individuals of Callichirus aff. major sp. 2 from Colombia, 1 individual of Callichirus seilacheri from Costa Rica. Other partial sequences of $16 \mathrm{~S} \mathrm{mt}$ gene of Callichiurs species and out-group species used in molecular analysis were obtained from GenBank (Table 1).

The obtained 165 mtDNA sequences varied from 396 to 540 pair of bases (pb). The multiple alignment by Muscle was obtained with a total of 546 positions, excluding primers. The best fit of substitution model, by Akaike criterion of information, were $G T R+G+1$, showing the following parameters: frequency of bases, $A=0.3477, C=0.1833, G=0.1499, T=0.3191$; proportion of invariable sites $=0$

The topology of the tree (Figure 1) showed the monophyletic nature of the C. major complex, with four species (a, b, c and $\mathbf{d}$ ) genetically identifiable along the Americas coastlines, both on East and West side. The molecular phylogenic analysis shown three western Atlantic groups and one eastern Pacific group (all definitely part of has been termed as C. major complex). The first group (a) is compound by the Callichirus major (Say, 1818) sensu strito from North Atlantic and Gulf of Mexico, EUA, (Figure 1a); this group retains the 
original name. C. major s. s., and it is sister group of the others three groups who are also distinctly separable. The second monophyletic group (b) is compound by the "Brazilian C. major s. I.", here renamed by new the combination Callichirus macrotelsonis (Ortmann, 1893) - as described below (Figure 1b). The later group is sister group of the two remaining others. The third group (c) is the Caribbean species - Callichirus aff. major sp. 2 - from Colombia (Figure 1c), the sister group of the fourth (d) and intriguing Callichirus aff. major sp. 1, from Pacific areas of Central America (Costa Rica) and Mexico (Callichirus sp. PMX, from Baja California, reported on Felder \& Robles, 2009) - which was probably separated by the uplift of the Panama Isthmus (Figure 1d).

The variability and conservation in 165 mHDNA gene was very informative considering the phylogenetic relationships in the genus and in the $C$. major complex of species. The maximum likelihood hypothesis corroborate the previous suppositions (Strasser \& Felder, 1999a; 1999b) about a complex of species in North Atlantic, Caribbean Sea and South Atlantic "populations", and Eastern Pacific related species (with close morphological characteristics). As consequence the validation of the "Brazilian species". Besides the original C. major, and the now named C. macrotelsonis (see below), other two, not yet described, were genetically identifiable. One of them cited by Felder \& Robles (2009) (from Pacific North and Central America); and other cited for the first time here, as a distinct species, from Caribbean Sea. Both species are being simultaneously described by us. All species here studied (C. major s. I.) are situated in distinct biogeographic regions (none of them are sympatric), and that is other assumption to corroborate our hypothesis about different species in this complex. 


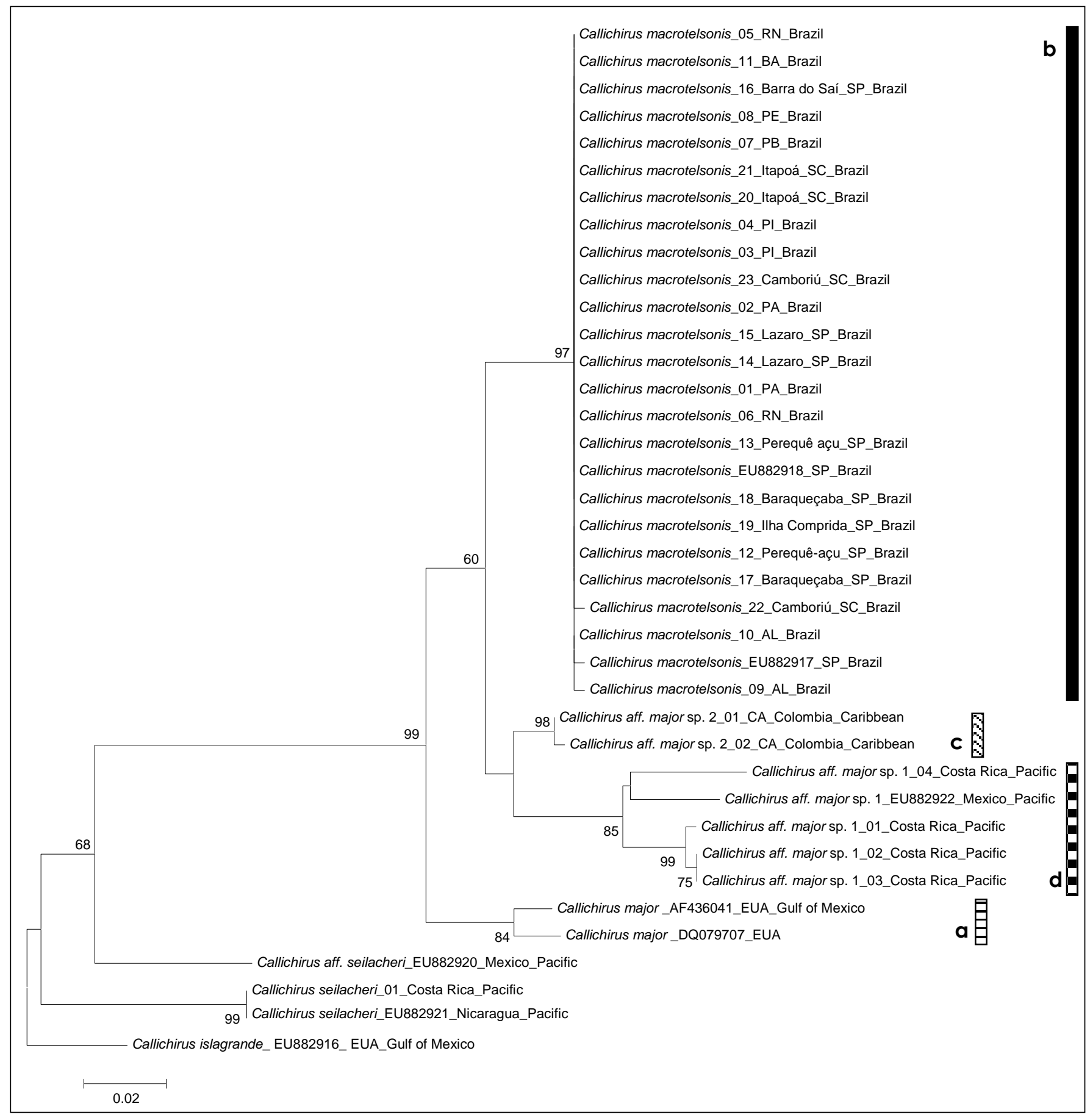

FIGURE 1. Evolutionary hypothesis by Maximum Likelihood analysis of to Callichirus major complex. C. islagrande as out-group, based on sequencing of the 16S mtDNA. Numbers are: $\geq 50$ bootstrap values. a. Callichirus major sensu strito from North America, Atlantic Ocean and Gulf of Mexico; b. Callichirus macrotelsonis (Ortmann, 1893) from Brazilian coast (Atlantic Ocean); c. Callichirus aff. major sp. 2 from Caribbean Sea (Colombia); and d. Callichirus aff. major sp. 1 from eastern Pacific Ocean (Central and North America). 


\section{Systematics (according De Grave et al. 2009)}

Subphylum Crustacea Brunnich, 1772

Order Decapoda Latreille, 1802

Suborder Pleocyemata Burkenroad, 1963

Infraorder Axiidea de Saint Laurent, 1979

Family Callianassidae Dana, 1852

Subfamily Callichirinae Manning \& Felder, 1991

Genus Callichirus Stimpson, 1866

\section{Callichirus major (Say, 1818) sensu lato "complex of species"}

Diagnosis: Members of Callichirus genus that share eyes ending in short terminal spines or blunt angles (C. major and relatives).

Type species: Callichirus major (Say, 1818) p. 238-241. Deposited at "Cabinet of the Academy" of Natural Sciences of Philadelphia (Say, 1818, p. 240); Type probably not extant. Type-locality: "Inhabits the coasts of the southern states and of East Florida" of EUA (Say, 1818, p. 240).

Species included: C. major s. s. (Say, 1818); Callichirus aff major sp. 1 from Pacific Ocean, Central and North America, Costa Rica and (or from/to) Mexico [Felder \& Robles (2009); and present study]; Callichirus aff major sp. 2 from Caribbean Sea, Cartagena, Colombia and Isla Margarita, Venezuela [BlancoRambla (1997), as C. major; and present study]; C. macrotelsonis (Ortmann, 
1893) comb. nov. from Brazilian coastlines (present study). The species map of distribution is show in Figure 2.

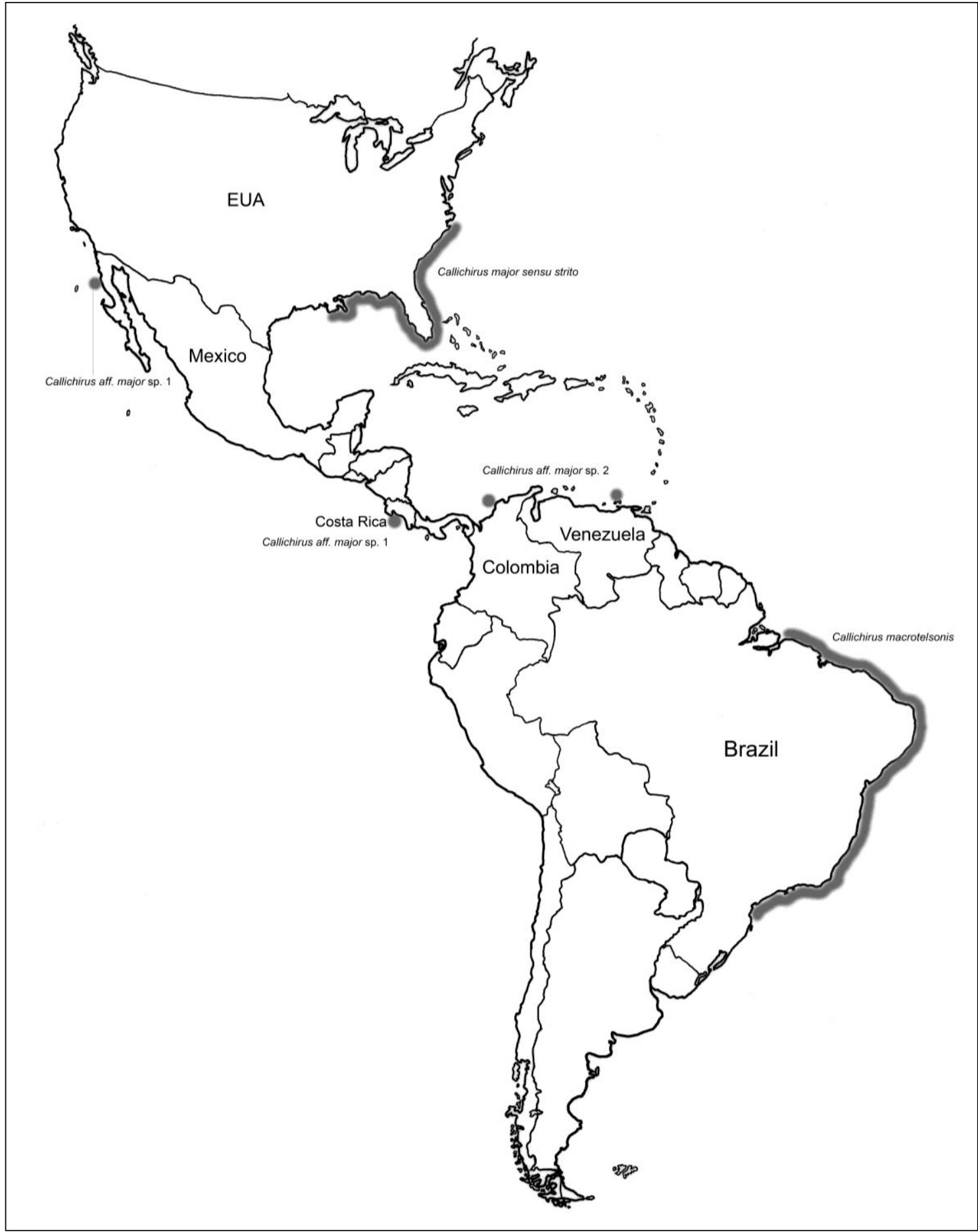

FIGURE 2. Callichirus major complex distribution. Callichirus major (Say, 1818) sensu strito from North America; Callichirus aff. major sp. 1 from Central and North America, eastern Pacific Ocean; Callichirus aff. major sp. 2 from Caribbean Sea; and Callichirus macrotelsonis (Ortmann, 1893) from Brazilian coast. 


\section{Material analyzed:}

Callichirus major (Say 1818) sensu strito: 1 male (15.30), 2 females (14.75; 15.35), ULLZ 13033, W end of Emerald Isl. Cape Charteret, North Carolina, 13.VI.2004, R. Robles, I.T. Rodriguez colls. - 2 males (13.00; 14.00), 2 females (11.50; 13.00; 13.75), ULLZ 4259, Isle of Palms beach (N tip), South Caroline, 23.VIII.2000; C.D. Schubart, J.A. Cuesta colls, (w. P. cristata) - 1 male (11.00), 1 female (11.00), 2 ovígerous females (11.80; 12.30), ULLZ 13037, St. Simons Is., near pass separating from Jekyll Is., Georgia Ocean side (morphological vouch to go with genetic analysis), 17.V.1989, D.L. Felder, A.B. Williams colls. -3 males (11.25; 11.70; 12.00), 1 female (1 1.60), 1 no determined (7.60), ULLZ 4265, Fekyll Island (5 tip), Georgia, 24.VIII.2000, C.D. Schubart, J.A. Cuesta colls. - male (14.00; 17.00), female (14.90; 15.55; 16.00), ULLZ 13040, Savannah Beach, Tybee IS., Chatham Co., S. end of Is, Georgia, 26.VII.1980, R. Heard coll. (compared to LA specimens and judged as conspecific despite the much larger size of these - D.L.F.) - 2 males (12.20; 12.55), 3 females (12.00; 12.55; 13.45), ULLZ 13041, Ft. Pierce Inlet, Florida; 12.V.1989, D.L. Felder, W. Lee colls. -3 males $(6.25 ; 11.80 ; 12.00 ;), 2$ females (10.00; 12.30), ULLZ 9522, 27.VII.2005, Florida, Atlantic, Fort Pierce North or Inlet Dynamite Pt. to Coon Is., USA (FP-05-099), D.L. Felder, H.D.B., R. Robles - 7 males (8.00; 8.50; 9.00; 9.05;9.45; 10.60; 11.00), 1 female (7.60), 2 ovigerous females (10.20; 1 1.00), ULLZ 9659, Fł. Pierce, Coon Island, N of Ft. Pierce Inlet, tidal creek, Florida, Atlantic, USA, 26.VII.2001 - 6 females (9.10; 11.15; 11.50; 11.70; 12.00; 13.20;), ULLZ 13032, Fort Pierce, Florida, USA, VIII.1996, D.L. Felder coll. - 7 female (1 1.25; $11.70 ; 11.90 ; 12.00 ; 12.30 ; 12.55 ; 12.85)$, ULLZ 10229, Indian River Lagoon, between causeways N/S A/A, CSN; -3742, Florida, USA, 16.III.1998, D.L. Felder, C. Schubart et al. colls. - 1 female (10.00), ULLZ 3936, Sebastian Inlet, Florida, USA, 16.VII.1997, K. Strasser coll. - 1 female (12.70), ULLZ 3933, Sebastian Inlet, Florida, 
USA, 17.VII.1997 - 1 female (9.00), ULLZ 3932, Sebastian Inlet, Florida, USA, 13.VI.97 - 1 female (12.00), ULLZ 3934, Sebastian Inlet, Florida, USA, 27.VI.1997 - 1 female (13.00), ULLZ 3930, Sebastian Inlet, Florida, USA, 7.VI.1997.

Callichirus aff. major sp 1: 1 male (8.15), female (7.30), ULLZ 6547, Pta. El Morro, Tumaco, Colombia, Pacific Ocean, 22.XI.1992, S. Nates coll., (remarks: genetic voucher) - 3 males $(9.30 ; 9.65 ; 10.65)$, female (10.41), ovigerous female (10.04), CCDB 2869, Playa Curu, Pacific Coast (Close Paquera), Costa Rica, 11.II.2009, F. L. Mantelatto coll. - 3 males, 6 ovigerous females, CCDB 455, Playa Pochote, Provincia de Guanacaste, Costa Rica, 944'N - 8459'W, 17.01.2009, F.L. Mantelatto coll.

Callichirus aff. major sp 2: 3 males $(8.10 ; 9.35 ; 10.30), 2$ females $(11,15 ; 12.10)$, ULLZ 13044, Cartagena, Colombia, 17-18.IX.1990, D.L. Felder coll. - 1 male (10.75), females (10.40; 10.85; $11.30 ; 11.45$,$) , ULLZ 13039, mud-sand-wave; swash$ zone, Catageña, Colombia, 13.IX.1990, D.L. Felder coll. - 2 males (8.70; 11.40), females (9.70; 11.60), ULLZ 13042, Cartagena, Colombia, 21-22.IX.1990, D.L. Felder coll. - male (10.81), CCDB 3425, Cartagena, Colombia, 17-18.IX.1990, D.L. Felder coll. (from ULLZ 13044) - male (10,72), CCDB 3426, mud-sand-wave; swash zone, Catageña, Colombia, 13.IX.1990, D.L. Felder coll. - 1 male (12.02), CCDB 3727, Punta del Mangle, Isla Margarita, Venezuela, $10^{\circ} 52^{\prime} 276^{\prime \prime N} / 64^{\circ} 03^{\prime} 484^{\prime \prime}$, H. Montoya coll. - 1 male (12,81), CCDB 3728, Punta del Mangle, Isla Margarita, Venezuela, 1052'276"N-6403'484"W, H. Montoya coll.

C. macrotelsonis (Ortmann, 1893) comb. nov.: see details at description. 
Remarks: C. major complex species occur on Americas. On both Atlantic and Pacific Oceans. At the moment, is known at least 1 taxa from Pacific Ocean and 3 from Atlantic Ocean/Caribbean sea, however is possible others cryptic species after further studies.

\section{Callichirus macrotelsonis (Ortmann, 1893) comb. nov.}

(Figures 3, 4, 5, 6 and 7)

Here we propose that North American populations retain the name Callichirus major while Brazilian populations be hereafter recognized under an existing species name previously assigned to a marine larva of uncertain affinities. As some years ago called to our attention by the late Dr. Sergio A. Rodrigues, a species originally described by Ortmann (1893) as Anomalocaris macrotelsonis closely matches the fourth larval stage of the Brazilian Callichirus, which leads us to adopt the new combination, Callichirus macrotelsonis.

\section{Diagnosis: Callichirus macrotelsonis (Ortmann, 1893) comb. nov.}

The rostrum is obtuse and flanked by two obtuse angles near the eyestalks base. The eyestalks are smooth, flattened, and blunt or sharp pointed. They are about 2.5 times as long as wide. They touch each other on the inner margins except at the tip where they diverge. The major pereopod of developed males: the ischium is smooth with a spine at the proximal edge and the lower margin is granulated. The merus has a protruding granulated hook provided with (approximately about 4-5) tufts of hairs on the margin. All the lower margin of the merus is granulated. The propodus has the upper and lower margins 
protrude slightly toward the carpus direction. The propodus has a v-shape protruding in, between the dactylus and fixed finger. The fixed finger tapers gradually toward the tip. It has a big gap and bears tufts of hairs bordering the cutting edge on the external face. The fixed finger is straight at lower margin, sometimes curved at the tip. It has a small ledge on the proximal cutting edge. But not equipped with a strong and truncated tooth. The dactylus is curved and provided with a proximal "blunt" tooth and a smaller on 1/3 distal cutting edge. It has sparse tufts of hairs along the external margin. The dactylus is curved and provided with a proximal "blunt" tooth and a smaller on 1/3 distal cutting edge. It has sparse tufts of hairs along the external margin.

\section{Synonymy}

Anomalocaris macrotelsonis Ortmann, 1893 (establyshed by present study): Ortmann, 1893: 87, 119, plate VI fig. 5, 5d-i, 5k-0, 5z.

Callianassa (Callichirus) major s. I. Say, 1818 (establyshed by Borradaile, 1903): Rodrigues, 1966: 22, fig. 1b-20, 101-110, 126, 135, 137-161, 168; Rodrigues, 1971: 192, fig. 1-20; Coelho \& Ramos, 1972: 161.

Callichirus major s. I. (Say, 1818) (establyshed by Stimpson, 1871): Rodrigues, 1976: 85, fig. 1-35; Rodrigues, 1983: 25, fig. 23-52, 91; Rodrigues, 1985: 195, fig. 1 30; Rodrigues \& Hödl, 1990: 48, fig. 1-2; Borzone \& Souza, 1996: 67; Souza \& Borzone, 1996: 553; Rodrigues \& Shimizu, 1997: 155, fig. 1-2; Shimizu, 1997: 25, fig. II.4; Rodrigues \& Shimizu, 1998; 380; Souza et al. 1998: 151; Coelho, 1999: 50, fig. 34-42; Melo, 1999: 354, fig. 236a-d; Coelho \& Rodrigues, 2001: 1447, fig. 13-21; Botter-Carvalho et al. 2002: 97; Shimizu \& Rosso, 2000: 63; Alves \& Rodrigues, 2003: 408; Souza \& Borzone, 2003: 625; Alves et al. 2005: 784; Botter-Carvalho et al. 2007: 508; Heard et al. 2007: 23. Abrunhosa et al. 2008: 448; Rodrigues, 1984; 
Simão et al. 2006; Peiró \& Mantelatto, 2011: 5; Peiró et al. 2011: 261; Peiró et al. 2012

Sergio guara (Rodrigues, 1971): Nucci \& Melo, 2012: 152.

Distribution: Occurs on South Atlantic Ocean in Brazilian coastlines, from State of Pará (from the South of Amazon River delta) to State of Santa Catarina. No registered at North of Amazon River delta until this moment. Probably it is a biogeographic barrier limiting the species distribution.

Larval description: First to third zoeal stages description by Rodrigues, 1976, p. 85-103, fig. 1-35; Forth zoeal stage description by Ortmann, 1893, p. 87-88, plate VI figs. $5,5 d-i, 5 k-0,5 z$.

Ecological remarks and symbiosis: Rodrigues, 1966; Rodrigues, 1984; Rodrigues \& Hödl, 1990; Borzone \& Souza, 1996; Souza \& Borzone, 1996; Rodrigues \& Shimizu, 1997; Shimizu, 1997; Souza et al. 1998; Botter-Carvalho et al. 2002; Shimizu \& Rosso, 2000; Alves \& Rodrigues, 2003; Souza \& Borzone, 2003; Alves et al. 2005; Simão et al. 2006; Botter-Carvalho et al. 2007; Abrunhosa et al. 2008; Peiró \& Mantelatto, 2011; Peiró et al. 2011; Peiró et al. 2012; Peiró et al. (submitted; Chapter II); Peiró et al. (in press); Peiró \& Mantelatto (in preparation, Chapter III).

Other morphological characters: Rodrigues, 1971; Rodrigues, 1985; Coelho, 1999; Coelho \& Rodrigues, 2001. 
Type locality: Here designed as Perequê-açu Beach, Ubatuba, State of São Paulo, Brazil.

\section{Type material designed}

Carapace oval area length $\mathrm{mm}(\mathrm{CO})$ in parentheses.

Sintypes: - 6 males $(8.25 ; 8.35 ; 9.05 ; 9.45 ; 10.75 ; 13.25)$, 7 females $(9.00 ; 9.45 ; 9.65$; $10.45 ; 11.15 ; 12.15 ; 14.45), 5$ ovigerous females $(12.45 ; 13.25 ; 13.75 ; 13.95 ; 14.15)$, CCDB 0363, Praia do Perequê-açu, Ubatuba, São Paulo, Brazil,

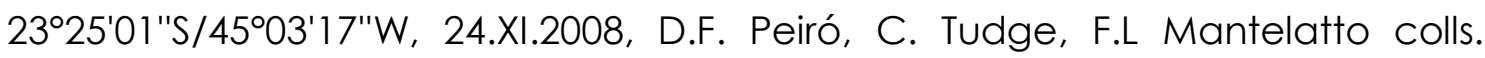
(extrato inferior) - 11 males $(9.95 ; 13.75 ; 10.35 ; 7.25 ; 13.65 ; 9.85 ; 6.55 ; 10.45 ; 10.00$; 9.75), 8 females $(8.75 ; 9.25 ; 9.55 ; 10.00 ; 10.45 ; 10.85), 5$ ovigerous females (10,35; $11,15 ; 13,00 ; 13,85 ; 14,15)$, CCDB 2938, Praia do Perequê-açu, Ubatuba, São

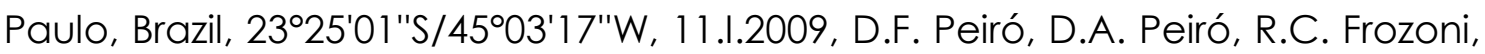
R.R.R. da Silva colls. - 1 male (14.50), CCDB 2938-2, Praia do Perequê-açu,

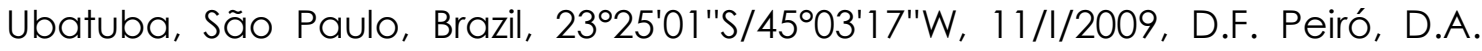
Peiró, R.C. Frozoni, R.R.R. da Silva colls., genetic voucher XDNA-179 isolate 62. Lectotype: - 1 male(14.40), CCDB 2938-3 Praia do Perequê-açu, Ubatuba, São Paulo, Brazil, 2325'01"S/4503'17"W, 11/I/2009, D.F. Peiró, R.C. Frozoni, D.A. Peiró, R.R.R. da Silva colls., genetic voucher XDNA-179 isolate 63.

Non type material examined (from North to South)

- 2 males, 11 females, CCDB 2864, Praia Ajuruteua, Bragança, Pará, Brazil, 0054'14"S/46³7'42"W, 30.VIII.2009, F. Abrunhosa coll. - 6 males, 3 females, CCDB 2973, Praia Luis Correia do Piauí, Luis Correia, Piauí, Brazil, 0251'42"S/41³9'1 1'W, 02.VII.2010, F. Augusto, J.M. Góes colls. - 1 male (9.13), CCDO/UFPE 8391, Acaú, Paraíba, Brazil, 04.VI.1996, - 2 males (12,60; 13.00), 
MZUSP 22367, Praia do Rosado, Rio Grande do Norte, Brazil, 24.XI.2009, Tavares, Pinheiro, Santana, Faria, Braga; colls. "obs: bomba de sucção diurno (tarde), maré baixa; 0500,314'S - 3694,929'W" - 1 male (9.16), UESC 1531, Praia de Piedade, Jaboatão dos Guararapes, Pernambuco, Brazil, 12.IV.2008, A.O. Almeida, V.H. Maia, M.H. Maia colls. - 1 male (8.58), CCDO/UFPE 8388, Venda Grande, Pernanbuco, Brazil, 26.I.1990 - 1 female (9.30), 1 ovigerous female (9.10), CCDO/UFPE 8372, Tamandaré, Pernanbuco, Brazil, 05/02/1989 - 14 male, 19 females, CCDB 2678, Praia dos Morros do Camaragibe, Passo do Camaragibe, Alagoas, Brazil, 09¹9'50"S/35²6'21"W, 08.IV.2009, D.F. Peiró coll. - 1 male (11.15), MZUSP 5738, Praia do Atalaia, Aracajú, Sergipe, Brazil, X.1976, S. Rodrigues coll. - 1 male (11.25), MZUSP 5632, Praia do Atalaia, Aracajú, Sergipe, Brazil, IX.1976, S. Rodrigues coll. - 1 male (10.47), 1 female (10.78), CCDB 3102, Praia dos Milionários, Ilhéus, Bahia, Brazil, 1450'47,3"S/3901'27,7"W, 01.XI.2010, D.F. Peiró coll. - 2 females (12.15; 12.40), MZUSP 8984, Vitória, Espírito Santo, 18.VIII.1987, Cia. Vale do Rio Doce coll. - CCDD 4122, Praia de Piúma (área central), Espírito Santo, Brazil, 2050'35.5"S/4043'53.8"W, 19.VI.2012, F. Carvalho, D.F. Peiró, R. Robles colls. - CCDD 4123, Praia de Iriri, Espírito Santo, Brazil, 2049'57.1"S/4041'36.7"W, 19.VI.2012, F. Carvalho, D.F. Peiró, R. Robles colls. - 4 females $(10.65 ; 12.80 ; 13.45 ; 14.20)$, MZUSP 25875, Praia das Conchas (lado esquerdo), Cabo Frio, Rio de Janeiro, Brazil, "obs.: prof. 2 m, coleta com tubo de sução", 31.10.2000, M. Tavares, J. Braga colls. - 2 females (1 1.50; 13.50), MZUSP 18847, Praia das Conchas, "Cabo Frio", Rio de Janeiro, Brazil, 30.I.2001, "obs. aprox. 5 m", M. Tavares, J.B. Mendonça. colls. - 3 males (8.60; 9.00; 9.60;), female (10.55), MZUSP 18851, Praia Rasa, Armação dos Buzios, Rio de Janeiro, 08.II.2001, M. Tavares, B. Mendonça Jr., Gary C.B. Poore colls. - 1 male (10.45) XDNA 1; 1 male (12.45) X-DNA 2, 1 male (10.00) X-DNA 3; 1 male (11.70), MZUSP 
25874, Praia Rasa, Buzios, Rio de Janeiro, Brazil, 15.06.2007, "obs. região entre marés", Joel Braga coll. - 1 male (13.85) "DNA voucher", 1 female (11.20) "DNA voucher", ULLZ 6055, Praia do Perequê-açu, Ubatuba, São Paulo, Brazil, (obs. collected with Pinnotheridae), 09.X.2000, R. Robles, F. Mantelatto coll. - 2 males (6.80; 7.85), 2 females (7.20; 8.00), 1 female (9.50) "extra tissues + X-DNA", unsexed (8.70), ULLZ 6056, Praia do Perequê-açu, Ubatuba, São Paulo, Brazil, (obs. collected with Pinnotheridae), 08.X.2000, R. Robles, F. Mantelatto coll. ("DNA extraction 28 May 2006") - 1 female (12.45), ULLZ 11729, São Paulo, Brazil, 10.XII.2000, F. Mantelatto, et al. coll. - CCDB 2661, Praia do Lázaro, Ubatuba, São Paulo, Brazil, 2330'24"S/4508'04"W, 23/11/2008, Peiró, D.F. coll. - CCDB 2872, Praia do Lázaro, Ubatuba, São Paulo, Brazil, 2330'24"S/4508'04"W, 23/11/2008, D.F. Peiró coll. - 1 male (8.15), 3 female $(8,50 ; 8.70 ; 10,50)$, MZUSP 14558, Praia da Fazenda (litoral norte SP), "Ubatuba, São Paulo, Brazil", 21.VIII.01, Biota FAPESP. Est 75 coll. - CCDB 712, Foz do Rio Juqueriquerê, Caraguatatuba, São Paulo, Brazil, 2342'29"S/45²5'34"W, 01.05.2009, D.F. Peiró, E.C. Mossolin colls. - 1 male (10.15), 1 female (8.85), MZUSP 14557, Caraguatatuba, 21.08.01, Biota FAPESP. Est 208 coll. - CCDB 4125, Praia da Guaiuba, Guarujá, São Paulo, Brazil, 2400'59,1"S/46¹7'38,7"W, 22.X.2011, N. Rossi, A. Costa, I. Leone, F. Carvalho colls. - 2 males (9.78; 14.60), 2 females (15.46; 15.90), MZUSP 7103, Praia José Menino, Santos, São Paulo, Brazil, 24.X.1984, S.A. Rodrigues coll. - 1 male (14.63), MZUSP 5673, Santos, São Paulo, Brazil, VIII.1978, S.A. Rodrigues coll. - 4 males (10.00; 11.95; 8.60; 11.00), MZUSP 12073, Praia José Menino, Santos, São Paulo, Brazil, 1991, S.A. Rodrigues coll. - 1 male (14.74), MZUSP 5672, Urubuquecaba, Santos, São Paulo, Brazil, 10.1976, S.A. Rodrigues-coll. - 1 male (11.25), MZUSP 5583, Ponta do Sol, Paranaguá, Paraná, Brazil, 24.Il.1978, S. Rodrigues coll. - 1 male (11.45), MZUSP 5582, Ponta 
do Sol, Paranaguá, Paraná, Brazil, 24.II.1978, S.A. Rodrigues coll. - 1 female (11.55), MZUSP 5839, Pontal do Sul, Paranaguá, Paraná, Brazil, 24.Il.1978, S. Rodrigues coll. - 1 female (12.15), MZUSP 5840, Pontal do Sul, Paranaguá, Paraná, Brazil, 24.II.1978, S. Rodrigues coll. - 1 female (7.35), MZUSP 5727, Praia Encantada (do Encantado), Ilha do Méu, Paraná, Brazil, 25.Il.1978, S. Rodrigues coll. - 1 female (9.2), 1 no determined (8.69), CCDB 2184, Praia Barra do Sai, Itapoá, Santa Catarina, Brazil, 2600'25.4"S/48³6'23.45"W, 20/02/2008, F.L. Mantelatto, E.C. Mossolin coll. - 1 male (12.15), MZUSP 5590, Praia da Enseada, São Francisco do Sul, Santa Catarina, Brazil, 23.XI.1978, S.A. Rodrigues-coll. - 1 ovigerous female (12.00), MZUSP 5740, Prainha, llha do Sul"?", Canal Galhetas"?", Brazil, 25.II.1978, S.A. Rodrigues-coll. - 1 female (13.10), MZUSP 5782, Armação, Santa Catarina, Brazil, 10.XII.1977, S.A. Rodrigues coll. - 1 male (14.45), MZUSP 5655, Armação, Santa Catarina, Brazil, 10.XII.1977, S.A. Rodrigues coll. - 1 female (14.60), MZUSP 5764, Armação (Penha - campo sul), Santa Catarina, Brazil, 22.II.1978, S.A. Rodrigues, coll. - 1 female (14.00), MZUSP 5784, Armação, Santa Catarina, Brazil, 10.XII.1977, S.A. Rodrigues coll. - 1 male (11.70), MZUSP 5597, Praia da Armação, São Miguel, Santa Catarina, Brazil, 16.XII.1977, S.A. Rodrigues coll. - 1 female (6.00), MZUSP 5843, Armação, Santa Catarina, Brazil, 10.XII.1977, S. Rodrigues col. - 1 female (6.30) MZUSP 5719, Praia São Miguel; Penha/Gravatá, Santa Catarina, Brazil, 22.II.1978, S.A. Rodrigues coll. - 1 male (7.50) MZUSP 5609, Praia São Miguel, Penha/Gravatá, Santa Catarina, Brazil, 22.II.1978, S.A. Rodrigues coll. - 4 males (6.15; 8.15; 8.88; 9.03), CCDB 2868, Praia Central, Balneário Camboriú, Santa Catarina, Brazil, 265'26"S/48³7'42"W, 14.III.2009, P. Pezzuto, E. Alves coll. - 1 female (13.15), MZUSP 5775, Itapema, Porto Belo (campo Norte), Santa Catarina, Brazil, 21.ll.1978, S.A. Rodrigues-coll. - 1 male (12.70), MZUSP 5634, Praia do Perequê, 
Porto Belo, Santa Catarina, Brazil, 15.XII.77, S.A. Rodrigues-coll. - 1 male (10.20), 2 females (10.50; 8.20), MZUSP 9569, Praia da Daniela, Florianopolis"?", Santa Catarina, Brazil, 1.II.1988, J.O. Branco coll.

Description (Figures 3, 4, 5, 6 and 7)

Description based on "Callianassa (Callichirus) major" sensu lato re-description from Brazilian territory by Rodrigues (1971).

Carapace. The anterior margin of the carapace is rigid. The rostrum is obtuse and flanked by two obtuse angles near the eyestalks base. From lateral view of the animal's body, the anterior margin of the carapace turns backwards to the linea thalassinica from where it becomes membranous and turns forwards to the rounded antero-lateral angles of the carapace (branchiostegite), which are situated approximately at the level of the base of the eyestalks. The linea thalassinica is distinct and runs parallel to the longitudinal axis of the body. The cervical groove is deep and defines the posterior part of the dorsal oval area of the carapace, as well as is distinctly delimited on the anterior part and laterals of the carapace. The sternum is inconspicuous between the first and third pairs of pereopods. It is expanded as a diamond-form between the fourth pair (close to the thigh). The sternum is also inconspicuous between the fifth pair. Eyestalks. They almost reach the end of the basal segment of the antennule peduncle. They are smooth, flattened, and blunt or sharp pointed. They are about 2.5 times as long as wide. They touch each other on the inner margins except at the tip where they diverge. The corneas are small and lie near the distal part of the external margins of the eyestalks. 
Antennule. The third segment is 1.5 to 2.5 times as longer as the first and second together. The antennule flagellum is slightly longer than the third segment of the peduncle.

Antenna. The peduncle reaches the beginning of distal half of the third segment of the antennule peduncle. The third segment is slightly longer as the second. The flagellum is almost four times as longer as the peduncle.

Mandible. Is provided with ten small sharp teeth. The mandibular palp is well developed and three-jointed.

Maxillula. Has a trapezoidal coxa provided with simple setae; the basis has the distal part expanded into a triangular lobe of which the apex has serrated setae. The palp is slender and one-jointed.

Maxilla. Has the coxa and basis distinctly separated and bilobed. The inner margin of the basis is provided with serrated setae. The palp is slender, reaching almost the distal extremity of the basis. The exopod is broad and acutely produced posteriorly.

First maxilliped. Has a single-lobed basis bearing, on the mesial border, serrated setae. The coxa is triangular. The palp is short and rudimentary. The exopod lacks the flagellum, but is somewhat jointed on the distal part. The epipod is well developed and expanded posteriorly into a thin, laminar projection.

Second maxilliped. Has the tip of the dactylus provided with serrated setae. The propodus is about three times-as long as the dactylus and carpus, whereas the merus is longer than the last three joints together. The exopod is almost as long as the merus and has minutely crenulated margins. The coxa has a leaf-like epipod and a rudimentary arthrobranch.

Third maxilliped. Has a slender dactylus with about $2 / 3$ of the length of the propodus. The propodus is a little broader than long and 2/3 of the length of 
the carpus. The merus is as long as the propodus and ischium. Coxa and basis bear no exopod or epipod.

The branchial formula and epipods and exopods presence are show in Table 2.

Table 2. Branchial formula and epipods and exopods presence in Callichirus macrotelsonis (Ortmann, 1893) comb. nov.

\begin{tabular}{l|ccc|ccccc}
\hline & \multicolumn{3}{|c|}{ Maxilipeds } & \multicolumn{5}{c}{ Pereopods } \\
& 1 & 2 & 3 & 1 & 2 & 3 & 4 & 5 \\
\hline Pleurobranchs & - & - & - & - & - & - & - & - \\
Arthrobranchs & - & $1 *$ & 2 & 2 & 2 & 2 & 2 & - \\
Podobranchs & - & - & - & - & - & - & - & - \\
Epipods & 1 & 1 & - & - & - & - & - & - \\
Exopods & 1 & 1 & - & - & - & - & - & - \\
*rudimentary & \multicolumn{1}{|c}{}
\end{tabular}

First pereopods. They are very unequal in shape, especially in developed males. It is rigid consistency. Major pereopod: on males, the ischium is flattened on the inner face and convex on the external face. Its upper margin is smooth with a spine at the proximal edge and the lower margin is granulated. On its inner surface has two grooves starting near the connection with the merus and run parallel the margins (lengthwise), until to join with the proximal portion of the ischium (near the connection to the base). The ischium is more than four times longer than wide. The merus is flattened on the inner face, convex on the external face. On ventral proximal margin (near the junction with the ischium), has a protruding granulated hook provided with (about 4-5) tufts of hairs on the margin. All the lower margin of the merus is granulated. The proximal half of the upper margin is also granulated. On its inner surface has two grooves starting near the connection with the carpus and run parallel the margins (lengthwise), until to join with the proximal portion of the merus (the same pattern presented on ischium). The carpus is convex on both sides. It is smooth and with few tufts 
of hairs on the upper margin. Slightly granulated in the proximal half of the lower margin. The carpus is about two times longer than wide. The propodus is convex on both sides, smooth, with tufts of hairs on both margins, denser at the lower margin of the fixed finger. The upper margin of the propodus is slightly longer than the merus and the ischium together. The upper and lower margins protrude slightly toward the carpus direction. The propodus in developed chelipeds has a v-shape protruding in between the dactylus and fixed finger. Some undeveloped males don't have a v-shape protruding in. The fixed finger tapers gradually toward the tip. It has a big gap in developed chelipeds (some males with undeveloped quelipeds don't have a gap) and bears tufts of hairs bordering the cutting edge on the external face. The fixed finger is straight at lower margin, sometimes curved at the tip. It has a small ledge on the proximal cutting edge (males with undeveloped quelipeds don't have, but bears tiny teeth on cutting edge). Not equipped with a strong and truncated tooth. The dactylus is curved and provided with a proximal "blunt" tooth and a smaller on 1/3 distal cutting edge (males with undeveloped quelipeds don't have, but has a row of ramp-shaped teeth). It has sparse tufts of hairs along the external margin. Variation on major queliped can be observed at Figures 6 and 7. Smaller pereopods: have the same shape in both sexes. The dactylus is almost entirely straight, slightly curved near the blunt or pointed tip, smaller or as long as the merus. It has a serrated prehensile edge. It has a dense row of tufts of hair parallel the prehensile edges. The propodus has hairs on upper and lower margins. The dactylus has tufts of hairs. The carpus is smooth, has a fold in the upper half, at the longitudinal axis on the external face. The carpus is approximately two times longer than wide. The ischium is as long as the merus, and more than three times longer than wide. 
Second pair of pereopods. They are chelated. The set propodus-dactylus (chelae) form together a sub-triangular structure. The dactylus, propodus, carpus and merus have long hairs at their margins. The dactylus is slightly larger than the fixed finger, no gaping, with small teeth on the cutting margin. It has a row of hairs parallel the cutting margin on the external face. The dactylus is about three times longer than the palm. The carpus is about two times longer than dactyl. The merus is as longer as the carpus and about three times longer than wide. The ischium is less wide than the merus, and approximately as wide as long.

Third pair of pereopods. Has the set propodus-dactylus forming together a distinct shovel-shaped structure. The propodus is transversally oriented in relation to the previous segment, it is wider than long. The set has many hairs on its margins, with longer hairs on the propodus anterior margins. The dactylus is almost as long as wide, and has two notches on the distal margins. The connection between the dactylus and propodus is concave (half-moon shaped).

Fourth pair of pereopods. Has imperfect chelae. The dactylus is smaller than the palm, with two notches on the upper margin. The fixed finger is shorter than the dactylus, reaching about the half of the dactylus, and has one or two inconspicuous teeth at the tip. The external face of the dactylus and of the propodus are densely covered by hairs. The carpus is about two and a half times longer than the dactylus. The merus is greater than the carpus and approximately two times the size of the ischium.

Fifth pair of pereopods. Has imperfect chelae, with spoon-shaped fixed fingers. The fixed finger has all serrated cutting margin. The propodus is extremely hairy, with a bundle of long hairs oriented differently from the upper margin on 
proximal internal face. Another hairy area fills up the inner distal margin from upper to lower margins of the propodus. The dactylus also has long hairs on its external face. The palm is approximately two times longer than the dactylus. The carpus is about one and a half times longer than the palm, and narrows toward the merus. The merus is more than four times longer than wide, and it is more than two times longer than the palm. The Ischium is approximately as long as wide.

Abdomen general overview. The first and second segments are membranous and soft. The second abdominal segment is longer than the first, and it is more than twice as longer than the third. The third, fourth and sixth segments have approximately the same length. The fifth segment is slightly larger than the adjacent.

First abdominal segment. Narrows towards the junction with the thorax. It is supported in each side by two rigid rods that meet with the sternitus near the second segment's margin. The sternitus extends from behind to forward to the middle of the segment. Males have thin and short pleopods, with only one branch.

Second abdominal segment. It is supported by two vitreous scales, more rigid than the rest of the segment. The segment is also supported ventrally by two rigid rods that meet the sternitus, forming a ventrally sub-triangular shape plate (like a three-pointed star). The plate starts together with the third segment and extends to the posterior half of the segment. The pleopods are two-branched. Third, fourth and fifth abdominal segments. Are stiffer than the previous ones, octagonal, sub-equal. They have the tergitus peculiarly carved, with symmetrical grooves. They have a mid-lateral band of hairs located transversally, reaching the margins of the pleura. Fifth abdominal segment. has 
a different carved pattern from the two previous ones. The pleopods of the third, fourth and fifth abdominal segments form lunate structures. The endopoditus left and right of each segment compose each one a half of the lunate structure, united at the middle by a sinsinuli at the distal portion. The exopoditus compose the edge of the lunate structure, intertwine reaching the adjacent half. At rest the whole structure lies above.

Sixth abdominal segment. IT is trapezoidal, and narrows toward the telson.

Telson. The length is about $3 / 4$ its width, the sixth abdominal segment is about one and a half times the size of the telson. There are an anterior median lobe that bears tuft of hairs on each side and two central tufts of hairs. Two posterior mid-lateral lobes separated by a deep notch that starts in approximately $2 / 3$ to the posterior margin; the lobes bears a tuft of hairs at distal margin. The lateral margins are anteriorly sinuous and posteriorly convex.

Uropods. Are about twice the size of the telson. The protopod has a sharp little thorn that lies on the dorsal surface of endopod. The exopod has a subtriangular shape, with rounded edges. The distal half is densely covered by hairs and the proximal portion has a distinct segment bearing a truncated tooth. The endopod is narrow sickle-shaped, approximately five times longer than wide. The proximal portion bears a small truncated tooth - sometimes pointed - that bears a small inconspicuous denticle.

Coloration. The extremities are whitish as well as the carapace, telson and uropods. Digestive glands are seen through the first and second abdominal segments, they are yellowish. The gonads are also seen through the integument, they are red in females and orange in males. 
Remarks: The C. major complex of species are close morphologically, sharing characters between them, as mentioned before. A lack of a complete description of the type species of the genus (the same of the complex), C. major s. s., prevents us from drawing a comparative profile with the species designated here. The description and redescriptions of C. major s. s. were made much earlier [original description by Say (1818); redescriptions by Hay \& Shore (1918) and by de Man (1928)], however they were not made taking into account the similarity within the species of the complex (descriptions with no more than 1 or 2 pages). Consequently, they are incomplete for comparing species in the complex. Even in descriptions of the genus and revisions (as $C$. major s. s. the type species) (Stimpson, 1866; Manning \& Felder, 1986), were not sufficient detailed permitting further comparisons. However, by our morphological analysis, C. macrotelsonis differs from C. major s. s. in the characters as described at diagnosis. This work provides a basis for future descriptions and redescriptions in the complex, and even within the genus. Taking into account that was mentioned above, is must recommended a review and redescription of C. major s. S. 


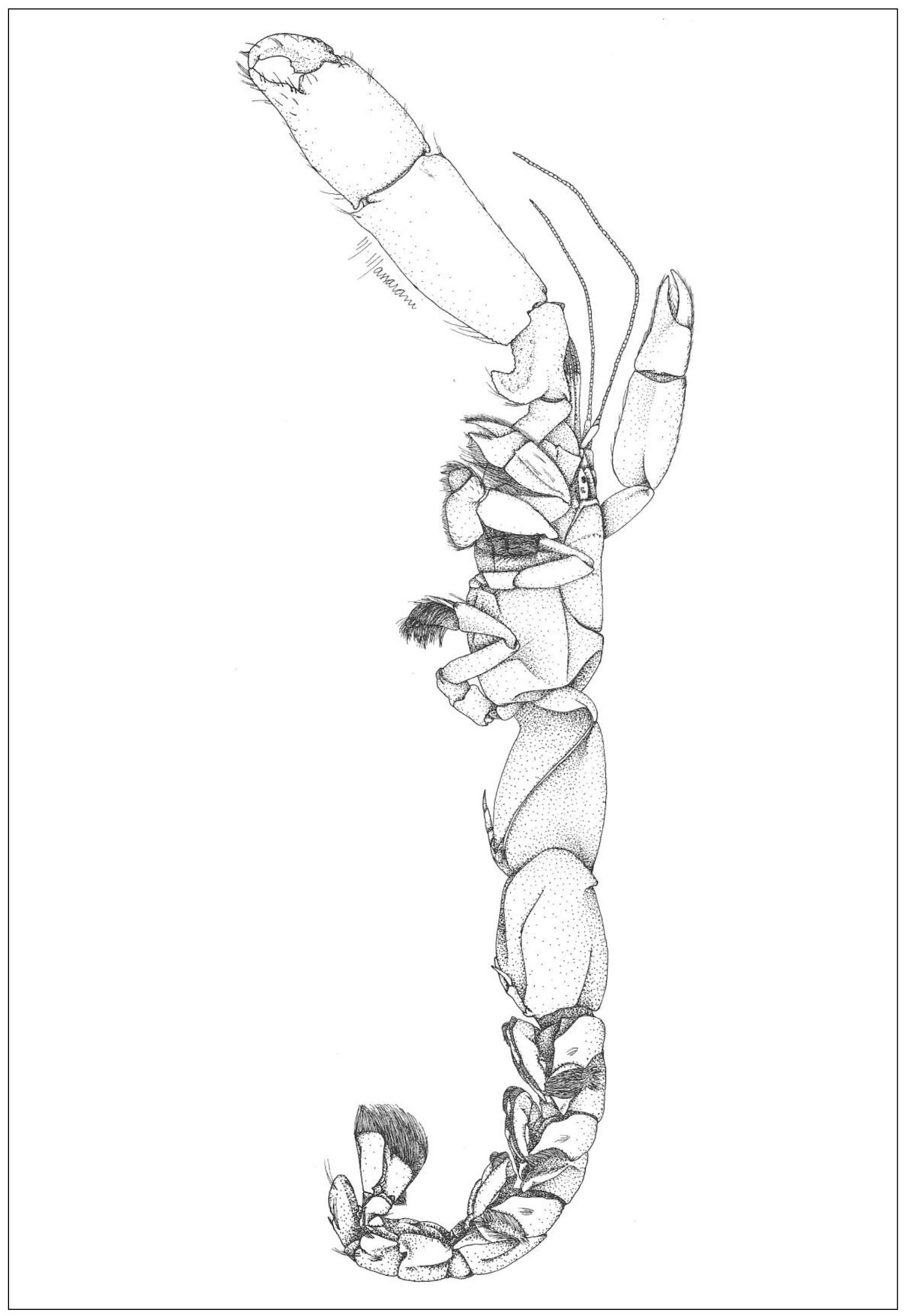

FIGURE 3. Callichirus macrotelsonis (Ortmann, 1893) comb. nov. from Brazilian coastlines. 


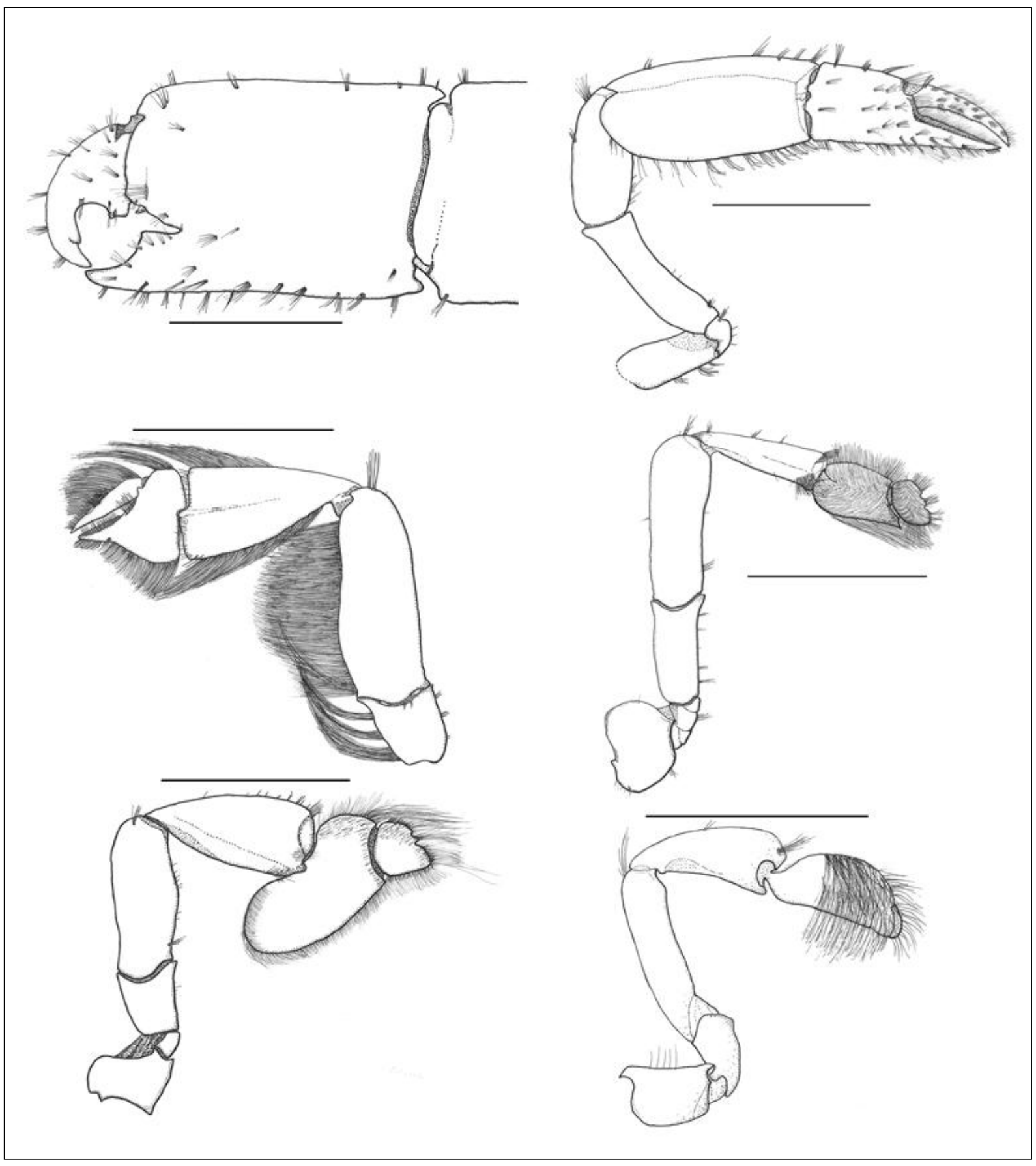

FIGURE 4. Callichirus macrotelsonis (Ortmann, 1893) comb. nov. first queliped left, firth pereopod right, second pereopod left, third pereopod right, fourth pereopod right, fifth pereopod right. Bars $=1 \mathrm{~cm}$. 


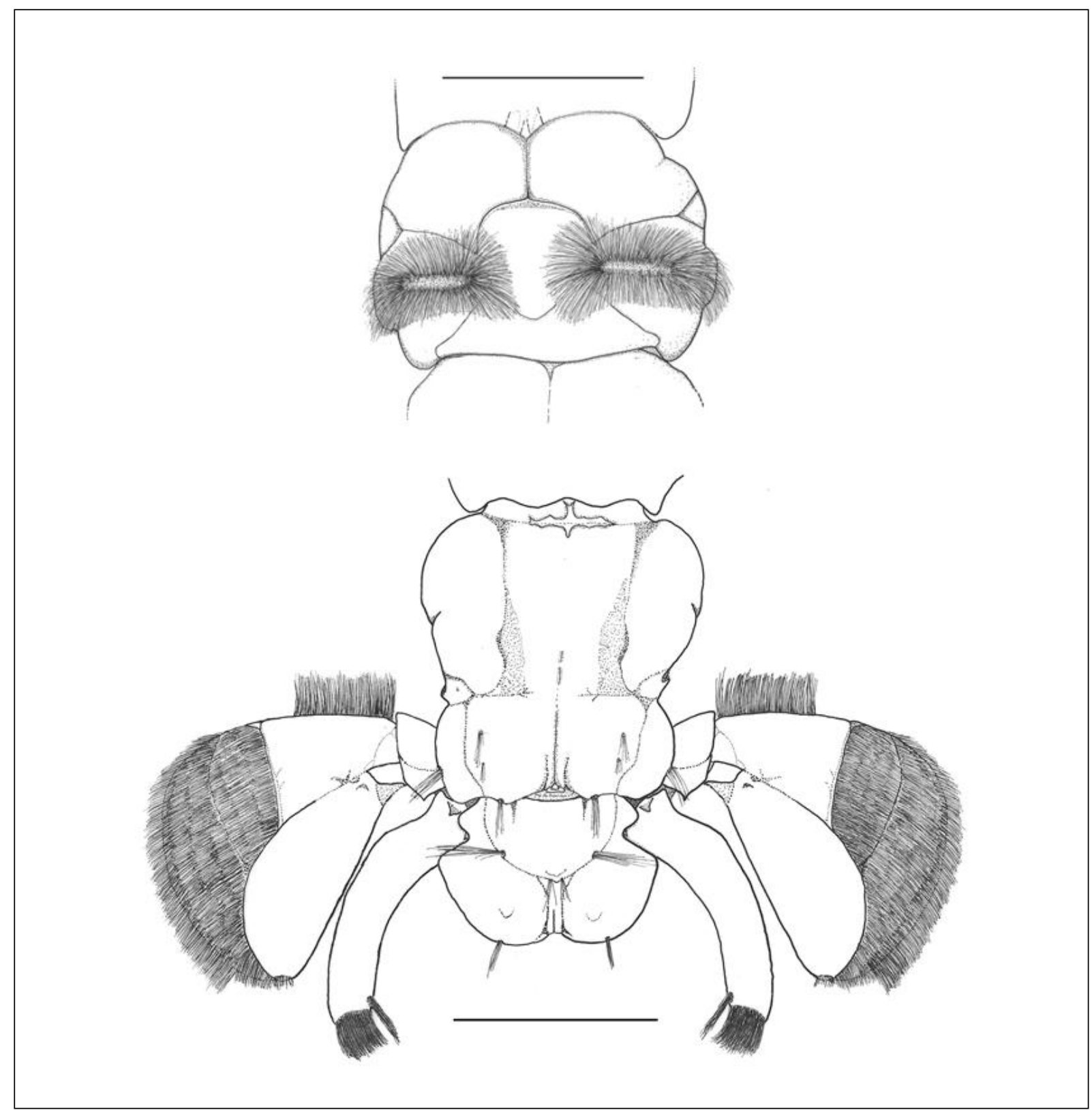

FIGURE 5. Callichirus macrotelsonis (Ortmann, 1893) comb. nov. third abdominal segment and sixth abdominal segment, telson and uropods. Bars $=1 \mathrm{~cm}$. 

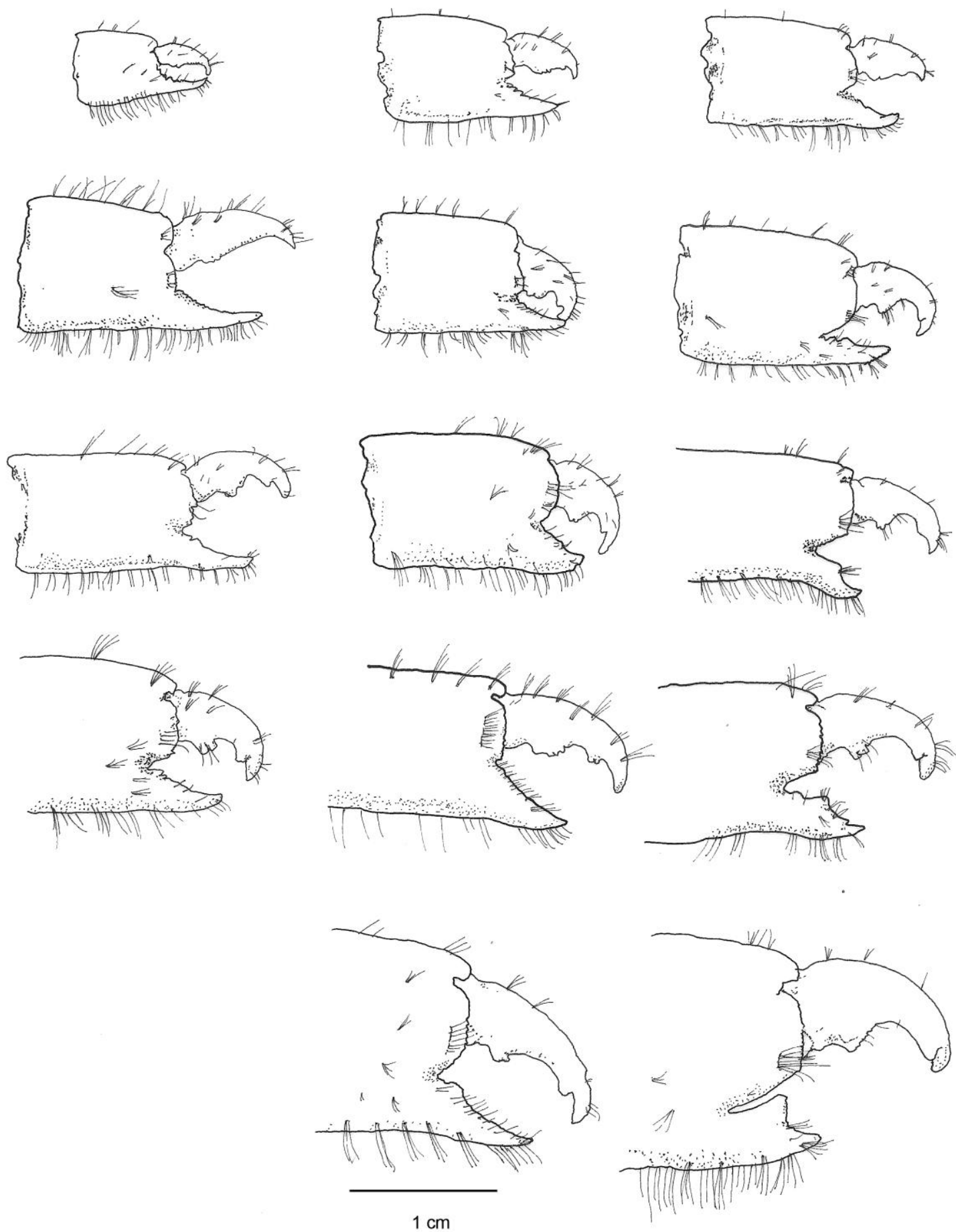

FIGURE 6. Callichirus macrotelsonis (Ortmann, 1893) comb. nov. right major quelipeds variety (redrawn from Rodrigues, 1983). 

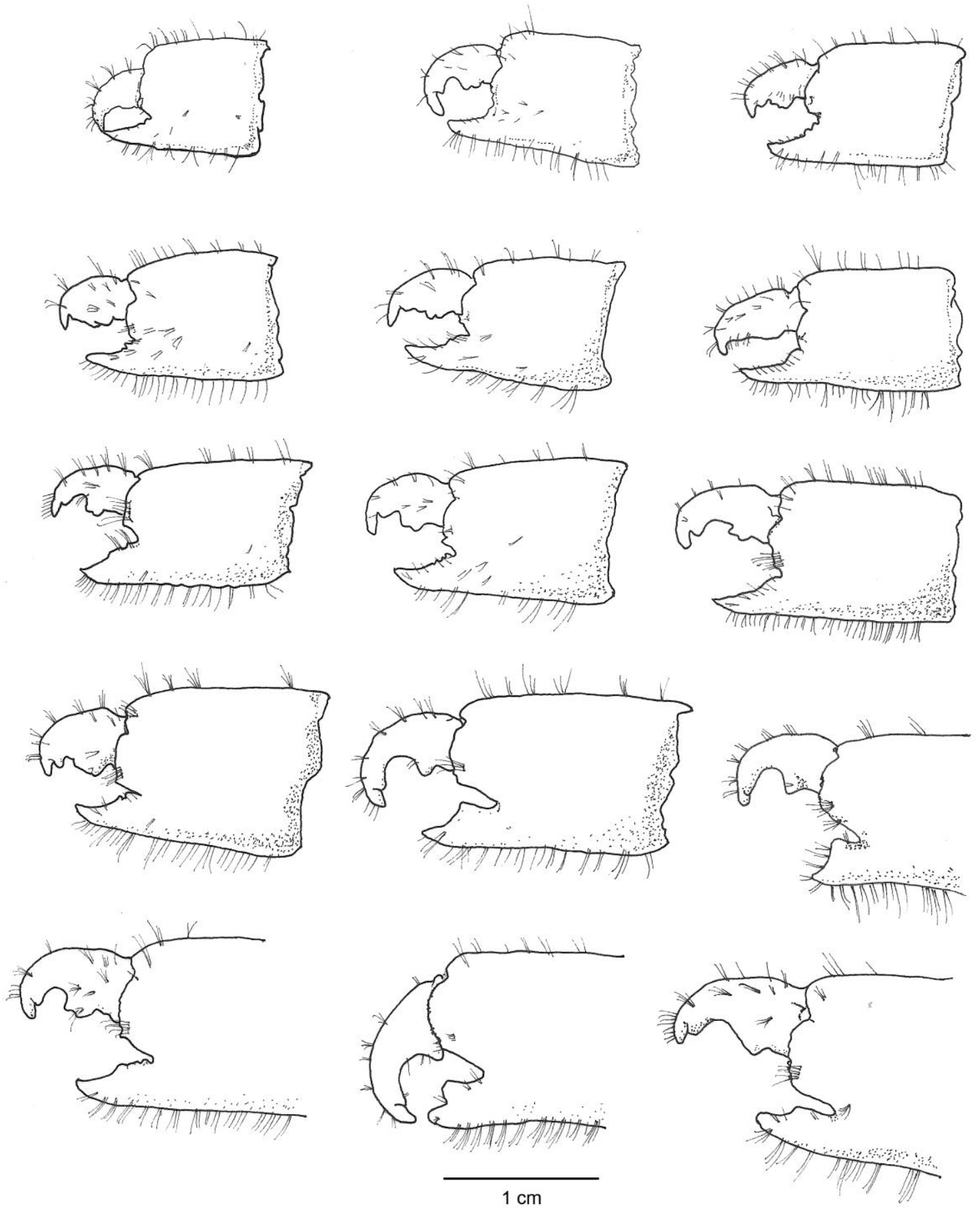

FIGURE 7. Callichirus macrotelsonis (Ortmann, 1893) comb. nov. left major quelipeds variety (redrawn from Rodrigues, 1983). 


\section{References}

Abrunhosa, F. A., Arruda, D. C. B., Simith, D. J. B. \& Palmeira, C. A. M. (2008) The importance of feeding in the larval development of the ghost shrimp Callichirus major (Decapoda: Callianassidae). Anais da Academia Brasileira de Ciências, 80, 445-453.

Alves, E. S. \& Rodrigues, S. A. (2003) Distributional patterns of Austinixa patagoniensis (Rathbun, 1918) (Decapoda: Pinnotheridae), a symbiotic crab of Callichirus major (Decapoda: Callianassidae) in Balneário Camboriú Beach, Santa Catarina, Brazil. Journal of Coastal Research, 35, 408-417.

Alves, E. S., Rodrigues, S. A. \& Pezzuto, P. R. (2005) Estudo do crescimento relativo de Austinixa patagoniensis (Rathbun) (Decapoda, Pinnotheridae) simbionte de Callichirus major (Say) (Decapoda, Callianassidae) no mesolitoral da praia de Balneário Camboriú, Santa Catarina, Brasil. Revista Brasileira de Zoologia, 22, 784-792.

Blanco-Rambla, J. P. (1997) Primer reporte de Callichirus major (Say) (Decapoda: Thalassinidea) para aguas venezolanas. Boletín del Instituto Oceanographico de Venezuela, Universidad de Oriente, 36, 7-13.

Borradaile, L. A. (1903) On the classification of the Thalassinidea. The Annals and Magazine of Natural History, series 7, 12, 534-551.

Borzone, C. A. \& Souza, J. R. B. (1996) A extração de corrupto Callichirus major (Decapoda: Callianassidae) para uso como iscas em praias do litoral do Paraná: características da pesca. Nerítica, 10, 67-79.

Botter-Carvalho, M. L., Santos, P. J. P. \& Carvalho, P. V. V. C. (2002) Spatial Distribution of Callichirus major (Say 1818) (Decapoda: Callianassidae) on a sandy beach, Piedade, Pernambuco, Brazil. Nauplius, 10, 97-109.

Botter-Carvalho, M. L., Santos, P. J. P. \& Carvalho, P. V. V. C. (2007) Population dynamics of Callichirus major (Say, 1818) (Crustacea, Thalassinidea) on a beach in northeastern Brazil. Estuarine Coastal and Shelf Science, 71, 508-516.

Castresana, J. (2000). Selection of conserved blocks from multiple alignments for their use in phylogenetic analysis. Molecular Biology and Evolution, 17, 540-552.

Coelho, P. A. \& Ramos, M. A. (1972) A constituição e a distribuição da fauna de decápodos do litoral leste da América do Sul entre as latitudes de $5^{\circ} \mathrm{Ne}$ $39^{\circ}$ S. Trabalhos Oceanograficos da Universidade Federal de Pernambuco, Recife, 13, 133-236.

Coelho, V. R. (1999) Adaptações morfológicas ao hábito alimentar em Thalassinidea (Crustacea: Decapoda). PhD Thesis, Instituto de Biociências, Universidade de São Paulo, São Paulo, 120pp. 
Coelho, V. R. \& Rodrigues, S. A. (2001) Setal diversity, trophic modes and functional morphology of feeding appendages of two callianassid shrimps, Callichirus major and Sergio mirim (Decapoda: Thalassinidea: Callianassidae). Journal of Natural History, 35, 1447-1483.

De Grave, S., Pentcheff, N. D., Ahyong, S. T., Chan, T.-Y., Crandall, K. A., Dworschak, P. C., Felder, D. L., Feldmann, R. M., Fransen, C. H. J. M., Goulding, L. Y. D., Lemaitre, R., Low, M. E. Y., Martin, J. W., Ng, P. K. L., Schweitzer, C. E., Tan, S. H., Tshudy, D. \& Wetzer, R. (2009) A classification of living and fossil genera of decapoda crustaceans. The Raffles Bulletin of Zoology, Supplement No. 21, 1-109.

Edgar, R.C. (2004a) MUSCLE: multiple sequence alignment with high accuracy and high throughput. Nucleic Acids Research, 32, 1792-97.

Edgar, R.C. (2004b) MUSCLE: a multiple sequence alignment method with reduced time and space complexity. BMC Bioinformatics, 5, 113.

Felder, D. L. \& Robles, R. (2009) Molecular phylogeny of the family Callianassidae based on preliminary analyses of two mitochondrial genes. In: Martin, J. W., Crandall, K. A. \& Felder, D. L. (Eds) Decapod Crustacean Phylogenetics. CRC Press, Taylor \& Francis Group, Boca Raton, London, New York, pp. 327-342.

Felsenstein, J. (1985) Confidence limits on phylogenies: an approach using the bootstrap. Evolution, 39, 783-791.

Frankenberg, D., Coles, S. L. \& Johannes, R. E. (1967) The potential trophic significance of Callianassa major fecal pellets. Limnology and Oceanography, 12, 113-120.

Hailstone, T. S. \& Stephenson, W. (1961) The biology of Callianassa (Trypaea) australiensis Dana 1852 (Crustacea, Thalassinidea). University of Queensland Papers, Department of Zoology, 1, 259-282.

Hall, B. G. (2011) Phylogenetic trees made easy: A how-to manual. 4rd edition. Sinaver Assaciates, Inc. Sunderland, Massachussets, USA, 233pp.

Hall, T. (2005) BioEdit v.7.05. Biological sequence alignmente editor for windows. Ibis Therapeutics a division of Isis pharmaceuticals. http://www.mbio.ncsu.edu/BioEdit/BioEdit.html

Heard R. W., King, R. A., Knott, D. M., Thoma, B. P. \& Thornton-DeVictor, S. (2007) A guide to the Thalassinidea (Crustacea: Malacostraca: Decapoda) of the South Atlantic Bight. NOAA Professional Paper NMFS 8, 30pp.

Manning, R. B. (1975) Two methods for collecting decapods in shallow water. Crustaceana, 29, 317-319. 
Manning, R. B. \& Felder D. L. (1986) The status of the callianassid genus Callichirus Stimpson, 1866 (Crustacea: Decapoda: Thalassinidea). Proceedings of the Biological Society of Washington, 99, 437-443.

Mantelatto, F. L., Robles, R., Biagi, R. \& Felder, D. L. (2006) Molecular analysis of the taxonomic and distributional statu s for the crab genera Loxopagurus Forest, 1964, and Isocheles Stimpson, 1858 (Decapoda, Anomura, Diogenidae). Zoosystema, 28, 495-506.

Mantelatto, F. L., Robles, R. \& Felder, D. L. (2007) Molecular phylogeny of the Western Atlantic species of the genus Portunus (Crustacea, Brachyura, Portunidae). Zoological Journal of the Linnean Society, 150, 21 1-220.

Mantelatto, F. L., Robles, R., Schubart, C. D. \& Felder, D. L. (2009) Molecular phylogeny of the genus Cronius Stimpson, 1860, with reassignment of C. tumidulus and several American species of Portunus to the genus Achelous De Haan, 1833 (Brachyura: Portunidae). Decapod Crustacean Phylogenetics, 18, 551-565.

Melo, G. A. S. (1999) Manual de identificação dos Crustacea Decapoda do litoral Brasileiro: Anomura, Thalassinidea, Palinuridea, Astacidea. Editora Plêiade/FAPESP, São Paulo, $551 \mathrm{pp}$.

Morrison, C. L., Harvey, A. W., Lavery, S., Tieu, K., Huang, Y. \& Cunningham, C. W. (2002) Mitochondrial gene rearrangements confirm the parallel evolution of the crab-like form. Proceedings of the Royal Society of London. Series B: Biological Sciences, 269, 345-350.

Nucci, P. R. \& Melo, G. A. S. (2011) Decapoda. In: Amaral, A. C. Z. \& Nallin, S. A. H. (Eds). Biodiversidade e ecossistemas bentônicos marinhos do Litoral Norte de São Paulo, Sudeste do Brasil. Unicamp/IB, Campinas/SP, pp. 147-154.

Ortmann, A. E. (1893) Decapoden und Schizopoden. Ergebnisse der PlanktonExpedition der Humbolt-Stiftung im Atlantischen Ozean, November 1889, $2,1-120$.

Peiró, D. F. \& Mantelatto, F. L. (2011) Population dynamics of the pea crab Austinixa aidae (Brachyura, Pinnotheridae): a symbiotic of the ghost shrimp Callichirus major (Thalassinidea, Callianassidae) from the southwestern Atlantic. Iheringia, Série Zoologia, 101, 5-14.

Peiró, D. F., Pezzuto, P. R. \& Mantelatto, F. L. (2011) Relative growth and sexual dimorphism of Austinixa aidae (Brachyura: Pinnotheridae): a symbiont of the ghost shrimp Callichirus major from the southwestern Atlantic. Latin American Journal of Aquatic Research, 39, 261-270.

Peiró, D. F., Baeza, J. A. \& Mantelatto, F. L. (2012) Host-use pattern and sexual dimorphism reveals the mating system of the symbiotic pea crab Austinixa aidae (Crustacea: Brachyura: Pinnotheridae). Journal of the 
Marine Biological Association of the United Kingdom, DOI $10.1017 /$ S0025315412000720

Peiró, D. F., Buckup, L. \& Mantelatto, F. L. (in press) Avaliação do estado da conservação do "corrupto" de praia Callichirus major (Say, 1818) sensu lato (Crustacea, Decapoda, Callianassidae) no Brasil. Biodiversidade Brasileira.

Peiró, D. F., Wehrtmann, I. S. \& Mantelatto, F. L. (submitted) Reproductive strategy of the ghost shrimp Callichirus macrotelsonis (Ortmann, 1893) (Callianassidae) in the southeastern Atlantic: sexual maturity of females, fecundity, egg features and reproductive output. Invertebrate Reproduction \& Development.

Peiró, D. F. \& Mantelatto, F. L. (in preparation) Population dynamics of the ghost shrimp Callichirus macrotelsonis (Ortmann, 1893) from a sandy beach in southeastern Atlantic, Brazil.

Porter, M.L., Perez-Losada, M. \& Crandall, K.A. (2005) Model-based multi-locus estimation of decapod phylogeny and divergence times. Molecular Phylogenetics and Evolution, 37, 355-369.

Rodrigues, S. A. (1966) Estudos sobre Callianassa: Sistemática, Biologia e Anatomia. PhD Thesis, Faculdade de Filosofia Ciências e Letras, Universidade de São Paulo, São Paulo, Brazil, 169pp.

Rodrigues, S. A. (1971) Mud shrimps of the genus Callianassa Leach from the Brazilian coast (Crustacea, Decapoda). Arquivos de Zoologia, 20, 191223.

Rodrigues, S. A. (1976) Sobre a reprodução, embriologia e desenvolvimento larval de Callichirus major Say, 1818 (Crustacea, Decapoda Thalassinidea). Boletim de Zoologia Universidade de São Paulo, 1, 85-104.

Rodrigues, S. A. (1983) Aspectos da biologia de Thalassinidea do Atlântico tropical americano. Livre Docência Thesis, Instituto de Biociências da Universidade de São Paulo, São Paulo, Brazil, 194pp.

Rodrigues, S. A. (1984) Desenvolvimento pós-embrionário de Callichirus mirim (Rodrigues, 1971) obtideo em condiçoes artificiais (Crustacea, Decapoda, Thalassinidea). Boletim de Zoologia Universidade de São Paulo, 8, 239-256.

Rodrigues, S. A. (1985) Sobre o crescimento relativo de Callichirus major (Say, 1818) (Crustacea, Decapoda, Thalassinidea). Boletim de Zoologia Universidade de São Paulo, 9, 195-211.

Rodrigues, S. A. \& Shimizu, R. M. (1997) Autoecologia de Callichirus major (Say, 1818). Oecologia Brasiliensis, 3, 155-170. 
Rodrigues, S. A. \& Hödl, W. (1990) Burrowing behaviour of Callichirus major and C. mirim. Begleitveröffentlichung zum wissenschaftlichen Film C 2199 des ÖWF. Wissenschaftlicher Film, 41, 48-58.

Rodrigues, S. A. \& Shimizu, R. M. (1998) Thalassinidea. In: Yung, P. S. (Ed.) Catalogue of Crustacea of Brazil. Museu Nacional, Rio de Janeiro, pp. 379-385.

Russo, C. A. M., Miyaki, C. Y. \& Pereira, S. L. (2001) Reconstrução Filogenética: Métodos Geométricos. In: Matioli, S. R. (Ed) Biologia molecular e Evolução. Holos Editora, Ribeirão Preto, pp. 108-116.

Saint Laurent, M. de (1973) Sur la systématique et la phylogénie des Thalassinidea: définition des familles des Callianassidae et des Upogebiidae et diagnose de cina genres nouveaux (Crustacea Decapoda). Comptes rendus hebdomadaires des séances de l'Académie, des sciences, série D, 277, 513-516.

Say, T. (1817-1818) An account of the Crustacea of the United States. Journal of the Academy of Natural Sciences, Philadelphia, 1, 57-63, 65-80 (plate 4), 97-101, 155-160, 161-169, 235-253, 313-319, 374-380, 381-401, 423-441.

Schubart, C. D., Neigel, J. E. \& Felder, D. L. (2000a) Use of the mitochondrial 165 rRNA gene for phylogenetic and population studies of Crustacea. Crustacean Issues, 12, 817-830.

Schubart, C. D., Cuesta, J. A., Diesel, R. \& Felder, D. L. (2000b) Molecular phylogeny, taxonomy, and evolution of nonmarine lineages within the American grapsoid crabs (Crustacea: Brachyura). Molecular Phylogenetics and Evolution, 15, 179-190.

Schubart, C. D., Cuesta, J. A. \& Felder, D. L. (2002) Glyptograpsidae, a new brachyuran family from Central America: larval and adult morphology, and a molecular phylogeny of the Grapsoidea. Journal of Crustacean Biology, 22, 28-44.

Schneider, H. (2007) Métodos de Análise Filogenética: Um guia prático. $3^{a}$ Edição. Editora Holos, Ribeirão Preto, 200 pp.

Shimizu, R. M. (1997) Ecologia populacional de Scolelepis squamata (Muller, 1806) (Polychaeta: Spionidae) e Callichirus major (Say, 1818) (Crustacea: Decapoda: Thalassinidae) da Praia de Barequeçaba (São Sebastião, SP). PhD Thesis, Instituto de Biociências da Universidade de São Paulo, São Paulo, Brazil. 49 pp.

Shimizu, R. M. \& Rosso, S. (2000) Influence on an oil spill on the abundance of Callichirus major (Say, 1818) on a sandy beach in southeastern Brazil (Crustacea: Decapoda: Thalassinidea). Nauplius, 8, 63-72

Simão, D. S.; Ramos, M.F. \& Soares-Gomes, A. (2006) Population Structure of Callichirus major (Say 1818) (Crustacea: Thalassinidea) in a Sandy Beach 
of Rio de Janeiro State, Southeast Brazil Coast. In: Proceedings of International Coastal Symposium 2004. Journal of Coastal Research, Special Issue, 39, $1165-1168$.

Souza, J. R. B. \& Borzone, C. A. (1996) Distribuição de callianassideos (Crustacea: Decapoda: Thalassinidea) em praias do litoral Paranense, com especial referencia a Callichirus major (Say, 1818) [Distribution of callianassids (Crustacea: Decapoda: Thalassinidea) on Parana State beaches, with special reference to Callichirus major (Say, 1818)]. Arquivos de Biologia e Tecnologia, 39, 553-565.

Souza, J. R. B. \& Borzone, C. A. (2003) A extração de corrupto, Callichirus major (Say) (Crustacea, Thalassinidea), para uso como isca em praias do litoral do Paraná: as populações exploradas. Revista Brasileira de Zoologia, 20, 625-630.

Souza, J. R. B., Borzone, C. A. \& Brey, T. (1998) Population dynamics and secondary production of Callichirus major (Crustacea, Thalassinidea) on a southern Brazilian sandy beach. Archive of Fishery and Marine Research, 46, 151-164.

Stamatakis, A. (2006) RAxML-VI-HPC: Maximum likelihood-based phylogenetic analyses with thousands of taxa and mixed models. Bioinformatics, 22, 2688-2690.

Staton, J. L. \& Felder, D. L. (1995) Genetic variation in populations of the ghost shrimp genus Callichirus (Crustacea: Decapoda: Thalassinoidea) in the western Atlantic and Gulf of Mexico. Bulletin of Marine Science, 56, 523536.

Stimpson, W. (1866) Descriptions of new genera and species of Macrurous Crustacea from the coasts of North America. Proceedings of the Chicago Academy of Sciences, 1, 46-48.

Stimpson, W. (1871) Notes on North American Crustacea in the Museum of the Smithsonian Institution. No. III. Annals of the Lyceum of Natural History of New York, 10, 92-136.

Strasser, K. M. \& Felder, D. L. (1999a) Larval development of two populations of the ghost shrimp Callichirus major (Decapoda: Thalassinidea) under laboratory conditions. Journal of Crustacean Biology, 19, 844-878.

Strasser, K. M. \& Felder, D. L. (1999b) Settlement in an Atlantic coast population of the ghost shrimp Callichirus major (Crustacea: Decapoda: Thalassinidea). Marine Ecology Progress Series, 183, 217-225.

Xia, X. \& Xie, Z. (2001) DAMBE: Software package for data analysis in molecular biology and evolution. Journal of Heredity, 92, 371-373. 


\section{Capítulo II}

Reproductive strategy of the ghost shrimp Callichirus macrotelsonis (Ortmann, 1893) (Crustacea: Axidea:

Callianassidae) in the southeastern Atlantic: sexual maturity of females, fecundity, egg features and reproductive output Artigo submetido à revista Invertebrate Reproduction \& Development, 2012 


\section{Reproductive strategy of the ghost shrimp Callichirus macrotelsonis (Ortmann,}

1893) (Crustacea: Axidea: Callianassidae) in the southeastern Atlantic: sexual maturity of females, fecundity, egg features and reproductive output

Douglas F. Peiró', Ingo S. Wehrtmann ${ }^{2,3}$ and Fernando L. Mantelatto ${ }^{*}$

1 Laboratory of Bioecology and Crustacean Systematics (LBSC), Department of Biology, Faculty of Philosophy, Science and Letters of Ribeirão Preto (FFCLRP), University of São Paulo (USP), Postgraduate Program in Comparative Biology. Av. Bandeirantes 3900, 14040-901, Ribeirão Preto (SP), Brazil.

2 Unidad de Investigación Pesquera y Acuicultura (UNIP) of the Centro de Investigación en Ciencias del Mar y Limnología (CIMAR), Universidad de Costa Rica, 11501-2060 San José, Costa Rica.

${ }^{3}$ Museo de Zoología, Escuela de Biología, Universidad de Costa Rica, 11501 2060 San José, Costa Rica. e-mail: ingowehrtmann@gmx.de

\section{*Corresponding author: flmantel@usp.br}

Keywords: Fitness, reproduction, reproductive investment, RO, sandy beach. 


\section{Abstract}

Reproduction and reproductive investment of females is an intriguing feature in axiidean shrimps. They have a cryptic behavior and a high ecological importance on turnover sediment, organic material and nutrients. Herein we describe different aspects of the reproductive biology (size at sexual maturity of females, fecundity, eggs characteristics and reproductive output, RO) of a recently redesigned species of callianassid, the ghost shrimp Callichirus macrotelsonis from the southeastern coast of Brazil. Females reached sexual maturity at sizes $\geq 11.85 \mathrm{~mm} \mathrm{CL}$. Fecundity increased significantly with female size and varied between 1455 and 9931 eggs (average 4564 eggs). Egg volume almost doubled during embryogenesis, and average egg water content increased during the incubation period from $75.0 \%$ to $93.3 \%$. The egg mass comprised on average $13.2 \%$ of the dry body weight of females This relatively high reproductive output ( $R O$ ) value is probably compensatory to the relatively low number of ovigerous females in axiidean populations. The few published data on RO values seem to suggest that female investment in reproduction of axiidean shrimps is somewhat higher than in other decapods. The high investment in egg production is probably an effort to maximize the viability of the progeny. Studies with additional species will clarify whether there exist a tendency of axiidean shrimps to have RO values at the upper end of the range reported for decapods. 


\section{Introduction}

Shrimps of the Infraorders Axiidea and Gebiidea inhabit mainly intertidal and subtidal zones and constitute a decapod group well known for being excavators of all types of marine sediments (Dworschak 2000). Their complex galleries represent a mosaic of habitats, often utilized by a variety of associated organisms (Itani and Kato 2002; Berkenbusch and Rowden 2003; Itani 2004). The bioturbating activities of these shrimps increase significantly the turnover rate of sediments and organic material, and enhance nutrient cycling (Waslenchuk et al. 1983; Branch and Pringle 1987; Ziebis et al. 1996; Webb and Eyre 2004). These activities facilitate the redistribution of metals and contaminants (Suchanek et al. 1986; Abu-Hilal et al. 1988), and enrich the oxygen content within the sediments (Hughes 2000).

Despite their ecological importance, our knowledge about the life history and especially the reproductive biology of axiidean species is far from complete (Tamaki et al. 1996; Thessalou-Legaki and Kiortsis 1997; Hernáez et al. 2008). This deficiency is accompanied by a lack of information on environmental adaptations of these shrimp populations. Environmental conditions, i.e. temperature, have been demonstrated to have profound impacts on the ecology of shallow-water (intertidal) marine decapod populations (Giese 1959; Jones and Simons 1983; Pinheiro and Fransozo 1995; Terossi et al. 2010). Thus, it can be expected that axiids may have developed specific adaptations to survive and reproduce in this highly variable and rapidly changing coastal environment (Griffis and Suchanek 1991; Berkenbusch and Rowden 2000).

Data on reproductive features and the associated environmental conditions are indispensable for our understanding of the evolution of 
reproductive strategies in decapods (Berkenbusch and Rowden 2000; Lardies and Castilla 2001). To facilitate a general comparison of energy investment for reproduction among decapods, two concepts have been used in the literature: 1. Reproductive effort (RE), which refers to the fraction of the total energy available utilized for reproduction (Tinkle and Hadley 1975; Hines 1982; Clarke 1987). This concept includes the energy inverted e.g. in foraging activities, territorial behavior as well as energy allocated to carry and protect the offspring. In the practical way, it is difficult to obtain all the information required to calculate the RE; 2 . In contrast, the reproductive output (RO) represents the energy inverted in egg production in relation to the female weight (Pianka 1972; Hines 1992; Thessalou-Legaki and Kiortsis 1997). This approximation of energy allocation in reproduction has been widely used in studies concerning reproductive features in different groups of marine decapods (Clarke et al. 1991; Lardies and Wehrtmann 1997; Colpo and Negreiros-Fransozo 2003; Miranda et al. 2006; Cobo and Okamori 2008; Torati and Mantelatto 2008; Lara and Wehrtmann 2009; Pavanelli et al. 2010).

Studies on fecundity are important to determine the reproductive potential of species and/or the populations. The results of such studies allow inferring about the adaptations and reproductive strategies in relation to the environmental condition (Sastry 1983; Mantelatto and Fransozo 1997). The fecundity may be influenced by factors as habitat, intra- and interspecific adaptations, and the life style of the species (Sastry 1983). Several studies have demonstrated an intraspecific latitudinal cline of fecundity, RO and egg size in marine decapods with a wide geographical distribution (Jones and Simons 1983; Clarke et al. 1991; Lardies and Wehrtmann 1997; Lardies and Castilla 2001; Terossi et al. 2010). 
Another factor of ecological importance concerning the reproduction is the size of eggs, in many cases the only way to estimate quantitatively the contribution of one generation of individuals to their offspring (Timofeev and Sklyar 2001). The egg volume is considered as an indicator of the energy allocation for the embryonic development, and it is important for understanding the mechanisms utilized by the population to adapt to their environment and its resources in order to survive and reproduce (Torati and Mantelatto 2008).

The taxonomic status of the species studied by us has been somewhat unclear, in part due to the wide range of geographical distribution and due to morphological characteristics shared among "populations" of Callichirus major (SAY, 1818) sensu lato (a complex of species) (Staton and Felder 1995; Strasser and Felder 1999a; 1999b; Rodrigues and Shimizu, 1997; Peiró et al. submitted). Based on molecular and morphological approaches two of us (Peiró et al. submitted) are designing Callichirus macrotelsonis comb. nov. to the "Brazilian species" of the C. major (complex); originally treated as Callichirus major.

Callichirus macrotelsonis (ORTMANN, 1893) inhabits dissipative sandy beaches in the western Atlantic coast, Brazil, from State of Para to State of Santa Catarina (Melo 1999; Abrunhosa et al. 2008, both referred as C. major; Peiró et al. submitted). This species presents a cryptic behavior, lives individually in deep burrows located in intertidal or shallow sub-tidal areas (Rodrigues and Shimizu 1997, referred as C. major).

The following studies mention reproductive features of C. macrotelsonis (as C. major), such as general biology and anatomy (Rodrigues, 1966; Rodrigues, 1983), embryology and larval development (Rodrigues, 1976), and reproductive period, size of ovigerous females and fecundity (Rodrigues and 
Shimizu, 1997; Shimizu, 1997; Souza et al. 1998; Simão et al. 2006; Botter-Carvalho et al. 2007; Ramos et al. 2007; Sendim et al. 2007). Therefore, the purpose of the present study is to provide information concerning important aspects of the reproductive biology (size at sexual maturity of females, fecundity, egg characteristics, reproductive output) of C. macrotelsonis from the southeastern coast of Brazil. The results obtained are compared with those from other ghost shrimps of the genus and Callianassidae family, which may contribute to a better understanding of the evolution of reproductive strategies in ghost shrimps.

\section{Material and Methods}

\section{Collection of material}

Ovigerous females of C. macrotelsonis were collected bimonthly (September 2008 to July 2009) in the intertidal zone of the Perequê-açu Beach, Ubatuba, State of São Paulo, Brazil $\left(23^{\circ} 24^{\prime} S, 45^{\circ} 03^{\prime} \mathrm{W}\right)$ (Fig. 1). The study area is a semi-protected and dissipative beach composed by fine sand (Peiró et al. 2012). Sampling was conducted during daytime low tide; specimens were collected manually from their galleries with two sucking pumps $11 \mathrm{~m}$ length; 5 $\mathrm{cm}$ tube diameter). The applied methods coincide with those described by Rodrigues (1966) and Manning (1975).

The collected ghost shrimps were stored individually in labeled plastic bags, which were frozen for subsequent analyses. In the laboratory, specimens were transferred into glass vials and preserved in ethyl alcohol of $80 \%$. From each ovigerous female we measured the carapace oval area length $(\mathrm{CL})$ and abdomen width (AW) with the aid of a $\operatorname{Zass}^{\circledR}$ caliper (precision: $0.05 \mathrm{~mm}$ ); subsequently the specimens were weighted with an analytical balance 
Scientech ${ }^{\circledR}$ AS 210 (precision: $0.0001 \mathrm{~g}$ ). In each sampling period, the superficial water temperature was measured before the collection.

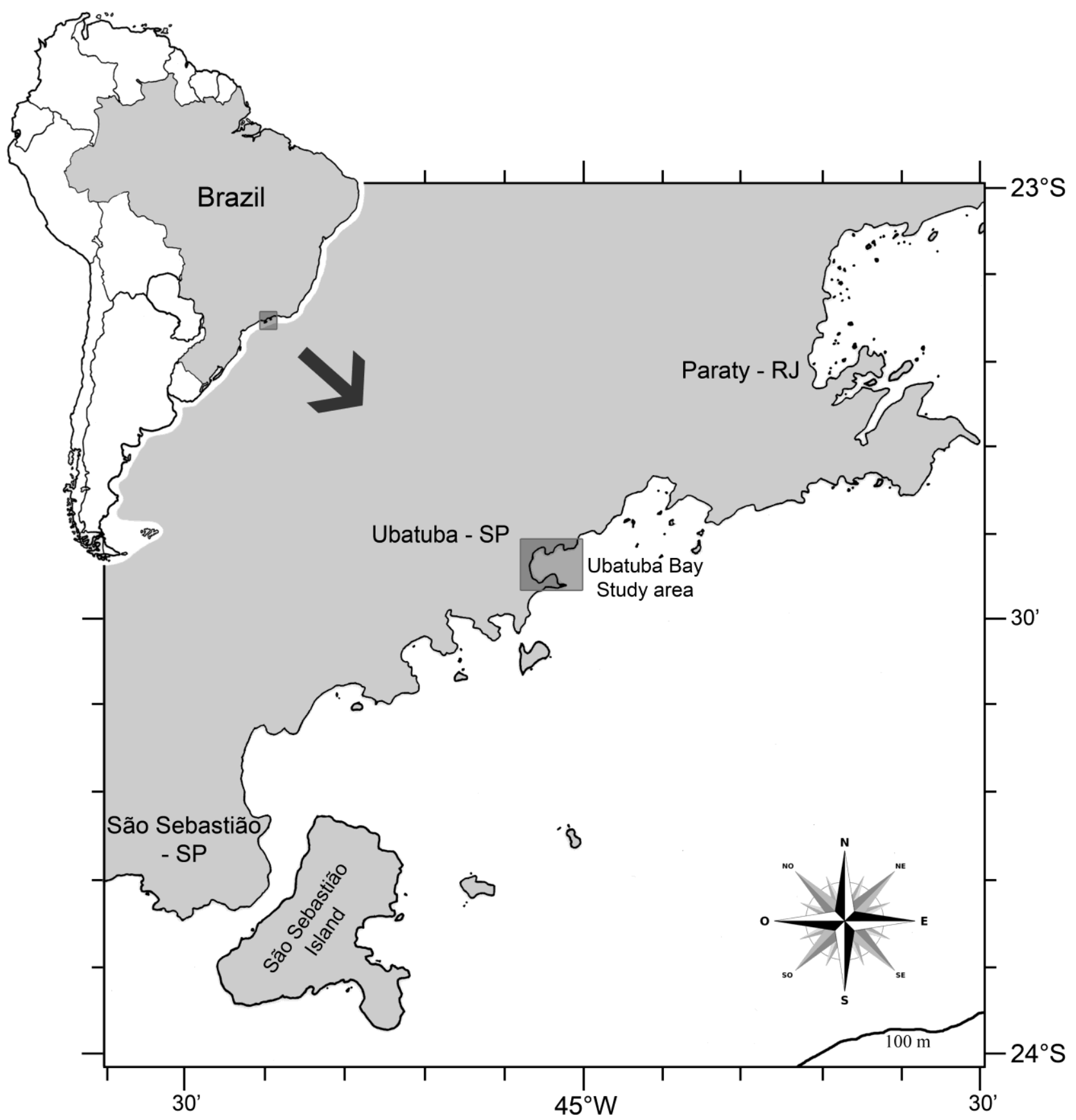

Figure 1. Location of the Ubatuba Bay study area, northern State of São Paulo (SP), southeastern Brazil. 
Females were classified in two groups concerning its ratio $\mathrm{AW} / \mathrm{CL}$ versus CL (see results for details). Immature females: ratios $<0.97$ and sizes $<11.85 \mathrm{~mm}$ CL; mature females: ratios $\geq 0.97$ and sizes $\geq 11.85 \mathrm{~mm} \mathrm{CL}$ (McDermott 2006; Peiró and Mantelatto 2011). Ovigerous females refer to those with eggs adhered on pleopods.

\section{Egg production}

The total egg mass was separated from each female. The embryonic stage of the eggs was classified according to the methodology proposed by Boolootian et al. (1959) and modified by Mantelatto and Garcia (1999), representing three developmental stages: (Stage I) early stage: yolk occupying at least $3 / 4$ of the egg; (Stage II) intermediate stage: eyes become visible, with yolk occupying less than $3 / 4$ of the egg; (Stage III) final stage: embryo completely visible, yolk absent, close to hatching.

To analyze the egg production in C. macrotelsonis, we utilized all 25 ovigerous females collected during the study period as well additional material obtained from previous collections carried out at the same location in November $2005(n=2)$, January $2006(n=1)$ and July $2008(n=2)$. Egg production was estimated based upon females carrying freshly-extruded eggs (Stage I). The entire egg mass was carefully separated from the pleopods, placed in a Petri dish, and eggs were counted under a dissecting microscope. We selected arbitrarily 15 eggs to calculate the egg volume $\left(\mathrm{mm}^{3}\right)$ according to the formula: 1/6 $\mathrm{I}^{3}$ (Jones and Simons 1983) where "l" represents the mean of maximum and minimum egg diameter; eggs were measured under a dissecting microscope Zeiss $^{\circledR}$ Stemi SV6 with a precision of $0.1 \mathrm{~mm}$. This methodology was applied to eggs of the three developmental stages to assess 
the possible presence of changes in the number, volume and shape of the eggs during the incubation period.

After measuring the eggs, they were washed with distilled water, which was removed subsequently with absorbing paper towels. The eggs were dried at $50^{\circ} \mathrm{C}$ until they attained a constant dry weight (approximately after 24 hours). Egg weight was determined with the aid of an analytical balance (Scientech ${ }^{\circledR}$ AS 210) with a precision of 0.0001 g. Afterwards, eggs were combusted for approximately five hours at $500^{\circ} \mathrm{C}$ to obtain their ash weight. Organic content was estimated by subtracting ash weight from dry weight; the inorganic content was considered the proper ash mass. The same procedures were applied for the ovigerous females (without eggs), except that dry and ash weight was obtained after 48 and 12 hours, respectively (Lardies and Wehrtmann 1997).

The reproductive output (RO) was calculated only for females with eggs in Stage I. We followed the methodology described by Clarke et al. (1991) to calculate RO: dry weight of the total egg batch / dry weight of the female without eggs.

\section{Data analysis}

The normality of the size-frequency distribution of ovigerous females was tested by the Shapiro-Wilk test (Shapiro and Wilk 1965). The number of classes was determined by the Sturges (1926) formula: $k=1+\log 2 n$; " $k$ " is the number of classes and " $n$ " is the size of sample.

We utilized a correlation coefficient to describe the relations between $\mathrm{CL}$ of ovigerous females and the number of eggs (Pearson product moment correlation - Zar 1996). The Kruskal-Wallis analysis of variance was applied to 
compare the mean female size among the three stages of embryo development and the mean number of eggs recorded for each embryonic developmental stage.

An Analysis of Covariance (ANCOVA) was used to analyze changes of the mean egg volume during the incubation period (of all three developmental stages), and a posteriori Tukey test was applied to detect possible significant differences between the egg stages.

All statistical analyses were conducted with the program PAST - Version 1.49 (Hammer et al. 2001), following the procedures proposed by Zar (1996), and using a level of significance of $P<0.05$.

\section{Results}

\section{Egg-bearing females}

A total of 164 individuals of C. macrotelsonis were collected, representing 67 males (40.9\%), 94 females (57.3\%), and 3 damaged specimens (1.8\%) which could not be sexed. A total of $26.6 \%$ (25 individuals) of the collected females were ovigerous. Egg-bearing females were obtained during all months of the study period (with the exception of May 2008). Monthly percentage of ovigerous females in relation of total females varied between 13.8\% (July 2009; $n=4$ ) and 100.0\% (March 2009; $n=3$ ) (Table 1). Most of eggbearing females ( 11 out of 25 individuals) were obtained during the November2008 sampling (Table 1), the month with the lowest temperature (Fig. 2). Between November 2008 and March 2009, the number of ovigerous females decreased with increasing temperature (Fig. 2). 
Table 1. Callichirus macrotelsonis females collected between September 2008 and July 2009 at Perequê-açu beach, Ubatuba/SP, Brazil. The percentage of ovigerous females is indicated.

\begin{tabular}{lccc}
\hline \multirow{2}{*}{ Collection date } & \multicolumn{3}{c}{$\mathbf{N}^{\circ}$. of specimens } \\
\cline { 2 - 4 } & Females & Ovigerous & (\%) \\
\hline September 2008 & 9 & 2 & 22.2 \\
November & 26 & 11 & 42.3 \\
January 2009 & 13 & 5 & 38.5 \\
March & 3 & 3 & 100 \\
May & 14 & 0 & 0 \\
July & 29 & 4 & 13.8 \\
\hline Total & 94 & 25 & 26.6 \\
\hline
\end{tabular}

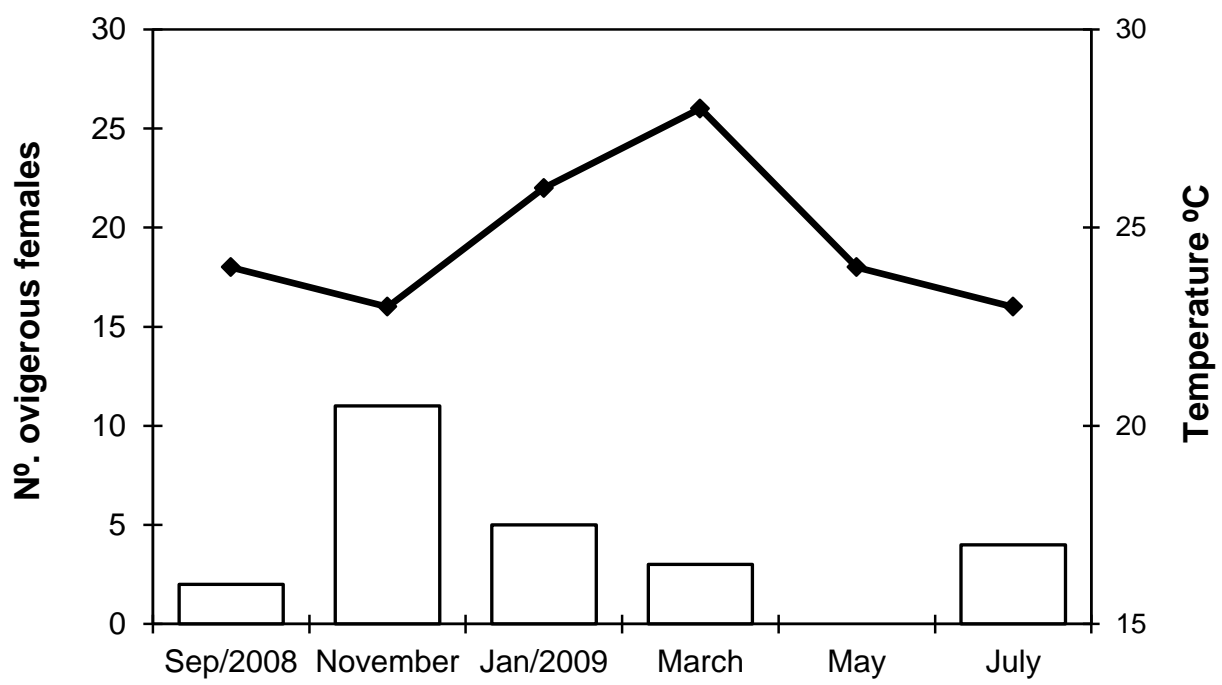

Figure 2. Bimonthly variation in number of ovigerous females of Callichirus macrotelsonis (bars) and water temperature $\left({ }^{\circ} \mathrm{C}\right)$ (line). Temperature values were obtained before each collection during September 2008 and July 2009 at Perequê-açu Beach, Ubatuba/SP, Brazil. 
Egg-bearing females measured on average $13.03 \pm 1.24 \mathrm{~mm} \mathrm{CL}$, ranging from 10.3 to $15.0 \mathrm{~mm} \mathrm{CL}$ (Fig. 3). The majority of ovigerous females (53.3\%) were in the size class of 13.0-14.3 mm CL (Fig. 3), and the smallest female with eggs measured $10.3 \mathrm{~mm} \mathrm{CL}$. The size-frequency distribution of ovigerous females presented a unimodal pattern and a normal distribution (Shapiro-Wilk, $P=$ $0.113)$

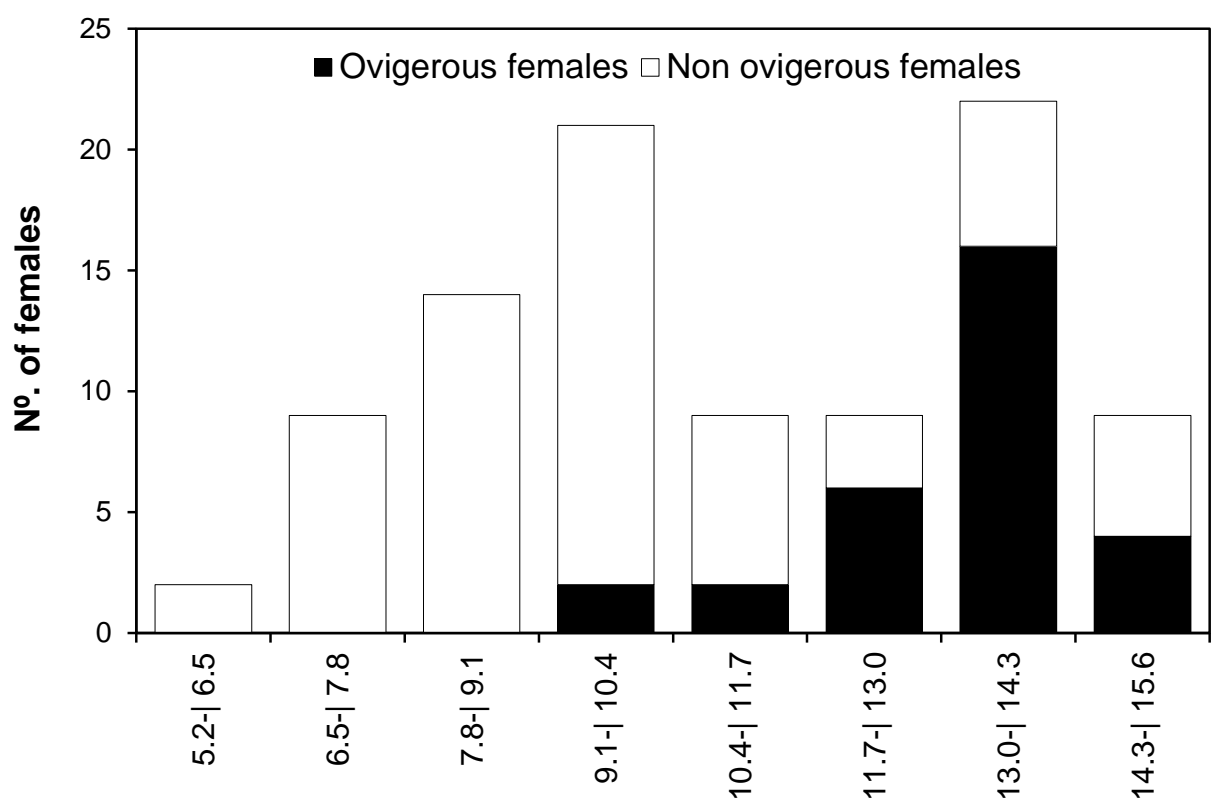

Carapace oval area length $(\mathrm{mm})$

Figure 3. Distribution frequency in size classes of non ovigerous ( $n=94$ ) and ovigerous females ( $n=25$ ) of Callichirus macrotelsonis, collected between September 2008 and July 2009 at Perequê-açu beach, Ubatuba/SP, Brazil.

The size at maturity, using the ratio $A W / C L$ versus $C L$ and separating mature females with ratios $\geq 0.97$, was reached at sizes $\geq 11.85 \mathrm{~mm} \mathrm{CL}$ (Fig. 4). The values of ratio and size were chosen by visualization of dispersion points from the relations in Fig. 4 and by the sizes of ovigerous females. 


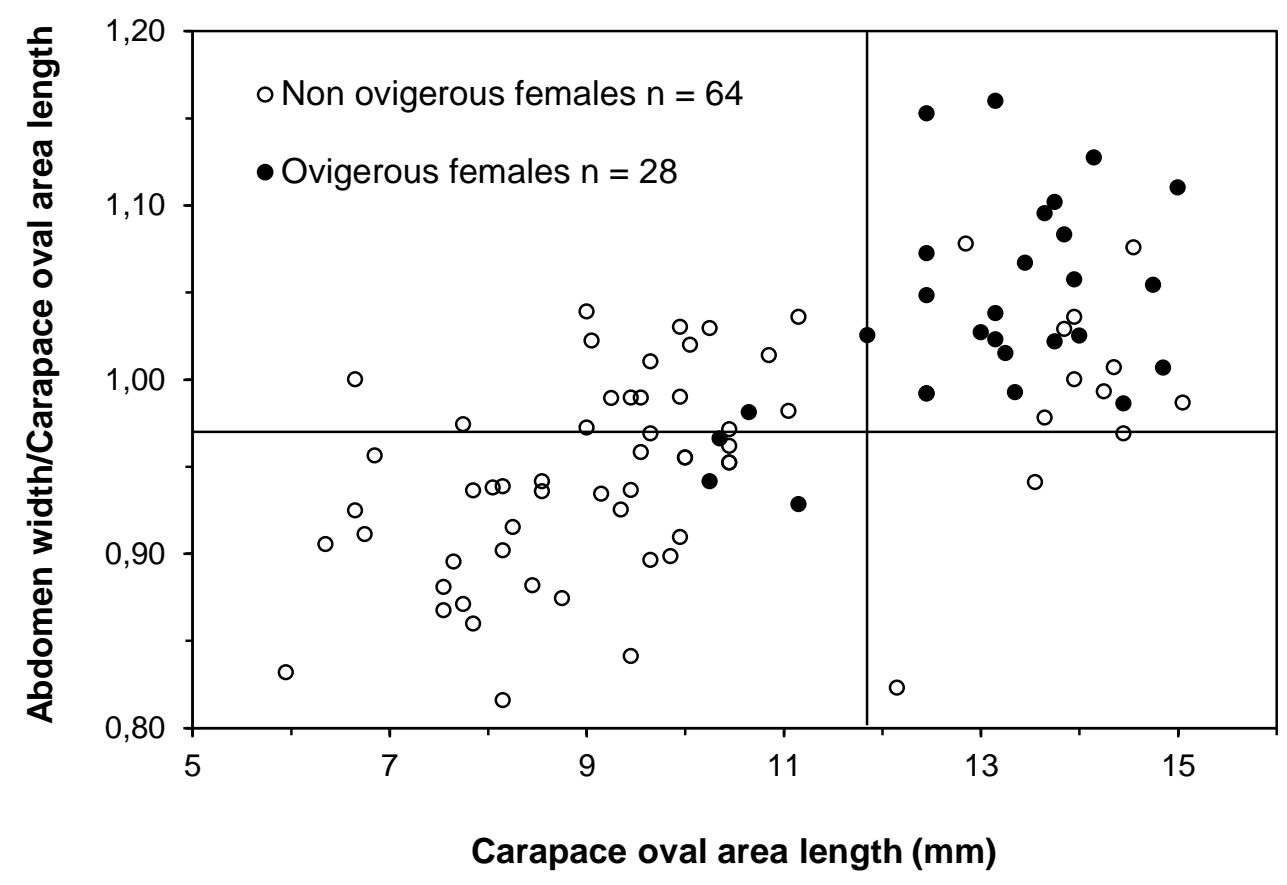

Figure 4. Ratios between abdomen width/carapace oval area length versus the carapace oval area length of Callichirus macrotelsonis, collected between September 2008 and July 2009 at Perequê-açu beach, Ubatuba/SP, Brazil. The upper right quadrant represents the higher concentrations of morphologically mature females.

\section{Egg production}

All three developmental stages were obtained in the material analyzed: $36.7 \%(n=9)$ of the females were carrying Stage-l eggs, $26.7 \%(n=7)$ eggs in Stage II, and $36.7 \%(n=9)$ eggs in Stage III (Table 2). We did not find females with egg in different developmental stages in the same egg batch. 
Table 2. Embryonic developmental stage of Callichirus macrotelsonis collected during September 2008 and July 2009 at Perequê-açu beach, Ubatuba/SP, Brazil.

\begin{tabular}{lcccc}
\hline \multirow{2}{*}{ Collection date } & \multicolumn{2}{c}{ Embryonic developmental stage } & \multirow{2}{*}{ Total } \\
\cline { 2 - 4 } & Stage I & Stage II & Stage III & \\
\hline September 2008 & 2 & 0 & 0 & 2 \\
November & 2 & 4 & 5 & 11 \\
January 2009 & 3 & 1 & 1 & 5 \\
March & 1 & 0 & 2 & 3 \\
May & 0 & 0 & 0 & 0 \\
July & 1 & 2 & 1 & 4 \\
\hline Total & $9(36.7 \%)$ & $7(26.7 \%)$ & $9(36.7 \%)$ & 25 \\
\hline
\end{tabular}

Average fecundity (based on 11 females with recently extruded eggs) was $4565 \pm 2689$ eggs, ranging from 1455 (10.35 mm CL) to 9931 (14.85 mm CL). Egg number increased significantly with female size $\left(r^{2}=0.9381 ; P<0.05\right)$ (Fig. 5). Egg loss was moderate at the beginning of the incubation period ( $15 \%$ egg loss between Stage I and II) and pronounced considering the entire embryogenesis (55\% eggs loss between Stage I and III). Mean female size did not vary significantly among the three stages of embryo development (KruskalWallis, $P=0.157)$, but the mean egg number decreased significantly with the embryonic development (Kruskal-Wallis, $P=0.157$ ). 


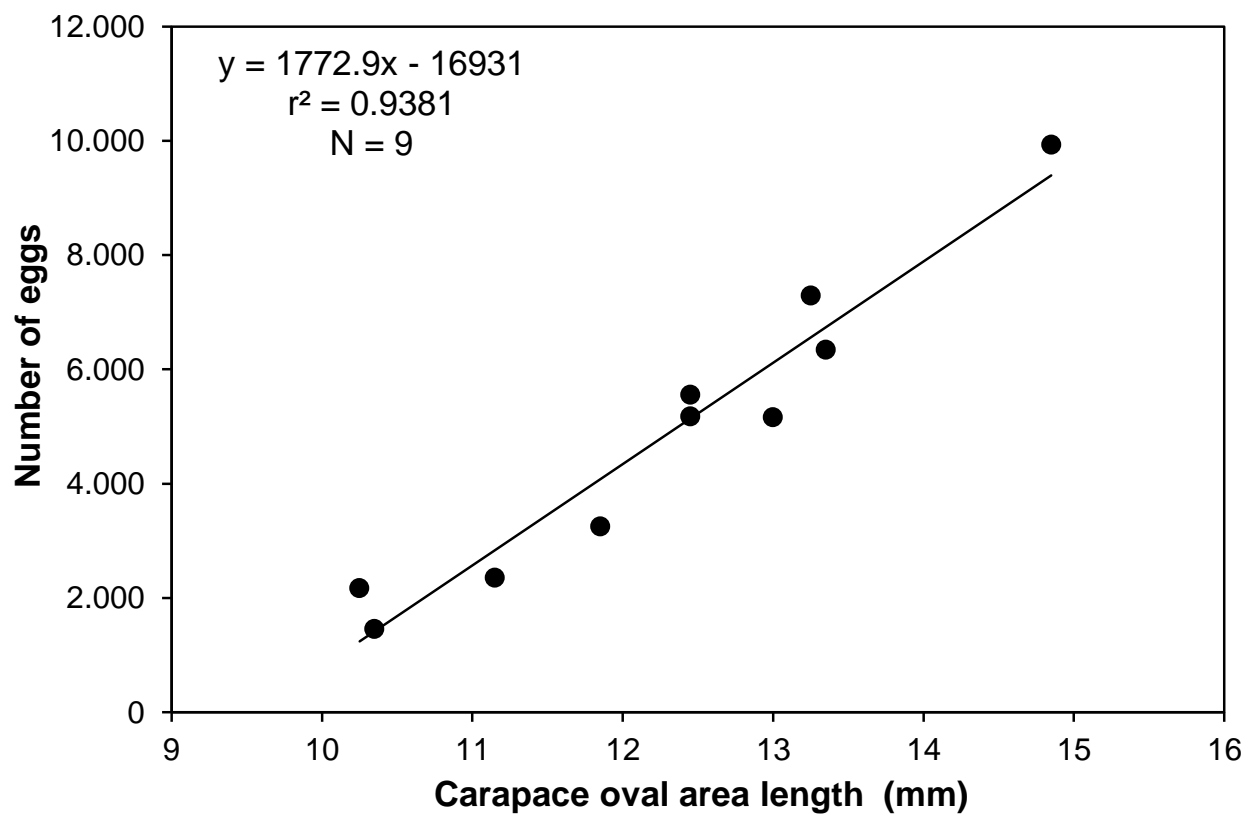

Figure 5. Relation between the number of eggs (Stage I) and the carapace oval area length of ovigerous females of Callichirus macrotelsonis, collected between September 2008 and July 2009 at Perequê-açu beach, Ubatuba/SP, Brazil.

The shape of the eggs changed during embryogenesis from almost spherical to ellipsoid. Egg volume (Table 3) increased from $0.162 \mathrm{~mm}^{3}$ (Stage I) to $0.313 \mathrm{~mm}^{3}$ (Stage III), representing an overall increase of $93.4 \%$. Egg volume increase was more pronounced between the intermediate and the final stage of embryogenesis (71.6\%) than during the early and the intermediate developmental stage (12.7\%) (Table 3). Average egg volume of all three developmental stages was significantly different (ANCOVA, F: 14.22, $P<0.001$ ). A posteriori Tukey test revealed significant differences between the egg volume in Stage I and II versus those close to hatching (Stage III; $P<0.001$ ). 
Table 3. Variation of egg size and egg volume of Callichirus macrotelsonis during embryogenesis, collected between September 2008 and July 2009 at Perequê-açu beach, Ubatuba/SP, Brazil.

\begin{tabular}{|c|c|c|c|c|c|}
\hline & \multicolumn{2}{|c|}{ Egg size (mm) } & \multicolumn{2}{|c|}{ Egg volume $\left(\mathrm{mm}^{3}\right)$} & \multirow[b]{2}{*}{$n$} \\
\hline & Egg length & Egg width & Mean & $\pm S D$ & \\
\hline Stage I & 0.71 & 0.63 & 0.162 & 0.0355 & 11 \\
\hline Stage II & 0.75 & 0.65 & 0.182 & 0.0291 & 8 \\
\hline Stage III & 0.92 & 0.75 & 0.313 & 0.1040 & 11 \\
\hline
\end{tabular}

\section{Composition of eggs and females}

Average wet weight of eggs was similar in Stage I and II (1.0501 and $1.0513 \mathrm{~g}$, respectively), and decreased substantially in eggs close to hatching (Stage III: 0.6206 g) (Table 4). Water was the predominant component of the eggs (Table 4): recently-produced eggs contained on average $75.0 \%$ water, while Stage III eggs showed average water content of $93.3 \%$, representing an increase of $24.4 \%$ during embryogenesis. In contrast, organic matter decreased during embryogenesis from $0.2477 \mathrm{~g}(94.3 \%$ of DW in Stage I) to $0.0328 \mathrm{~g}(79.3 \%$ of DW in Stage III) (Table 4). Average percentage of ash content increased steadily from $5.7 \%$ (Stage I) to $20.7 \%$ (Stage III; Table 4).

Water constituted on average $78.6 \%$ of the WW (Table 5) of female C. macrotelsonis. Organic matter and ash content accounted for $71.5 \%$ and $28.5 \%$, respectively, of the female DW (Table 5). 
Table 4. Variation in chemical composition during the embryonic development of Callichirus macrotelsonis (collected between September 2008 and July 2009 at Perequê-açu beach, Ubatuba/SP, Brazil).

\begin{tabular}{|c|c|c|c|c|c|c|c|c|c|c|c|c|}
\hline & \multicolumn{12}{|c|}{ Embryonic development } \\
\hline & \multicolumn{4}{|c|}{ Stage I } & \multicolumn{4}{|c|}{ Stage II } & \multicolumn{4}{|c|}{ Stage III } \\
\hline & Mean & $\pm S D$ & $\%$ & $n$ & Mean & \pm SD & $\%$ & $n$ & Mean & \pm SD & $\%$ & $n$ \\
\hline Wet weight (g) & 1.0501 & 0.6987 & - & 11 & 1.0513 & 0.4097 & - & 8 & 0.6206 & 0.7028 & - & 11 \\
\hline Dry weight (g) & 0.2627 & 0.2254 & - & 11 & 0.1748 & 0.0793 & - & 8 & 0.0413 & 0.0368 & - & 11 \\
\hline Water content (g) & 0.7874 & 0.4914 & 75.0 & 11 & 0.8766 & 0.3443 & 83.4 & 8 & 0.5793 & 0.6715 & 93.3 & 11 \\
\hline Organic matter (g) & 0.2477 & 0.2146 & 94.3 & 11 & 0.1601 & 0.0752 & 91.6 & 8 & 0.0328 & 0.0301 & 79.3 & 11 \\
\hline Ash content (g) & 0.0150 & 0.0123 & 5.7 & 11 & 0.0147 & 0.0080 & 8.4 & 8 & 0.0085 & 0.0074 & 20.7 & 11 \\
\hline
\end{tabular}
$\mathrm{SD}=$ standard deviation, $n=$ number of ovigerous females

Table 5. Size $(\mathrm{CL})$ and chemical composition of ovigerous females of Callichirus macrotelsonis, collected between September 2008 and July 2009 at Perequêaçu beach, Ubatuba/SP, Brazil).

\begin{tabular}{lccccc}
\hline & \multicolumn{5}{c}{ Ovigerous females } \\
\cline { 2 - 6 } & Mean & \pm SD & Minimum & Maximum & $\boldsymbol{n}$ \\
\hline CL (mm) & 13.11 & 1.29 & 10.25 & 15.35 & 30 \\
Wet weight (g) & 6.2589 & 1.6873 & 2.0728 & 9.7604 & 30 \\
Dry weight (g) & 1.3379 & 0.3999 & 0.4183 & 2.0774 & 30 \\
Water content (g) & 4.9210 & 1.4051 & 1.6545 & 7.6830 & 30 \\
Water content (\%) & 78.6 & 4.1 & 69.9 & 85.5 & 30 \\
Organic matter (g) & 0.9561 & 0.3091 & 0.2473 & 1.4862 & 30 \\
Organic matter (\%) & 71.5 & 5.3 & 58.6 & 77.9 & 30 \\
Ash content (g) & 0.3819 & 0.1190 & 0.1345 & 0.6823 & 30 \\
Ash content (\%) & 28.5 & 5.3 & 22.1 & 41.4 & 30 \\
\hline \multicolumn{4}{c}{ SD = standard deviation, $n=$ number of ovigerous females }
\end{tabular}




\section{Reproductive output}

Based on dry weight and considering exclusively recently extruded eggs, the average RO of $C$. macrotelsonis was $0.227( \pm 0.1406)$. The egg mass comprised on average $13.2 \%$ of the dry body weight of females. The RO was weakly related to the size of ovigerous females $\left(r^{2}=0.414, P<0.05\right)$ (Fig. 6).

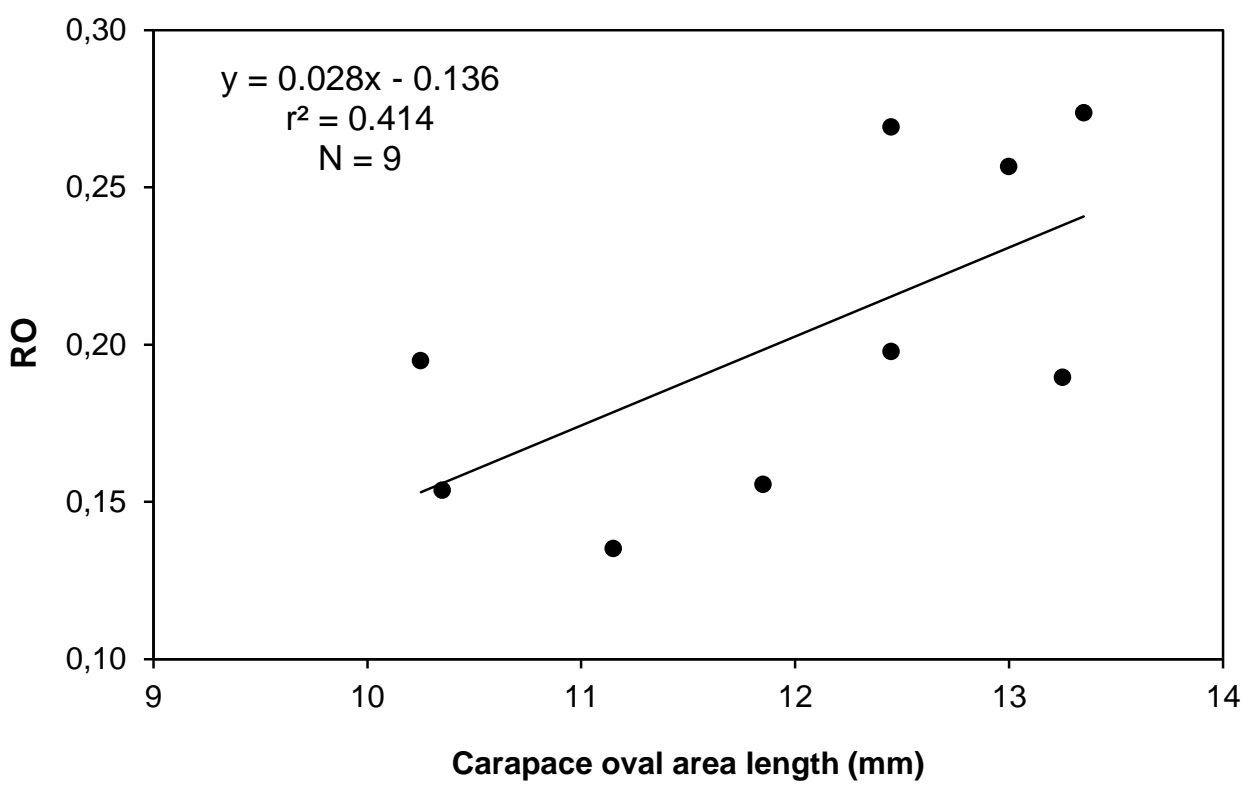

Figure 6. Relation between reproductive output (RO) and the carapace oval area length of ovigerous females of Callichirus macrotelsonis (collected between September 2008 and July 2009 at Perequê-açu beach, Ubatuba/SP, Brazil). 


\section{Discussion}

Ovigerous females of ghost shrimps constitute usually a low proportion of the total number of collected specimens (e.g., Biffarius filholi (A. MILNE-EDWARDS, 1878) as Callianassa filholi: Berkenbusch and Rowden 2000; Callichirus seilacheri (BOTt, 1955): Hernáez et al. 2008; Callichirus macrotelsonis as "C. major": BotterCarvalho et al. 2007; Ramos et al. 2007). The same tendency was also observed in the present study, and the proportion of ovigerous females $115.2 \%$ of the total number of specimens collected) was in the mid-range of the reported values in the above-mentioned studies. Egg-bearing females might be located deeper in the burrow, thus more difficult to capture with the yabby pump. Moreover, the male might fertilize only one or a reduced number of females during occasional mating events, which might result in a relatively low abundance of ovigerous females (Hernáez et al. 2008). The burrowing life style may hinder possible encounters between males and females, and this scenario may also explain the low number of ovigerous females. Independent of the underlying reasons for the general tendency of low frequency of egg-bearing females in a given population of ghost shrimps, we are convinced that the present data set provides representative information on the reproduction of the C. macrotelsonis population in Perequê-açú beach, Brazil.

Our results indicate a continuous reproduction of C. macrotelsonis in the study area (Fig. 2). Ovigerous females occurred year-round, with the exception of May 2009. Such a continuous reproduction has been reported also for other C. macrotelsonis populations along the Brazilian coast (Table 6; all signed as C. major). However, several populations seem to have more restricted reproduction periods (Table 6), but no clear latitudinal pattern is obvious when comparing the published data concerning C. macrotelsonis. It is assumed that 
local environmental conditions (especially temperature) may influence the (seasonal) occurrence of egg-bearing females of C. macrotelsonis as observed in other decapods (e.g., Baver 1992; Lardies and Castilla 2001; Terossi et al. 2010; Wehrtmann et al. 2012).

Table 6. Reproductive features of some reported populations of Callichirus macrotelsonis in different latitudes in Brazil. CL: carapace oval area length; *: \% ovigerous from total females; na: not available

\begin{tabular}{|c|c|c|c|c|c|c|c|c|}
\hline $\begin{array}{l}\text { State locality } \\
\text { in Brazil } \\
\text { (Latitude) }\end{array}$ & $\begin{array}{l}\text { Smallest and } \\
\text { biggest } \\
\text { ovigerous } \\
\text { (CL mm) }\end{array}$ & $\begin{array}{l}\text { Mean size of } \\
\text { ovigerous } \\
\text { (CL mm) }\end{array}$ & $\begin{array}{l}\% \text { of } \\
\text { ovigerous } \\
\text { from total }\end{array}$ & $\begin{array}{l}\text { Reproductive } \\
\text { Period }\end{array}$ & $\begin{array}{l}\text { Number of } \\
\text { Eggs } \\
\text { (min-max) }\end{array}$ & $\begin{array}{l}\text { Mean } \\
\text { fecundity } \\
\text { ( } \pm \text { sd) }\end{array}$ & $\begin{array}{l}\text { Water } \\
\text { temperature } \\
\left({ }^{\circ} \mathrm{C}\right)\end{array}$ & Reference \\
\hline $\begin{array}{l}\text { Pernambuco } \\
\left(8^{\circ} 11^{\prime} S\right)\end{array}$ & $7.2-12.62$ & - & 11 & $\begin{array}{l}\text { Continuous } \\
\text { (Aug-Sep gap) } \\
\text { (Dec-May peak) }\end{array}$ & $670-3530$ & - & $26-31$ & $\begin{array}{l}\text { Botter-Carvalho } \\
\text { et al. (2007) }\end{array}$ \\
\hline $\begin{array}{l}\text { Rio de Janeiro } \\
\left(22^{\circ} 46^{\prime} S\right)\end{array}$ & - & $10.43 \pm 1.91$ & $9.16^{*}$ & $\begin{array}{l}\text { Sep-Mar } \\
\text { (Nov-Jan peak) }\end{array}$ & $220-4526$ & $1913 \pm 1109$ & - & $\begin{array}{l}\text { Simão et al. } \\
\text { (2006); Ramos } \\
\text { et al. (2007) }\end{array}$ \\
\hline $\begin{array}{l}\text { São Paulo } \\
\left(23^{\circ} 24^{\prime} S\right)\end{array}$ & $10.3-15.0$ & $13.03 \pm 1.24$ & 15.2 & $\begin{array}{l}\text { Continuous } \\
\text { (May gap) } \\
\text { (Nov-Jan peak) }\end{array}$ & $1455-9931$ & $4565 \pm 2689$ & $23-28$ & Present study \\
\hline $\begin{array}{l}\text { São Paulo } \\
\left(23^{\circ} 49^{\prime} S\right)\end{array}$ & $10.3-15 \sim$ & - & - & Aug-Dec & - & - & $20-27$ & Shimizu (1997) \\
\hline $\begin{array}{l}\text { São Paulo } \\
\text { (23도's) }\end{array}$ & - & - & - & $\begin{array}{l}\text { Continuous } \\
\text { (Dec-May peak) }\end{array}$ & - & - & - & $\begin{array}{l}\text { Rodrigues and } \\
\text { Shimizu (1997) }\end{array}$ \\
\hline
\end{tabular}

Most ovigerous females of $\mathrm{C}$. macrotelsonis were collected in the month with the coolest water temperature (November; Fig. 2), and the obtained data seem to indicate an inverse relationship between the presence of egg-bearing females and temperature. Our results are in accordance to similar findings in the Pacific species C. seilacheri from Chile (Hernáez et al. 2008). The synchronization of reproduction with temperature cycles is a well-documented phenomenon in decapods (e.g., Baver 1992; Baver 2002, Castilho et al. 2007, Peiró and Mantelatto 2011), and the presence of ovigerous females carrying 
well-developed embryos at the end of cold-water periods ("winter") may suggest that larvae hatch at increasing water temperatures, typically associated with high primary production in southeastern Brazil, where the coastal water temperature reach minimum values of $15^{\circ} \mathrm{C}$ during spring and early summer due to upwelling events of the South Atlantic Central Water (SACW) (Castro-Filho et al. 1987). During the intrusion of SACW in the Ubatuba region, chlorophyll increases (Vega-Pérez 1993), and the increase in primary production may stimulate subsequent production of herbivorous zooplankton (Castilho et al. 2007). The coupling of larval hatching with increased food availability may favor the survival of planktotrophic larvae (Wear 1974; HoeghGuldberg and Pearse 1995). We noticed a high proportion of females with welldeveloped embryos (Stage II and Stage III) in November (Table 2), which supports the scenario of carrying embryos ready to hatch at the end of the coldwater period. However, additional (plankton) studies are necessary to substantiate the assumption of synchronization between egg production and water temperature in C. macrotelsonis.

The size of egg-bearing females in C. macrotelsonis differs among populations studied along the Brazilian coast (Table 6). Ovigerous females collected by us were in the size range reported from other populations in the geographic vicinity of our study area (Table 6). The interpopulational comparison (Table 6) revealed that ovigerous females were substantially smaller in the northern population (Pernambuco) compared to the populations in more southern locations (Table 6). Intraspecific variability of the size at first maturity has been documented for a variety of decapods, assuming that higher water temperatures favor earlier gonad maturation (Poulin 1995; Lardies and Castilla 2001). Consequently, Botter-Carvalho et al. (2007) attributed the 
earlier sexual maturity of C. macrotelsonis to the higher water temperatures in Pernambuco (811's).

The data of the present study do not allow any solid conclusion about the number of broods per year in C. macrotelsonis. Females with recentlyproduced embryos were present practically in all months (Table 2), which may suggest that females can produce a second brood in the same year, an assumption supported by Botter-Carvalho et al. (2007), who also mentioned the possibility of having two breeding events in C. macrotelsonis in a short period of time. This conclusion finds further support by the fact that embryonic development in the laboratory lasts 32 days at temperatures about $23^{\circ} \mathrm{C}$ (Rodrigues 1976).

The fecundity of C. macrotelsonis from Perequê-açu beach is considerably higher when compared to published data from other populations (1455-9931 eggs) (Table 6). This result is probably related to the fact that we analyzed larger females than the other studies. As a general trend in decapods, egg number increases with female size (Terossi et al. 2010; Peiró and Mantelatto 2011). Our results regarding C. macrotelsonis corroborate this positive relation (Fig. 5). A strong correlation between number of eggs and CL was also found in C. seilacheri $\left(r^{2}=0.80\right.$, Hernáez et al. 2008). However, data concerning other ghost shrimps (B. filholi: Berkenbusch and Rowden 2000; Pestarella tyrrhena (PETAGNA, 1792) as Callianassa tyrrhena: Thessalou-Legaki and Kiortsis 1997), as well as other C. macrotelsonis populations (Souza et al. 1998; Botter-Carvalho et al. 2007, as C. major) did not reveal such a strong correlation between the two factors.

Egg loss (55\%) during embryogenesis was more pronounced in $\mathrm{C}$. macrotelsonis as compared to Pacific species C. seilacheri $18.6 \%$ egg loss, and 
40\% volume increasing: Hernáez et al. 2008), Calocaris macandrae (66\%; Buchanan 1963) and other decapods (for review, see Kuris 1991). The considerable loss of embryos in C. macrotelsonis is associated with a concomitant substantial increase of the egg volume, which almost doubled during the incubation period (93.4\%) (Table 3). It is therefore assumed that the swelling embryos outgrow the limited space of the attachment area, which in turn favors the physical abrasion of these eggs (Kuris 1991), especially when considering the burrowing life style of these ghost shrimp. According to Thessalou-Legaki and Kiortsis (1997), P. tyrrhena is in permanent contact with the burrow walls, which may favor egg loss as observed in the present study.

The egg length of $C$. macrotelsonis $(0.75-0.92 \mathrm{~mm})$ is relatively low when compared to callianassids as Callichirus kraussi (SteBBING, 1900) as Callianassa kraussi (1.52 mm; Forbes 1973), P. tyrrhena (1.18 mm; Thessalou 1987), and Lepidophthalmus sinuensis LEMAITRE \& RODRIGUES, 1991 (1.22 mm; Nates and Felder 1999). According to Rodrigues (1976; 1984), the larval development in C. macrostelsonis comprises four larval stages. The relative small egg size suggests an extended planktotrophic phase, while the above-mentioned callianassids have an abbreviated larval development.

The water content of C. macrotelsonis eggs increased during embryogenesis from $75.0 \%$ to $93.3 \%$ (Table 5). This steady increase is in accordance with similar findings from other decapods (Lardies and Wehrtmann 1996, 1997; Wehrtmann and Kattner 1998; Wehrtmann et al. 2012). Moreover, our results provide further support for the hypothesis (see Pandian 1970) that benthic species with pelagic larval stages have lower egg water content than pelagic species with pelagic larvae (roughly $60 \%$ versus $90 \%$, respectively). On the other hand, we observed an increase of ash content accompanied by a 
concomitant decrease of the organic matter of developing eggs (Table 5). Such a pattern has been observed also in other decapods (Pandian 1970; Amsler and George 1984; Valdés et al. 1991; Lardies and Wehrtmann 1997, 2001; Urzúa et al. 2012) and seems to be a general feature for the development of estuarine-marine decapod eggs.

Females of C. macrotelsonis inverted $13.2 \%$ of their body dry weight in egg production. This value is slightly lower than that reported for C. seilacheri (14.9\%, Hernáez et al. 2008) and P. tyrrhena (19.6\%, Thessalou-Legaki and Kiortsis 1997), but within the range of above reported axiid species. The few published data on RO values seem to suggest that female investment in reproduction of axiidean shrimps is somewhat higher than in other decapods, where brood weight is constrained generally to about $10 \%$ of female body weight, ranging from 3 to $22 \%$ (Hines 1991 ; 1992).

The high investment in egg production is probably an effort to maximize the viability of the progeny; once the males can fertilize only one or a reduced number of females, and also due to the occasional meetings between couples males and females in the sand, resulting in a relatively low abundance of ovigerous females compared other decapods. Our results provide valuable information on the reproductive biology of C. macrotelsonis, which, together data from other studies on ghost shrimps, may help to understand the evolution and ecology of reproduction of these crustaceans. However, studies with additional species will be necessary in order to clarify whether there exist a tendency of axiidean shrimps to have RO values at the upper end of the range reported for decapods. 


\section{Acknowledgments}

This study formed part of a PhD thesis by DFP, and was supported by a fellowship from CNPq-Brazil (Conselho Nacional de Desenvolvimento Científico e Tecnológico) - Grants GD 141446/2009-9 and SWE 201831/2010-4. FLM is grateful to CNPq for an ongoing research grant (302748/2010-5). FLM and ISW are grateful for the support of their bilateral projects financed by CNPq (491490/2004-6; 490122/2006-0; 490353/2007-0) and CONICIT (Costa Rica). Additional support for this study was provided by funding from the CNPa (471794/2006-6; 301359/2007-5; 473050/2007-2) and FAPESP (Fundação de Amparo à Pesquisa do Estado de São Paulo) (Temático Biota 2010/50188-8; Coleções Científicas 2009/54931-0) to FLM. Special thanks are due to Raquel C. Frozoni, Denis A. Peiró, Ricardo R. Ribeiro da Silva, and to all members of the Laboratory of Bioecology and Crustacean Systematics of FFCLRP/USP for their help during field and laboratory work. The support of the Graduate Program in Comparative Biology of FFCLRP/USP and of the Centro de Biologia Marinha da USP - CEBIMar/USP during the collections is also acknowledged. All experiments conducted in this study complied with current applicable state and federal laws of Brazil (n 126/05 DIFAP/IBAMA). 


\section{References}

Abrunhosa FA, Arruda DCB, Simith DJB, Palmeira CAM. 2008. The importance of feeding in the larval development of the ghost shrimp Callichirus major (Decapoda: Callianassidae). Anais da Academia Brasileira de Ciências, 80: 445-453.

Abu-Hilal A, Bachan M, De Vaugelas J. 1988. Distribution of trace elements in Callichirus laurae burrows and nearby sediments in the Gulf of Aqaba, Jordan (Red Sea). Marine Environmental Research, 25: 233-248.

Amsler, MO, George RY. 1984. Seasonal variation in the biochemical composition of the embryos of Callinectes sapidus Rathbun. Journal of Crustacean Biology, 4: 546-553.

Baver RT. 1992. Testing generalizations about latitudinal variation in reproduction and recruitment patterns with sicyoniid and caridean shrimp species. Invertebrate Reproduction \& Development, 22: 193-202.

Baver RT. 2002. Reproductive ecology of a protandric simultaneous hermaphrodite, the shrimp Lysmata wurdemanni (Decapoda: Caridea: Hippolytidae). Journal of Crustacean Biology, 22: 742-749.

Berkenbusch K, Rowden AA. 2000. Latitudinal variation in the reproductive biology of the burrowing ghost shrimp Callianassa filholi (Decapoda: Thalassinidea). Marine Biology, 136: 497-504.

Berkenbusch K, Rowden AA. 2003. Ecosystem engineering - moving away from 'just-so' stories. New Zealand Journal of Ecology, 27: 67-73.

Boolootian RA, Giese AC, Farmanfarmain A, Tucker J. 1959. Reproductive cycles of five west coast crabs. Physiological Zoology, 32: 213-220.

Botter-Carvalho ML, Santos PJP, Carvalho PVVC. 2007. Population dynamics of Callichirus major (Say, 1818) (Crustacea, Thalassinidea) on a beach in northeastern Brazil. Estuarine Coastal and Shelf Science, 71: 508-516.

Branch GM, Pringle A. 1987. The impact of the sand prawn Callianassa kraussi Stebbing on sediment turnover and on bacteria, meiofauna, and benthic microflora. Journal of Experimental Marine Biology and Ecology, 107: 219-235.

Buchanan J. 1963. The biology of Calocaris macandrae (Crustacea, Thalassinidea). Journal of the Marine Biological Association of the United Kingdom, 43: 729-747.

Castilho AL, Gavio MA, Costa RC, Boschi EE, Baver RT, Fransozo A. 2007. Latitudinal Vvariation in population structure and reproductive pattern of the endemic South American shrimp Artemesia longinaris (Decapoda: Penaeoidea). Journal of Crustacean Biology, 27: 548-552. 
Castro-Filho BM, Miranda LB, Myao Y. 1987. Condições hidrográficas na plataforma continental ao largo de Ubatuba: variações sazonais e em média escala. Boletim do Instituto Oceanográfico, 35: 135-151.

Clarke A. 1987. Temperature, latitude and reproductive effort. Marine Ecology Progress Series, 38: 89-99.

Clarke A, Hopkins CCE, Nilssen EM. 1991. Egg size and reproductive output in the deep water prawn Pandalus borealis (Kroyer, 1838). Functional Ecology, 5: 724-730.

Cobo VJ, Okamori CM. 2008. Fecundity of the spider crab Mithraculus forceps (Decapoda, Mithracidae) from the northeastern coast of the state of São Paulo, Brazil. Iheringia, Série Zoologia, 98: 84-87.

Colpo KD, Negreiros-Fransozo ML. 2003. Reproductive output of Uca vocator (Herbst, 1804) (Brachyura, Ocypodidae) from three subtropical mangroves in Brazil. Crustaceana, 76: 1-11.

Dworschak PC. 2000. Global diversity in the Thalassinidea (Decapoda). Journal of Crustacean Biology, 20: 238-245.

Forbes AT. 1973. An unusual abbreviated larval life in the estuarine burrowing prawn Callianassa kraussi (Crustacea, Decapoda, Thalassinidea). Marine Biology, 22: 361-365.

Giese AC. 1959. Comparative physiology: annual reproductive cycles of marine invertebrates. Annual Review of Physiology, 21: 547-576.

Griffis RG, Suchanek TH. 1991. A model of burrow architecture and trophic modes in thalassinidean shrimp (Decapoda: Thalassinidea). Marine Ecology Progress Series, 79: 171-183.

Hammer $\varnothing$, Harper DAT, Ryan PD. 2001. Past: Paleontological Statistics Software Package for Education and Data Analysis. Paleontologia Eletronica, 4: $1-9$.

Hernáez P, Palma S, Wehrtmann IS. 2008. Egg production of the burrowing shrimp Callichirus seilacheri (Bott 1955) (Decapoda, Callianassidae) in northern Chile. Helgoland Marine Research, 62: 351-356.

Hines $\mathrm{AH}$. 1982. Allometric constraints and variables of reproductive effort in brachyuran crabs. Marine Biology, 69: 309-320.

Hines AH. 1991. Fecundity and reproductive output in nine species of Cancer crabs (Crustacea, Brachyura, Cancridae). Canadian Journal of Fisheries and Aquatic Sciences 48, 267-275.

Hines AH. 1992. Constraint of reproductive output in brachyuran crabs: pinnotherids test the rule. American Zoologist, 32: 503-51 1. 
Hoegh-Guldberg O, Pearse JP. 1995. Temperature, food availability, and the development of marine invertebrate larvae. American Zoologist, 35: 415-425.

Hughes DJ. 2000. A field test of the effects of megafaunal burrows on benthic chamber measurements of sediment-water solute fluxes. Marine Ecology Progress Series, 195: 189-199.

Itani G. 2004. Host specialization in symbiotic animals associated with thalassinidean shrimps in Japan. In Tamaki A, editor. Proceedings of the symposium on "Ecology of large bioturbators in tidal flat and shallow sublittoral sediments - from individual behaviour to their role as ecosystem engineers". 1-2 Nov. 2003, Nagasaki University, Nagasaki, Japan, pp. 33-44.

Itani G, Kato M. 2002. Cryptomya (Venatomya) truncata (Bivalvia: Myidae): association with thalassinidean shrimp burrows and morphometric variation in Japanese waters. Venus, 61: 193-202.

Jones MB, Simons MJ. 1983. Latitudinal variation in reproductive characteristics of a mud crab, Helice crassa (Grapsidae). Bulletin of Marine Science, 33: 656-670.

Kuris A. 1991. A review of patterns and causes of crustacean brood mortality. In Schram FR, editor. Crustacean issues. Vol. 7, Balkema, Rotterdam, pp. 117-141.

Lara R, Wehrtmann IS. 2009. Reproductive biology of the freshwater shrimp Macrobrachium carcinus (L.) (Decapoda, Palaemonidae) from Costa Rica, Central America. Journal of Crustacean Biology, 29: 343-349.

Lardies MA, Castilla JC. 2001. Latitudinal variation in the reproductive biology of the commensal crab Pinnaxodes chilensis (Decapoda: Pinnotheridae) along the Chilean coast. Marine Biology, 139: 1125-1133.

Lardies MA, Wehrtmann IS. 1996. Aspects of the reproductive biology of Petrolisthes laevigatus (Guérin, 1835) (Decapoda, Anomura, Porcellanidae). Part I: reproductive output and chemical composition of eggs during embryonic development. Archives of Fishery and Marine Research, 43: 121-135.

Lardies MA, Wehrtmann IS. 1997. Egg production in Betaeus emarginatus $(H$. Milne Edwards, 1837) (Decapoda: Alpheidae): fecundity, reproductive output and chemical composition of eggs. Ophelia, 46: 165-174.

Lardies MA, Wehrtmann IS. 2001. Latitudinal variation in the reproductive biology of Betaeus truncatus (Decapoda: Alpheidae) along the Chilean coast. Ophelia, 55: 55-67.

Manning RB. 1975. Two methods for collecting decapods in shallow water. Crustaceana, 29: 317-319. 
Mantelatto FL, Fransozo A. 1997. Fecundity of the crab Callinictes ornatus Ordway, 1863 (Decapoda, Brachyura, Portunidae) from the Ubatuba region, São Paulo, Brazil. Crustaceana, 70: 214-226.

Mantelatto FL, Garcia RB. 1999. Reproductive potential of the hermit crab Calcinus tibicen (Anomura) from Ubatuba, São Paulo, Brazil. Journal of Crustacean Biology, 19: 268-275.

McDermott JJ. 2006. The biology of Austinixa gorei (Manning \& Felder, 1989) (Decapoda, Brachyura, Pinnotheridae) symbiotic in the burrows of intertidal ghost shrimp (Decapoda, Thalassinidea, Callianassidae) in Miami, Florida. Crustaceana, 79: 345-361.

Melo GAS. 1999. Manual de identificação dos Crustacea Decapoda do litoral brasileiro: Anomura, Thalassinidea, Palinuridea, Astacidea. Plêiade/FAPESP, São Paulo.

Miranda I, Meireles AL, Biagi R, Mantelatto FL. 2006. Is the abundance of the red brocade hermit crab Dardanus insignis (Decapoda: Anomura: Diogenidae) in the infralittoral region of southern Brazil determined by reproductive potential? In Asakura A, editor. Biology of Anomura. Crustacean Research (Special Number), 6: 45-55.

Nates SF, Felder DL. 1999. Growth and maturation of the ghost shrimp Lepidophthalmus sinuensis Lemaitre and Rodrigues, 1991 (Crustacea, Decapoda, Callianassidae), a burrowing pest in penaeid shrimp culture ponds. Fishery Bulletin, 97: 541-562.

Pandian TJ. 1970. Ecophysiological studies on the developing eggs and embryos of the European lobster Homarus gammarus. Marine Biology, 5: 154-167.

Pavanelli CAM, Mossolin EC, Mantelatto FL. 2010. Maternal investment in egg production: environmental and population-specific effects on offspring performance in the snapping shrimp Alpheus nuttingi (Schmitt, 1924) (Decapoda, Alpheidae). Animal Biology, 60: 237-247.

Peiró DF, Mantelatto FL. 2011. Population dynamics of the pea crab Austinixa aidae (Brachyura: Pinnotheridae): a symbiotic of the ghost shrimp Callichirus major (Thalassinidea: Callianassidae) from the southwestern Atlantic. Iheringia, Série Zoologia, 101: 5-14.

Peiró DF, Baeza JA, Mantelatto FL. 2012. Host-use pattern and sexual dimorphism reveals the mating system of the symbiotic pea crab Austinixa aidae (Crustacea: Brachyura: Pinnotheridae). Journal of the Marine Biological Association of the United Kingdom, DOI $10.1017 /$ S0025315412000720

Peiró DF, Robles R, Felder DL, Mantelatto FL. Submitted. Designation of Callichirus macrotelsonis (Ortmann 1893), comb. nov. as the "Brazilian 
species" of the Callichirus major (Say 1818) complex (Decapoda: Axiidea: Callianassidae) using morphological and molecular data. Zootaxa.

Pianka ER. 1972. R and K selection or $b$ and d selection? American Naturalist, 106: 581-588.

Pinheiro MAA, Fransozo A. 1995. Fecundidade de Pachycheles haigae Rodrigues da Costa, 1960 (Crustacea, Anomura, Porcellanidae) em Ubatuba (SP), Brasil. Revista Brasileira de Biologia, 55: 623-631.

Poulin R. 1995. Clutch size and egg size in free-living and parasitic copepods: a comparative analysis. Evolution, 49: 325-336.

Ramos MF, Simão DS, Soares-Gomes A. 2007. Aspectos reprodutivos de Callichirus major (Say, 1818) (Crustacea: Thalassinidea) na Praia Rasa, Armação dos Búzios, RJ. In Anais do XII Congresso Latino-Americano de Ciências do Mar, 15-19 April 2007, Florianópolis.

Rodrigues SA. 1966. Estudos sobre Callianassa: Sistemática, Biologia e Anatomia. PhD Thesis, Faculdade de Filosofia Ciências e Letras da Universidade de São Paulo, São Paulo, Brazil.

Rodrigues SA. 1976. Sobre a reprodução, embriologia e desenvolvimento larval de Callichirus major Say, 1818 (Crustacea, Decapoda Thalassinidea). Boletim de Zoologia da Universidade de São Paulo, 1: 85-104.

Rodrigues, SA. 1983. Aspectos da biologia de Thalassinidea do Atlântico tropical americano. Livre Docência Thesis, Instituto de Biociências da Universidade de São Paulo, São Paulo, Brazil.

Rodrigues SA. 1984. Desenvolvimento pós-embrionário de Callichirus mirim (Rodrigues, 1971) obtido em condições artificiais (Crustacea, Decapoda, Thalassinidea). Boletim de Zoologia Universidade de São Paulo, 8: 239-256.

Rodrigues SA, Shimizu RM. 1997. Autoecologia de Callichirus major (Say, 1818). Oecologia Brasiliensis, 3(1): 155-170.

Sastry AN. 1983. Ecological aspects of reproduction. In Vernberg FJ, Vernberg WB, editors. The Biology of Crustacea VIII. Environmental Adaptations. Academic Press, New York, pp. 179-270.

Sendim FS, Souza GMS, Mcallan JP, Cardoso RS. 2007. Aspectos reprodutivos de Callichirus major em uma praia do Rio de Janeiro. In Anais do XII Congresso Latino-Americano de Ciências do Mar, 15-19 April 2007, Florianópolis.

Shapiro SS, Wilk MB. 1965. An analysis of variance test for normality (complete samples). Biometrika, 52 (3-4): 591-611. 
Shimizu RM. 1997. Ecologia populacional de Scolelepis squamata (Muller, 1806) (Polychaeta: Spionidae) e Callichirus major (Say, 1818) (Crustacea: Decapoda: Thalassinidae) da Praia de Barequeçaba (São Sebastião, SP). PhD Thesis, Instituto de Biociências da Universidade de São Paulo, São Paulo, Brazil.

Simão DS, Ramos MF, Soares-Gomes A. 2006. Population structure of Callichirus major (Say 1818) (Crustacea: Thalassinidea) in a sandy beach of Rio de Janeiro State, southeast Brazil coast. Journal of Coastal Research, Special Issue, 39: 1165-1168.

Souza JRBD, Borzone CA, Brey T. 1998. Population dynamics and secondary production of Callichirus major (Crustacea, Thalassinidea) on a southern Brazilian sandy beach. Archive of Fishery and Marine Research, 46: 151-164.

Staton, JL, Felder DL. 1995. Genetic variation in populations of the ghost shrimp genus Callichirus (Crustacea: Decapoda: Thalassinoidea) in the western Atlantic and Gulf of Mexico. Bulletin of Marine Science, 56: 523536.

Strasser KM, Felder DL. 1999a. Larval development of two populations of the ghost shrimp Callichirus major (Decapoda: Thalassinidea) under laboratory conditions. Journal of Crustacean Biology, 19: 844-878.

Strasser KM, Felder DL. 1999b. Settlement in an Atlantic coast population of the ghost shrimp Callichirus major (Crustacea: Decapoda: Thalassinidea). Marine Ecology Progress Series, 183: 217-225.

Sturges HA. 1926. The choice of a class interval. Journal of the American Statistical Association, 21: 65-66.

Suchanek TH, Colin PL, Mcmurtry GM, Suchanek C.S. 1986. Bioturbation and redistribution of sediment radionuclides in Enewetak atoll lagoon by callianassid shrimp: biological aspects. Bulletin of Marine Science, 38:144-154.

Tamaki A, Tanoue H, Itoh J, Fukuda Y. 1996. Brooding and larval developmental periods of the callianassid ghost shrimp, Callianassa japonica (Decapoda: Thalassinidea). Journal of the Marine Biological Association of the United Kingdom, 79: 675-689.

Terossi M, Wehrtmann IS, Mantelatto FL. 2010. Interpopulational comparison of reproduction of the Atlantic shrimp Hippolyte obliquimanus (Caridea: Hippolytidae). Journal of Crustacean Biology, 30: 571-579.

Thessalou M. 1987. Contribution to the study of ecology and biology of the shrimp Callianassa tyrrhena (Petagna, 1792) (in Greek). (Crustacea, Decapoda, Thalassinidea). Ph.D. Thesis, University of Athens, Athens, Greece. 
Thessalou-Legaki M, Kiortsis V. 1997. Estimation of the reproductive output of the burrowing shrimp Callianassa tyrrhena: a comparison of three different biometrical approaches. Marine Biology, 127: 435-442.

Timofeev SF, Sklyar VV. 2001. Egg size in the euphausiid, Thysanoessa raschii (M. Sars, 1864) (Euphausiacea) in the Barents Sea. Crustaceana, 74: 12011211.

Tinkle DW, Hadley NF. 1975. Lizard reproductive effort; caloric estimates and comments on its evolution. Ecology, 56: 427-434.

Torati LS, Mantelatto FL. 2008. Uncommon mechanism of egg incubation in the endemic southern hermit crab Loxopagurus loxochelis: how is this phenomenon related to egg production? Acta Zoologica, 89: 79-85.

Urzúa A, Paschke K, Gebaver P, Anger K. 2012. Seasonal and interannual variations in size, biomass and chemical composition of the eggs of North Sea shrimp, Crangon crangon (Decapoda: Caridea). Marine Biology, DOI 10.1007/s00227-011-1837-x

Valdés L, Alvarez-Ossorio MT, Gonzalez-Gurriarán E. 1991. Incubation of eggs of Necora puber (L., 1767) (Decapoda, Brachyura, Portunidae). Volume and biomass changes in embryonic development. Crustaceana, 60: 163-177.

Vega-Pérez LA. 1993. Estudo do zooplâncton da região de Ubatuba, Estado de São Paulo. Publicação especial do Instituto Oceanográfico, 10: 65-84.

Waslenchuk DG, Matson EA, Zajac RN, Dobbs FC, Tramontano JM. 1983. Geochemistry of burrow waters vented by a bioturbating shrimp in Bermudian sediments. Marine Biology, 72: 219-225.

Wear RG. 1974. Incubation in British decapod Crustacea, and the effects of temperature on the rate and success of embryonic development. Journal of the Marine Biological Association of the United Kingdom, 54: 745-762.

Webb AP, Eyre BD. 2004. Effects of natural populations of burrowing thalassinidean shrimp on sediment irrigation, benthic metabolism, nutrient fluxes and denitrification. Marine Ecology Progress Series, 268: 20-220.

Wehrtmann, IS, Kattner, G. 1998. Changes in volume, biomass, and fatty acids of developing eggs of Nauticaris magellanica (Decapoda; Caridea): a latitudinal comparison. Journal of Crustacean Biology, 18: 413-422.

Wehrtmann IS, Miranda I, Hernáez P, Mantelatto FL. 2012. Reproductive plasticity in Petrolisthes armatus (Anomura, Porcellanidae): a comparison between a Pacific and an Atlantic population. Helgoland Marine Research, 66: 87-96. 
Zar JH. 1996. Biostatistical Analysis. Prentice-Hall, New Jersey.

Ziebis W, Forster S, Huettel M, Jørgensen B.B. 1996. Complex burrows of the mud shrimp Callianassa truncata and their geochemical impact in the sea bed. Nature, 382: 619-622. 


\section{Capítulo III}

Dinâmica populacional de Callichirus macrotelsonis (Ortmann, 1893) (Decapoda, Axiidea, Callianassidae) na praia do Perequêaçu, Ubatuba, litoral norte do Estado de São Paulo

Artigo a ser submetido à revista Zoologia, 2012 
Dinâmica populacional de Callichirus macrotelsonis (Ortmann, 1893) (Decapoda, Axiidea, Callianassidae) na praia do Perequê-açu, Ubatuba, litoral norte do Estado de São Paulo

Douglas Fernando Peiró \& Fernando Luis Mantelatto

Laboratório de Bioecologia e Sistemática de Crustáceos (LBSC), Departamento de Biologia da Faculdade de Filosofia Ciências e Letras de Ribeirão Preto da Universidade de São Paulo, Programa de Pós-graduação em Biologia Comparada. Av. Bandeirantes 3900, 14040-901, Ribeirão Preto (SP), Brasil.

Palavras chave: corrupto de praia, complexo Callichirus major, ecologia populacional, praia arenosa. 


\section{RESUMO}

Callichirus macrotelsonis habita praias arenosas dissipativas, vivendo individualmente em galerias profundas na zona intermareal. É um importante recurso utilizado como isca, sendo que sua extração descontrolada pode causar alterações em sua estrutura populacional. Os objetivos deste estudo foram avaliar a dinâmica populacional desta espécie na praia do Perequêaçu, Ubatuba/SP, assim como a comparação dos padrões populacionais com outros estudos. Entre set/2008 e jul/2009 foram coletados bimestralmente, com bombas de sucção, 164 exemplares: 67 machos $(40,9 \%), 94$ fêmeas $(57,3 \%)$, sendo 24 ovígeras (14,6\%), e 3 indivíduos danificados (1,8\%); detectou-se uma considerável variação na abundância entre os bimestres coletados. A razão sexual foi de 1:1 entre os bimestres ( $p>0,05)$, com exceção de maio/2009. A densidade média populacional foi de 0,202 \pm 0,494 aberturas $\bullet \mathrm{m}^{-2}$. O período reprodutivo foi contínuo, com um pico sazonal em novembro. O pico de recrutamento foi inferido por meio de evidências indiretas, e ocorre entre dezembro e janeiro. A eficiência de captura foi de $26,6 \%$. Identificou-se forte influência da captura para pesca na dinâmica desta população, principalmente nos meses de verão. Além disso, foi identificado que os padrões populacionais da espécie variam consideravelmente dentro de sua ampla área de ocorrência (do Pará até Santa Catarina), o que constitui forte argumento para se incentivar estudos ecológicos em áreas onde não existem muitos destes registros, principalmente nas costas norte e nordeste do Brasil. 


\section{INTRODUÇÃO}

Os crustáceos da infraordem Axiidea (Decapoda) (juntos com Gebiidea) constituem um dos grupos mais notáveis de animais escavadores de tocas do ambiente marinho, habitando sedimentos inconsolidados nas zonas intermareal e submareal rasa (Dworschak, 1988). Podem ser encontrados em fundos de estuários, baías, lagoas costeiras, ou ao longo de praias arenosas, tanto em oceanos tropicais quanto temperados, onde escavam os maiores e mais profundos sistemas de galerias conhecidos no ambiente marinho (Abu-Hilal et al., 1988).

Dentre os Axiidea, os Callianassidae desempenham um importante papel em habitats bentônicos de sedimentos não consolidados (BotterCarvalho et al., 2007), promovendo a bioturbação, que influencia diretamente nas propriedades químicas (Waslenchuk et al., 1983; Ziebis et al., 1996, Bird et al., 2000) e físicas do sedimento (Suchanek, 1983; Suchanek \& Colin, 1986; Wynberg \& Branch, 1994). Sua atividade aumenta significativamente 0 revolvimento e retorno do sedimento e da matéria orgânica, além da ciclagem de nutrientes (Waslenchuk, et al., 1983; Branch \& Pringle, 1987; Ziebis et al., 1996; Webb \& Eyre, 2004) e a redistribuição de metais e contaminantes (Suchanek et al., 1986; Abu-Hilal et al., 1988).

Seus complexos sistemas de galerias criam, modificam, e mantém um mosaico de habitat para outros organismos (Berkenbusch \& Rowden, 2003), causando alterações na estrutura das comunidades de bactérias e animais bentônicos (Berkenbusch et al., 2000; Dworschak, 2000). Estas estruturas promovem micro-habitat favoráveis para a ocorrência da fauna associada (Berkenbusch \& Rowden, 2003), composta por caranguejos pinnoterídeos, 
bivalves, copépodes e tanaidáceos (Rodrigues \& Shimizu, 1997; Peiró \& Mantelatto 2011; Peiró et al., 2011; Peiró et al., 2012a).

Callichirus macrotelsonis (ORTMANN, 1893), até recentemente denominado Callichirus major (SAY, 1818) sensu lato (vide Capítulo I), habita o Atlântico Ocidental, do Estado do Pará ao Estado de Santa Catarina no Brasil (Melo, 1999; Abrunhosa et al., 2008). Esta espécie é encontrada em praias arenosas dissipativas (Botter-Carvalho et al., 2002; 2007) e apresenta um comportamento críptico, vivendo individualmente nas galerias profundas na zona intermareal, e também abaixo do nível médio de marés (Rodrigues \& Shimizu, 1997).

Callichirus macrotelsonis, assim como todas as espécies do complexo C. major, é um importante recurso econômico devido a sua ampla utilização como isca por pescadores em muitas áreas costeiras (Wynberg \& Branch, 1994; Contessa \& Bird, 2004; Skilleter et al., 2005). Inclusive ao longo do litoral brasileiro, com maior intensidade a partir dos anos 80 (Borzone \& Souza, 1996; Souza \& Borzone, 2003). Algumas espécies da família Callianassidae são utilizadas como isca devido a sua qualidade como tal, e pela facilidade de captura com bombas de sucção compradas facilmente em lojas especializadas em pesca (Peiró \& Mantelatto, 2011). A extração descontrolada para tal finalidade pode causar alterações em sua estrutura populacional como também na de outras espécies existentes no sedimento, incluindo as simbiontes (Wynberg \& Branch, 1991).

Na praia do Perequê-açu (Ubatuba), no litoral norte de São Paulo, está estabelecida uma população de C. macrotelsonis que vem sofrendo constante extração para sua utilização como isca a, pelo menos, 15 anos (Peiró \& Mantelatto, 2011). Neste local há uma comunidade de pescadores 
nativos que utilizam este recurso extensivamente para tal finalidade. Além disso, esta praia está localizada próxima ao centro do município, que recebe milhares de turistas (principalmente nos meses de férias de verão). Eventualmente, muitos dos turistas também extraem estes animais para pesca amadora (DFP \& FLM observação pessoal).

Alguns estudos vêm sendo realizados com C. macrotelsonis (em todos estes trabalhos anteriores, nomeado como C. major) desde Rodrigues (1966) em diversas localidades de sua área de ocorrência. Outros pesquisadores contribuíram com importantes informações, com exemplo, os trabalhos sobre aspectos populacionais e reprodutivos realizados por: Shimizu (1997); Souza et al. (1998); Shimizu \& Rosso (2000); Botter-Carvalho et al. (2007); Simão et al. (2006); Sendim et al. (2007); Ramos et al. (2007). Sobre aspectos autoecológicos: Rodrigues \& Shimizu (1997). Sobre padrões de distribuição: Botter-Carvalho et al. (2002). Sobre a exploração da espécie como isca: Souza \& Borzone (2003), entre outros. Apesar da grande literatura disponível para a espécie no Brasil, não foram encontrados trabalhos sobre sua dinâmica populacional nos limites do litoral norte do Estado de São Paulo e sul do Estado do Rio de Janeiro.

Os objetivos deste trabalho foram descrever a dinâmica populacional de C. macrotelsonis na praia do Perequê-açu, Ubatuba/SP, vislumbrando a detecção de possíveis influências no padrão populacional, assim como a comparação com outros estudos descritos na literatura científica. Os objetivos específicos foram determinar a frequência de indivíduos entre as classes de tamanho, a razão sexual, a densidade, os períodos de recrutamento e de reprodução, assim como a eficiência de captura da espécie no local. 
Considerando a diversidade morfológica intraespecífica em C. macrotelsonis ao longo de sua distribuição (Capítulo I), foi avaliada a hipótese de similaridade entre os parâmetros populacionais registradas na literatura científica - $\mathrm{H}_{0}$ : existem diferenças entre os parâmetros populacionais nas diferentes populações; $H_{1}$ : não existem diferenças destes padrões entre as populações. 


\section{MATERIAL E MÉTODOS}

\section{Área de estudo}

O litoral Norte do Estado de São Paulo é caracterizado pela grande proximidade da Serra do Mar com o Oceano Atlântico, formando uma costa extremamente recortada, com muitos costões rochosos, baias, enseadas e inúmeras praias de pequena extensão (Pires-Vanin, 1989) (Figura 1a, b). Estas características físicas proporcionam condições adequadas à vida de muitas espécies de crustáceos (Mantelatto \& Fransozo, 1999).

A Enseada de Ubatuba está localizada próxima ao centro do Município de Ubatuba. Possui uma área de aproximadamente $16 \mathrm{~km}^{2}$, com oito pequenas praias delimitadas por costões rochosos que avançam sobre o mar e recebe a descarga de quatro rios de pequeno porte que influenciam na salinidade e na quantidade de matéria orgânica do local (Mantelatto \& Fransozo, 1999), incluindo o rio Indaiá localizado na praia do Perequê-açu.

A praia do Perequê-açu $\left(23^{\circ} 25^{\prime} S, 45^{\circ} 03^{\prime} \mathrm{W}\right)$ está localizada na extremidade norte da Enseada de Ubatuba, sendo caracterizada como uma praia arenosa de estado morfodinâmico dissipativo (ver Schmiegelow, 2004 para revisão), de pouca inclinação, com ondas de pequena altura e areia de menor granulometria. O clima da região onde está localizada é tropical úmido, com estação chuvosa durante o verão (Castro-Filho et al., 1987). 


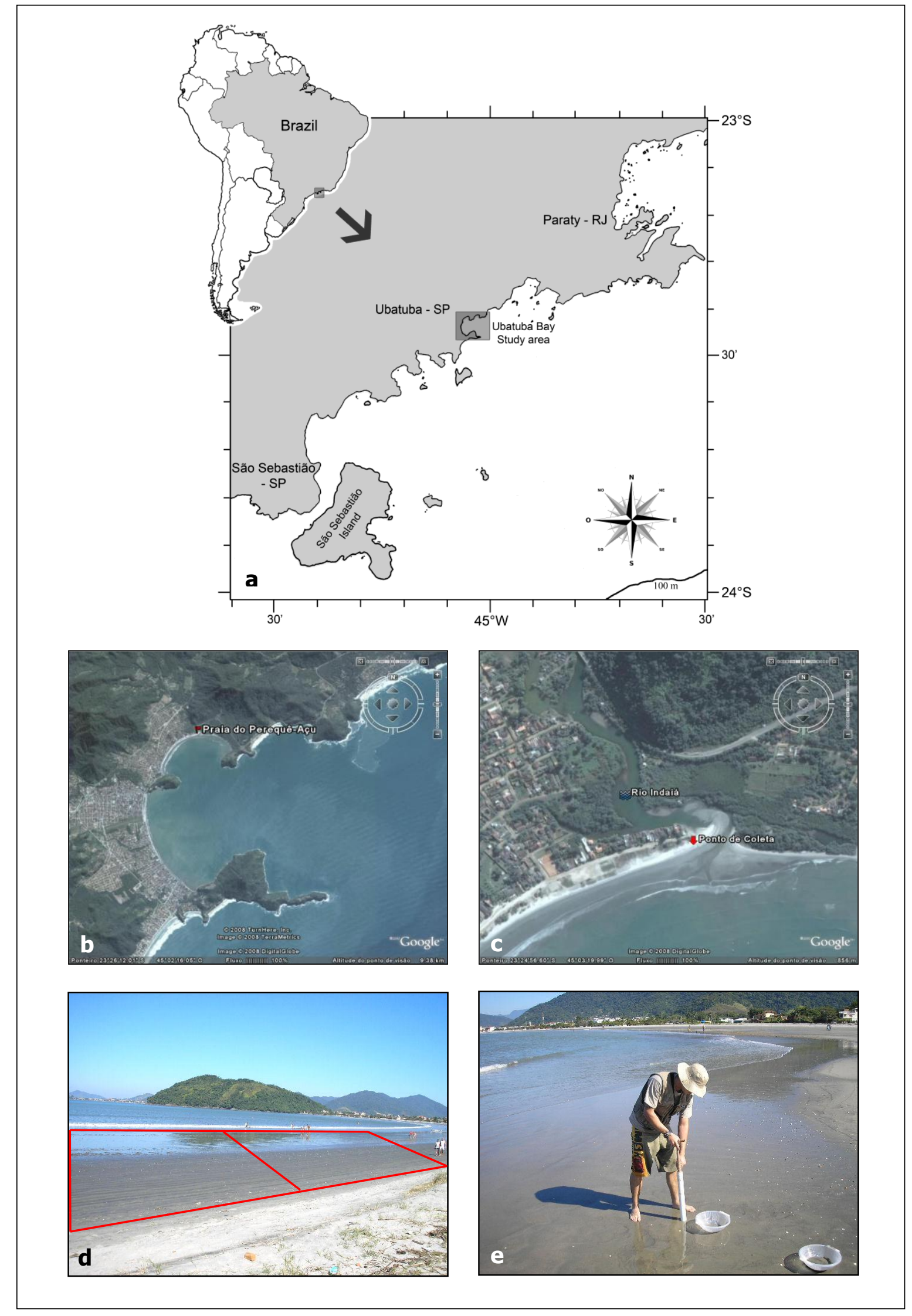

Figura 1. Localização do litoral norte do Estado de São Paulo, Brasil, em detalhe a Enseada de Ubatuba (a); imagem da Enseada de Ubatuba (b); imagem da praia do Perequê-açu (c); área de coleta fixa predeterminada (d); foto do método de coleta (e). 


\section{Coleta e processamento}

As coletas foram realizadas bimestralmente na região entremarés da praia do Perequê-açu, próximo à margem direita da barra do rio Indaiá, de setembro/2008 a julho/2009 (Figura 1c). Estas foram conduzidas durante as marés baixas diurnas (com base na Tábua de Marés do Porto de São Sebastião/SP, disponibilizada pela Diretoria de Hidrografia e Navegação da Marinha do Brasil), em dois dias consecutivos, em uma área fixa prédeterminada da praia com 100 m de comprimento e $30 \mathrm{~m}$ de largura (Figura 1d).

A área de coleta predeterminada se inicia a $46 \mathrm{~m}$ de um ponto fixo

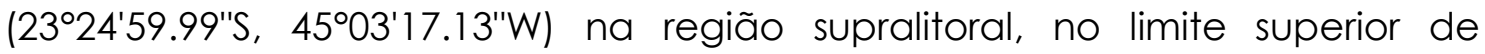
ocorrência de C. macrotelsonis, e se estende por 30 m até a linha d'água em maré de $0 \mathrm{~m}$. Os espécimes de C. macrotelsonis foram capturados em apenas 50 m do comprimento da área de amostragem (Figura 1d) e extraídos de suas galerias com duas bombas manuais de sucção (comprimento $\approx 1 \mathrm{~m}$ ) [metodologia estabelecida por Rodrigues (1966); e similar à descrita por Manning (1975)] (Figura 1e). Depois de extraídos de suas galerias, os animais foram colocados individualizados em sacos plásticos etiquetados e posteriormente congelados para análise em laboratório, local onde foram transferidos a frascos etiquetados e preservados em álcool etílico a $80 \%$.

Durante as coletas cada galeria foi bombeada até três vezes, no intuito de aumentar a eficiência da captura, uma vez que após isso as paredes das galerias colapsam devido à natureza do substrato. O rápido colapso não interfere na captura dos animais. Além disso, esse método elimina o risco de amostrar a mesma galeria mais que uma vez (Alves \& Pezzuto, 1998; Peiró \& Mantelatto, 2011). 
Os outros $50 \mathrm{~m}$ da área de amostragem preestabelecida foram utilizados para a estimativa da densidade. Para isso foi lançada aleatoriamente (108 vezes) duas unidades amostrais composta por dois quadrantes de $1 \mathrm{~m}^{2}$, para contagem das aberturas das galerias de $\mathrm{C}$. macrotelsonis. A densidade foi estimada pelo número médio de aberturas das tocas contadas por metro quadrado $\left(a b . \bullet \mathrm{m}^{-2}\right)$. Cada abertura foi considerada a galeria de um indivíduo distinto (Rodrigues \& Shimizu, 1997).

As galerias de C. macrotelsonis possuem uma única abertura para a superfície da praia, com aspecto variável e diâmetro de aproximadamente 5 $\mathrm{mm}$. Ao orifício de abertura segue-se um estreito túnel perpendicular à superfície, que se aprofunda na areia sem variação de diâmetro por 20 a 40 cm (Rodrigues \& Shimizu, 1997), local onde ficam "alojados", entre outros grupos, caranguejos simbiontes da família Pinnotheridae (Peiró \& Mantelatto, 2011). A partir deste ponto o diâmetro do túnel se alarga, muda de direção e em seguida se aprofunda novamente. O comprimento deste último trecho, assim como seu diâmetro, é proporcional ao tamanho do indivíduo habitante, que pode chegar até aproximadamente 1,5 $\mathrm{m}$ de profundidade e entre $10 \mathrm{a}$ 30 mm de diâmetro (Rodrigues \& Shimizu, 1997).

O perfil topográfico da praia foi mensurado em cada coleta por meio de um transecto perpendicular à linha d'água, do ponto fixo (citado anteriormente) no supralitoral até a linha d'água em maré de 0,0 $\mathrm{m}$, pelo método de mangueira de nível. Os dados foram tomados a cada $8 \mathrm{~m}$ ao longo do transecto (totalizando 10 pontos de aferições), e foram utilizados para quantificar variações topográficas bimestrais causadas pelos processos de erosão e deposição do sedimento na praia. 
A temperatura e a salinidade da água da praia foram aferidas (água superficial de um ponto com aproximadamente $1 \mathrm{~m}$ de profundidade) antes do início de cada coleta com um termômetro de mercúrio (escala: -10 $200^{\circ} \mathrm{C}$, Incoterm ${ }^{\circledR}$ ) e com um refratômetro óptico de mão (salinidade: 0 100\%o, Atago $\left.^{\circledR}\right)$, respectivamente.

Em laboratório, o tamanho de C. macrotelsonis, que é determinado pelo comprimento da área oval da carapaça (CO) (Figura 2) foi mensurado com um paquímetro de precisão $0,05 \mathrm{~mm}\left(\right.$ Zass $\left.^{\circledR}\right)$.

Os calianassídeos foram classificados em machos e fêmeas de acordo com a localização dos gonóporos; sendo que nos machos estão localizados nas coxas do quinto par de pereiópodos e nas fêmeas na coxa do terceiro par, e também pelo dimorfismo do maior quelípodo dos machos, que possuem um dente proximal na face ventral do mero. As fêmeas ovígeras foram classificadas pela presença da massa de ovos aderida aos pleópodos. Foi considerado o tamanho médio de maturidade sexual em aproximadamente 11,85 mm CO [baseado na razão entre a largura do abdômen (LA no terceiro seguimento abdominal) e o comprimento da área oval da carapaça pelo comprimento da área oval da carapaça; vide Capítulo II]. Isso, tanto para machos quanto para fêmeas, devido a inexistência de diferenças estatísticas significativas nos tamanhos médios, assim como a pouca diferença entre os tamanhos máximos entre eles (ver Resultados). 


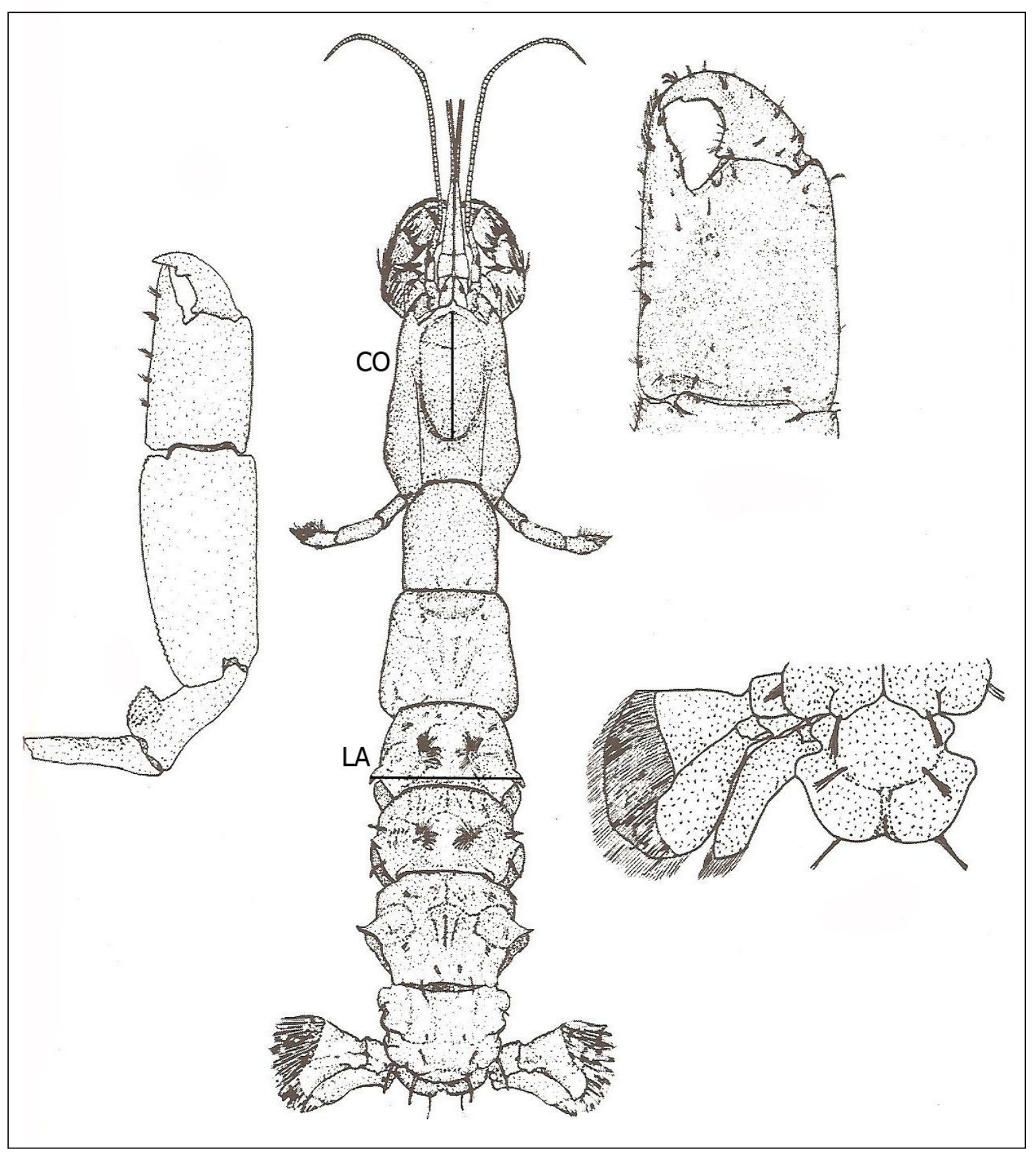

Figura 2. Callichirus macrotelsonis $(103,0 \mathrm{~mm}$ de comprimento total), modificado de Melo (1999), como C. major. Comprimento da área oval da carapaça (CO), largura máxima do abdômen (LA) (terceiro segmento). 


\section{Dinâmica populacional}

Para quantificar o grau de relação linear entre os fatores ambientais (temperatura d'água e salinidade) e a abundância dos indivíduos em cada bimestre, foi utilizado o coeficiente de correlação de Pearson. Esse coeficiente é um número adimensional e não tem unidade de medida $(-1 \leq r \leq 1)$. Valores $r$ $=1$ e $r=-1$ ocorrem quando há uma exata relação linear entre as variáveis. Quando r = 0 não há relação linear, e as variáveis não são correlacionadas.

Para avaliar a normalidade da distribuição da população de acordo com o tamanho dos indivíduos, foi utilizado o Teste de Normalidade (Kolmogorov-Smirnov). O número de classes de tamanho foi determinado com o cálculo de Sturges (1926) (apud Beer \& Swanepoel, 1999): $k=1+\log _{2}$ n, onde "k" é o número de classes e "n" é o tamanho da amostra.

Diferenças do padrão esperado 1:1 na razão sexual foram checadas pelo teste $\chi^{2}$ para o total de indivíduos coletados, para cada coleta e para cada classe de tamanho (Wenner, 1972). A proporção sexual de uma população é estimada pela comparação entre o número de machos e de fêmeas de uma determinada amostra. De acordo com a teoria de Fisher (1930), a seleção natural favorece uma proporção macho/fêmea de 1:1 nos descendentes de espécies animais, porém desvios desta proporção são muito comuns entre os crustáceos marinhos. Wenner (1972) descreveu alguns classificações para a razão sexual de crustáceos: Padrão: onde não há diferenças significativas entre a proporção macho/fêmea nas primeiras classes de tamanho, favorecendo os machos nas classes finais; Reverso: onde a ausência de machos ou de fêmeas nas menores classes de tamanho resulta em um gráfico com curva sigmoide e pode levar à conclusão sobre reversão sexual; Intermediário: onde o ingresso de animais jovens na população não é 
igualmente representado por machos e fêmeas, sendo o padrão que mais viola a teoria de Fisher (1930); Anômalo: onde a proporção entre machos e fêmeas tende a se diferenciar de acordo com o aumento do tamanho do animal. Além destas, foram propostas as classificações "Padrão Predominante", onde há a predominância de um dos sextos que quase todas as classes de tamanho (Terossi \& Mantelatto, 2010); e a "Padrão Próximo" a qual difere do "Padrão" de Wernner (1972) por apresentar diferenças significativas pontuadas ao longo das classes de tamanho em favor tanto de machos quanto das fêmeas (Peiró \& Mantelatto, 2011).

As diferenças entre os tamanhos médios de machos e de fêmeas de C. macrotelsonis foram testadas pelo teste $t$ de Student.

A determinação do período reprodutivo e o indício de períodos de recrutamento foram identificados pela análise bimestral da proporção de fêmeas ovígeras em relação ao total de fêmeas (Pinheiro \& Fransozo, 2002), e pela presença de indivíduos com as menores classes de tamanho nas amostras, respectivamente.

As análises estatísticas foram feitas com o programa Pas $\dagger^{\circledR}$ e Statistica ${ }^{\circledR}$ 8.0, segundo procedimentos de Zar (1996) adotando nível de significância de $P<0,05$. 


\section{RESULTADOS}

\section{Fatores ambientais}

A temperatura da água da praia variou de $23^{\circ} \mathrm{C}$ (novembro/2008 e julho/2009) a $28^{\circ} \mathrm{C}$ (março/2009) durante o período de estudo, com média e desvio padrão de $24,7 \pm 2,0^{\circ} \mathrm{C}$, respectivamente. Houve uma clara oscilação sazonal, com temperaturas maiores nos meses de verão e inferiores nos de inverno (Figura 3).

A salinidade apresentou uma grande amplitude durante o período de estudo, com mínima de 16\%。 (março/2009), provavelmente influenciada pela água doce do rio Indaiá, e máxima de 32\%o (setembro/2008) (27,2 \pm 5,7\%o). Não foi constatado nenhum padrão relacionado à sazonalidade.

A temperatura e a salinidade não foram estatisticamente correlacionadas entre si $(r=-0,46 ; P=0,301)$. Também não foi constatada nenhuma correlação estatística significativa entre a temperatura ( $r=-0,237$; $P$ $=0,608)$ e a salinidade $(r=-0,125 ; P=0,789)$ com o número total de indivíduos, assim como para machos, total de fêmeas, fêmeas ovígeras e juvenis, individualmente $(P>0,05)$. 


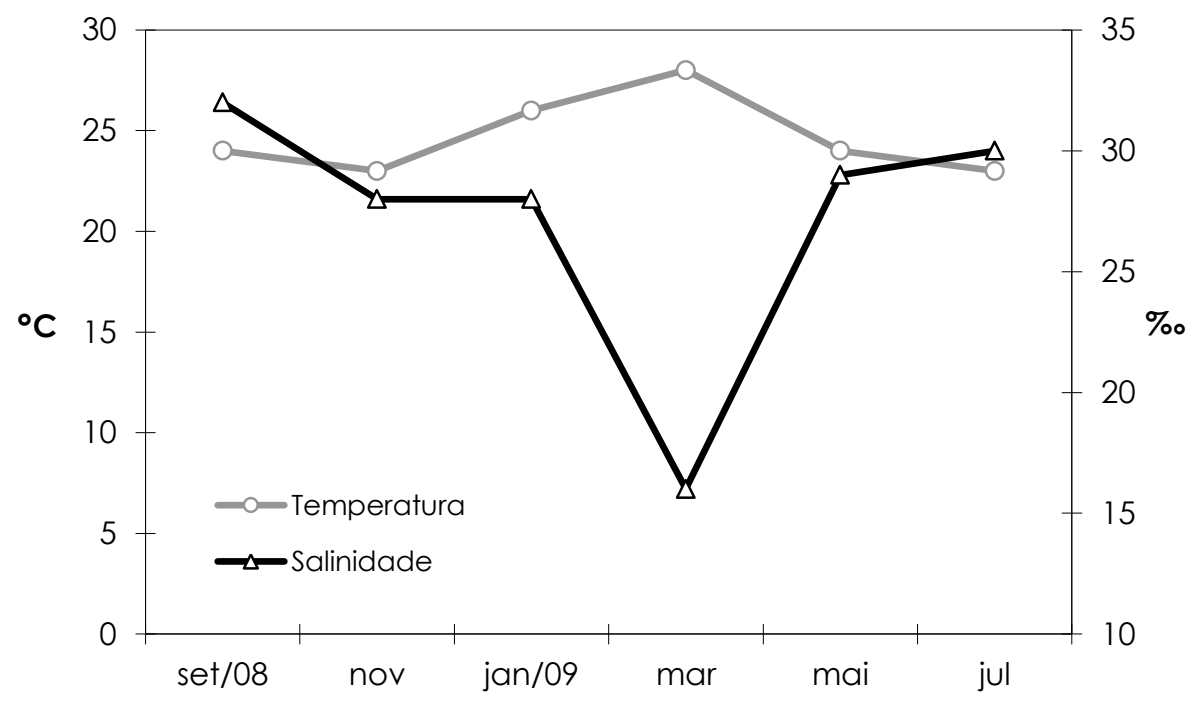

Figura 3. Variação bimestral da temperatura da água $\left({ }^{\circ} \mathrm{C}\right)$ e da salinidade (\%). Valores obtidos antes de cada coleta na praia do Perequê-açu, Ubatuba/SP, de setembro/2008 a julho/2009.

\section{Perfil topográfico da praia}

As variações temporais no perfil da praia mostraram um claro processo erosional ocorrendo entre setembro/2008 e novembro/2008 (Figura 4). Após esse período, foi observado um processo de deposição refletido em janeiro/2009, seguido por dois bimestres de erosões subsequentes (março/2009 e maio/2009). Em julho/2009 foi observado um novo processo de deposição de areia na praia. 


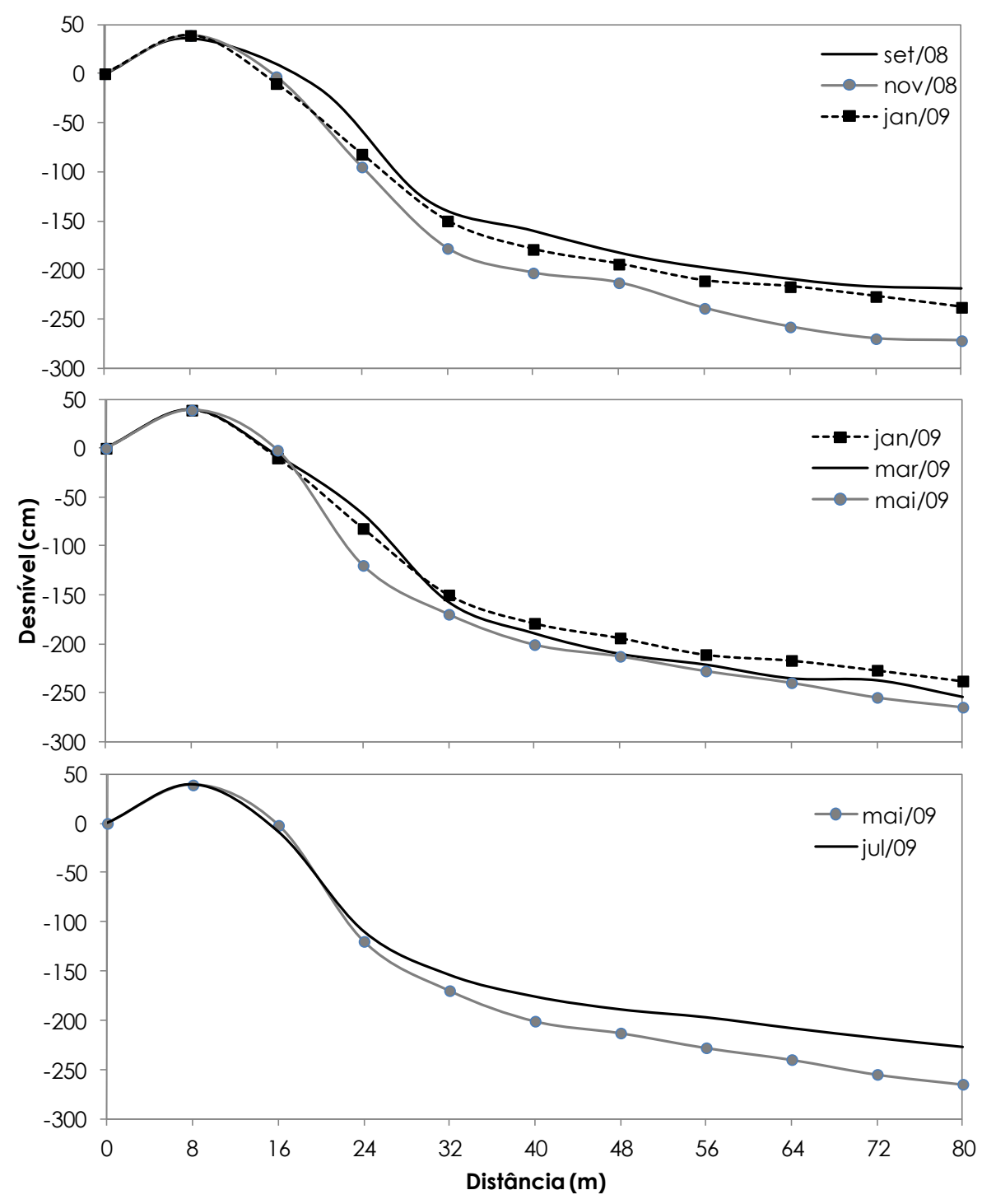

Figura 4. Perfil topográfico da praia do Perequê-açu, Ubatuba/SP em uma variação temporal durante o período de estudo, de setembro/2008 a julho/2009. 


\section{Dinâmica populacional}

Foram coletados 164 exemplares de C. macrotelsonis: 67 machos (40,9\%), 94 fêmeas $(57,3 \%)$, sendo 24 destas ovígeras $(14,6 \%)$, e 3 indivíduos impossibilitados de serem identificados por estarem danificados (1,8\%). A população de C. macrotelsonis na praia do Perequê-açu variou quanto ao número de indivíduos coletados bimestralmente, sendo novembro/2008 (n = 49) e março/2009 ( $\mathrm{n}=7$ ) os meses de maior e menor captura destes, respectivamente (Tabela 1).

Tabela 1. Callichirus macrotelsonis coletados bimestralmente na praia do Perequê-açu, Ubatuba/SP, de setembro/2008 a julho/2009. Porcentagem de fêmeas ovígeras em relação ao total de fêmeas (\%). Indivíduos não identificados (NI). Razão entre machos e fêmeas (M:F). Densidade de indivíduos por metro quadrado $\left(a b . \bullet \mathrm{m}^{-2}\right)$ e desvio padrão. Porcentagem de eficiência de captura (\%).

\begin{tabular}{|c|c|c|c|c|c|c|c|c|c|c|}
\hline \multirow{2}{*}{$\begin{array}{l}\text { Datas de } \\
\text { coleta }\end{array}$} & \multicolumn{6}{|c|}{$\mathrm{N}^{\circ}$. de indivíduos } & \multirow{2}{*}{$\begin{array}{c}\text { Razão } \\
\text { M:F }\end{array}$} & \multicolumn{2}{|c|}{ Densidade } & \multirow{2}{*}{$\begin{array}{c}\% \\
\text { Captura }\end{array}$} \\
\hline & Total & Machos & Fêmeas total & Ovígeras & (\%) & $\mathrm{NI}$ & & $a b . \cdot m^{-2}$ & desv. pad. & \\
\hline Set/08 & 21 & 11 & 9 & 2 & 22,2 & 1 & 1,22 & 0,098 & 0,299 & 13,9 \\
\hline Novembro & 49 & 21 & 26 & 11 & 42,3 & 2 & 0,81 & 0,222 & 0,439 & 43,5 \\
\hline Jan/09 & 24 & 11 & 13 & 5 & 38,5 & 0 & 0,85 & 0,042 & 0,201 & 30,4 \\
\hline Março & 7 & 4 & 3 & 3 & 100,0 & 0 & 1,33 & 0,241 & 0,471 & 11,5 \\
\hline Maio & 16 & 2 & 14 & 0 & 0,0 & 0 & 0,14 & 0,056 & 0,232 & 41,7 \\
\hline Julho & 47 & 18 & 29 & 4 & 13,8 & 0 & 0,62 & 0,398 & 0,773 & 18,8 \\
\hline Total & 164 & 67 & 94 & 25 & 26,6 & 3 & 0,71 & 0,202 & 0,494 & 26,6 \\
\hline
\end{tabular}

O comprimento da área oval da carapaça variou entre 6,55 a 15,65 mm (10,32 $\pm 2,25$ mm; média \pm desvio padrão) nos machos; e entre 5,95 a 15,05 $\mathrm{mm}(10,78 \pm 2,50)$ nas fêmeas. Não foram constatadas diferenças estatisticamente significativas entre o comprimento da área oval da carapaça entre os sexos (teste $t: 1,19 ; P=0,2377$ ). Indicando ausência de dimorfismo sexual relacionada a esta dimensão. A população apresentou uma distribuição bimodal em classes de tamanho para o total de indivíduos ( $\mathrm{K}-\mathrm{S}$ d = 
$0,122 ; P<0,05)$. Os picos (modas) ocorreram nas classes entre $9,1-\mid 10,4 \mathrm{~mm}$ (CO), representados quase que igualmente por machos e fêmeas, e entre 13,0-14,3 mm (CO), principalmente representados pelas fêmeas ovígeras (Figura 5).

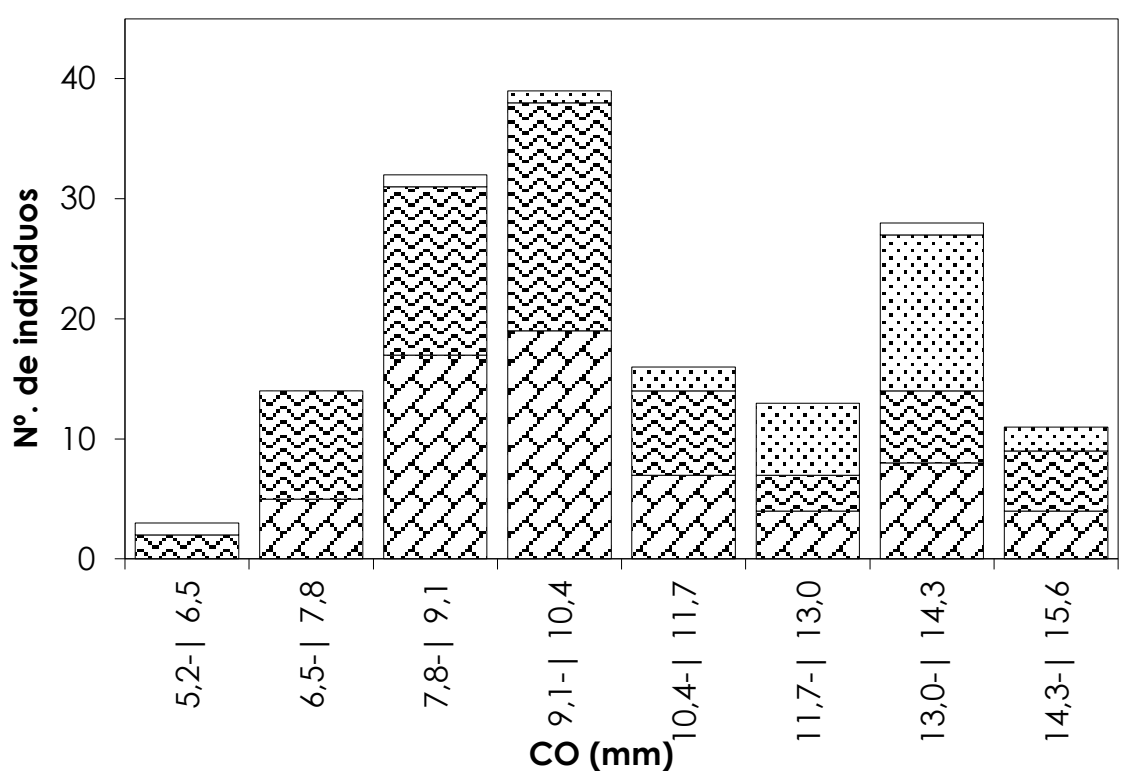

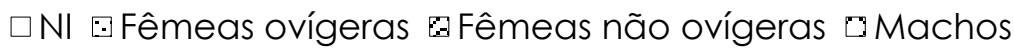

Figura 5. Callichirus macrotelsonis, distribuição de frequência de tamanhos dos indivíduos coletados na praia do Perequê-açu, Ubatuba/SP, de setembro/2008 a julho/2009. Indivíduos não identificados (NI). Comprimento da área oval da carapaça em $\mathrm{mm}$ [CO $(\mathrm{mm})]$.

A contribuição relativa de machos, fêmeas não ovígeras e fêmeas ovígeras variou durante todo o período amostral (Figura 6), entretanto a razão sexual não foi diferente de 1:1 nos bimestres coletados $(P>0.05)$, com exceção de maio/2009 (Tabela 1). A proporção sexual total desta população foi de 0,71 machos para 1 fêmea, desviando significativamente da razão esperada de $1: 1 \quad\left(\chi^{2}=4,08 ; P>0,05\right)$. Foi identificado que na maioria das classes de tamanho as proporções sexuais não foram significativamente diferentes de 1:1 ( $p>0,05)$, com exceção da classe 13,0-|14,3 mm. Em todas 
as classes de tamanho, com exceção da classe 7,8-|9,1, a proporção sexual esteve em favor das fêmeas (Figura 7).

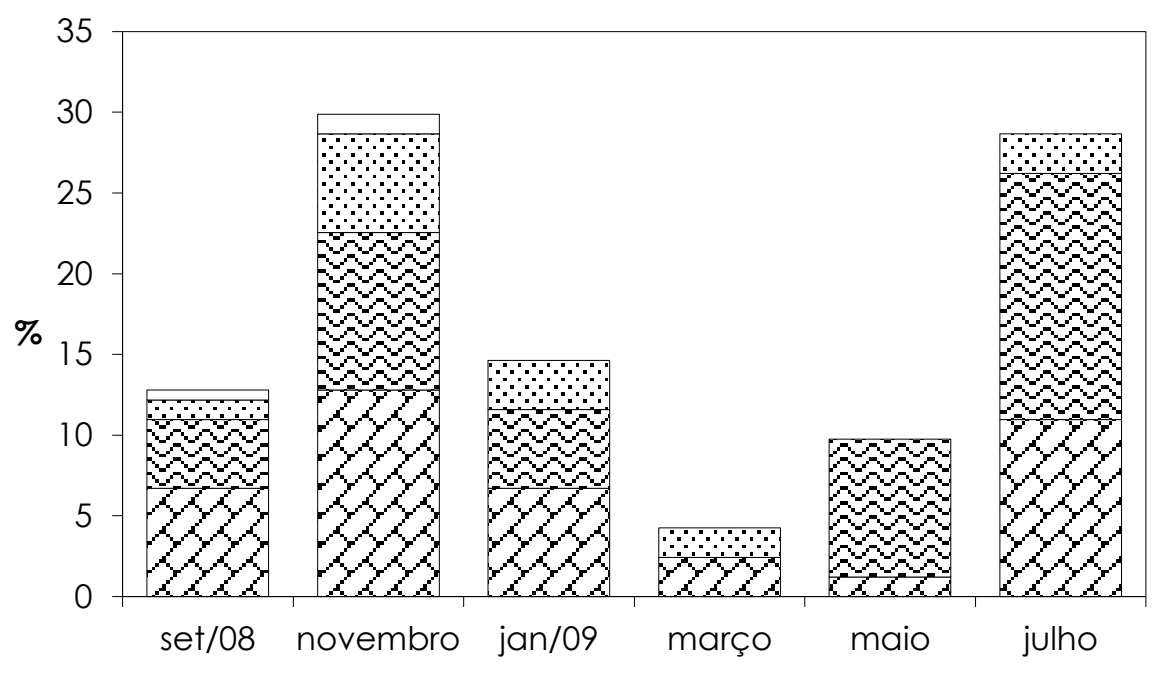

$\square$ NI : Fêmeas ovígeras a Fêmeas não ovígeras $₫$ Machos

Figura 6. Callichirus macrotelsonis, frequência bimestral de machos, fêmeas não ovígeras, fêmeas ovígeras e indivíduos não identificados (NI) da praia do Perequê-açu, Ubatuba/SP, de setembro/2008 a julho/2009.

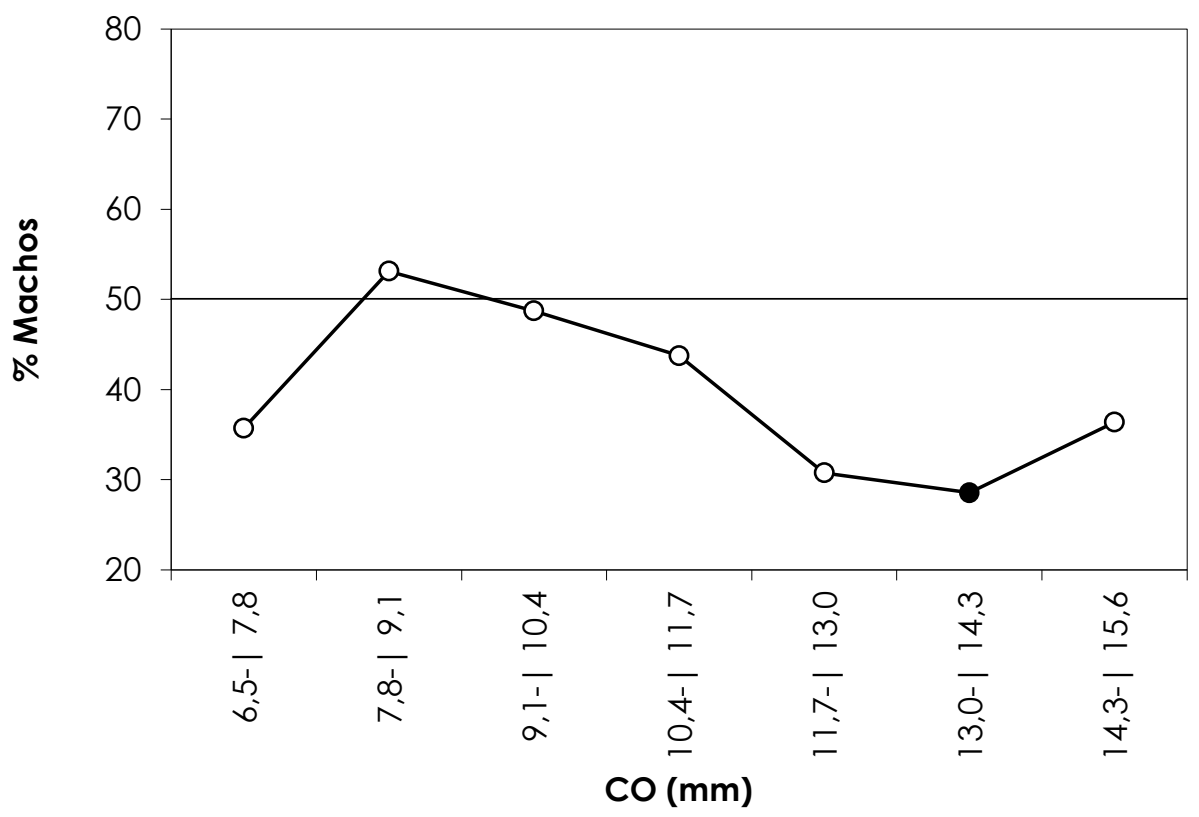

Figura 7. Callichirus macrotelsonis, porcentagem de machos em relação ao total de machos e fêmeas por classe de tamanho, coletados na praia do Perequê-açu, Ubatuba/SP, de setembro/2008 a julho/2009. Comprimento da área oval da carapaça (CO). Círculo preenchido: classe de tamanho com razão sexual significativamente diferente de 1:1. 
A densidade populacional média foi de 0,202 \pm 0,494 ab. $\bullet \mathrm{m}^{-2}$ (variando de 0 a 4 ab. $\bullet \mathrm{m}^{-2} ; \mathrm{n}=108$ quadrantes amostrados). A menor densidade média foi registrada em janeiro/2009 $\left(0,028 \pm 0,299 \mathrm{ab} \cdot \bullet \mathrm{m}^{-2}\right)$ e a maior em julho/2009 $\left(0,398 \pm 0,773 \mathrm{ab} \cdot \mathrm{m}^{-2}\right)$, com uma nítida variação durante todo o período amostral (Figura 8).

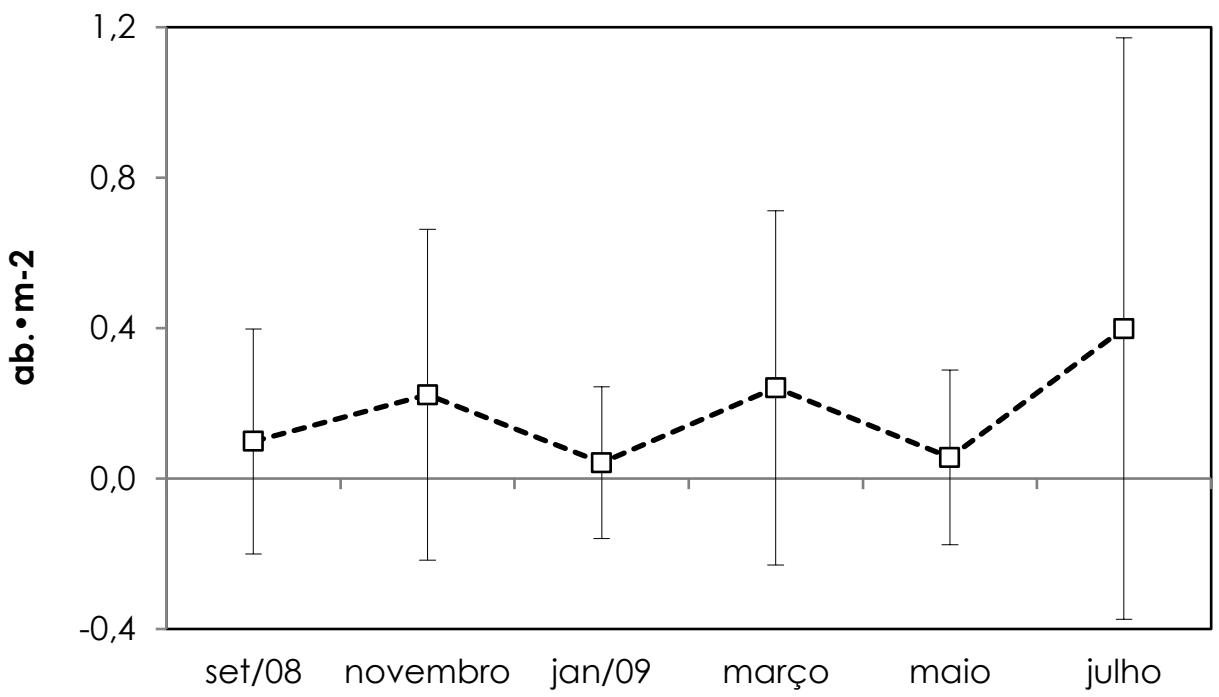

Figura 8. Callichirus macrotelsonis, variação bimestral na densidade média na praia do Perequê-açu, Ubatuba/SP, de setembro/2008 a julho/2009. Número de aberturas/indivíduos por metro quadrado (ab.• $\mathrm{m}^{-2}$ ).

A eficiência de captura de C. macrotelsonis na Praia do Perequê-açu foi de $26,6 \%$. Entretanto, com uma evidente variação ao longo do período de amostragem, com eficiência mínima de 11,5\% em março/2009, valor que acompanha um decréscimo iniciado no bimestre anterior $(30,4 \%)$, e máxima de $43,5 \%$ em novembro/2008 (Figura 9). 


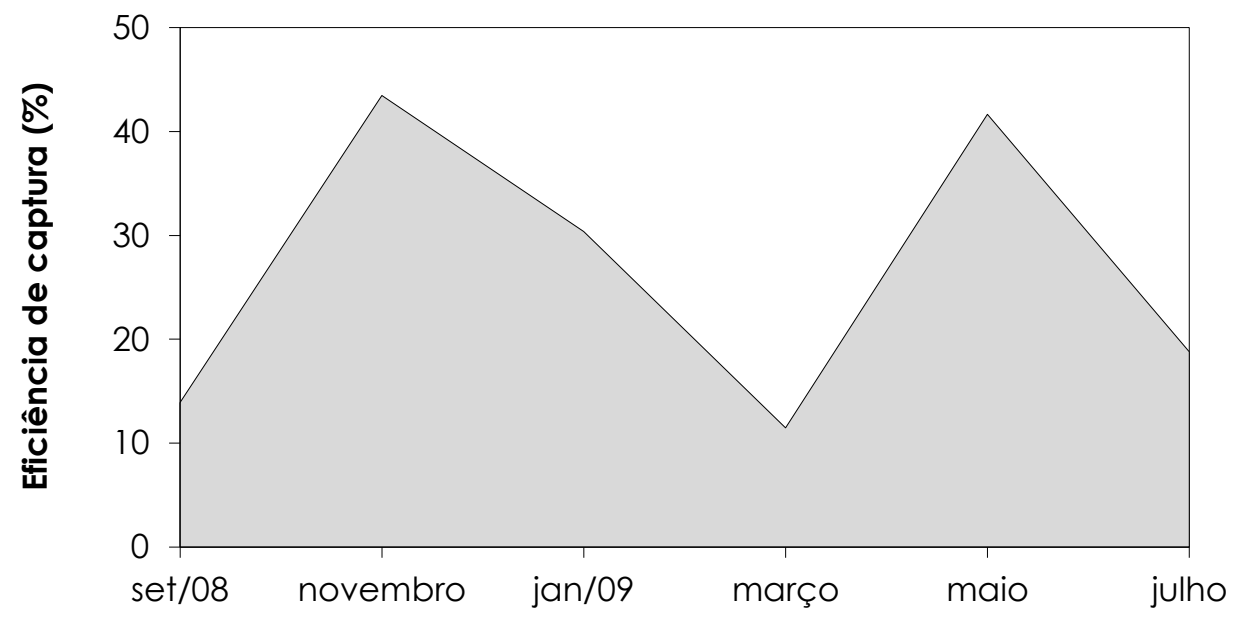

Figura 9. Callichirus macrotelsonis, variação bimestral na eficiência de captura de indivíduos na praia do Perequê-açu, Ubatuba/SP, de setembro/2008 a julho/2009.

A porcentagem de fêmeas ovígeras em relação ao total de fêmeas foi de 26,6\% (25 indivíduos), variando de 13,8 (jul/2009) a 100\% (mar/2009; $n=3$ ) entre os bimestres amostrados (Tabela 1 e Figura 6). As fêmeas ovígeras estiveram presentes em quase todos os bimestres, com exceção de maio/2009. Estiveram em número expressivo em novembro/2008 n =11 (em um total de 26 fêmeas, 42,3\%). Devido a presença de fêmeas ovígeras durante quase todo o ano e com o pico sazonal de novembro/2008, o período reprodutivo foi classificado como sazonal contínuo. Foi identificado que os indivíduos pertencentes à menor classe de tamanho coletada estiveram presentes somente em maio/2009, além da presença expressiva de indivíduos da classe de tamanho subsequente neste mesmo mês (Figura 10). Esse fato pode estar relacionado ao pico de ovígeras em novembro/2008. Não foram encontrados indivíduos com tamanhos inferiores a 5,95 $\mathrm{mm} \mathrm{CO}$, sendo assim, impede-se de inferir diretamente sobre o recrutamento da espécie, já que os 
indivíduos recém assentados e pertencentes aos (reais) menores tamanhos não se encontraram na área de amostragem.
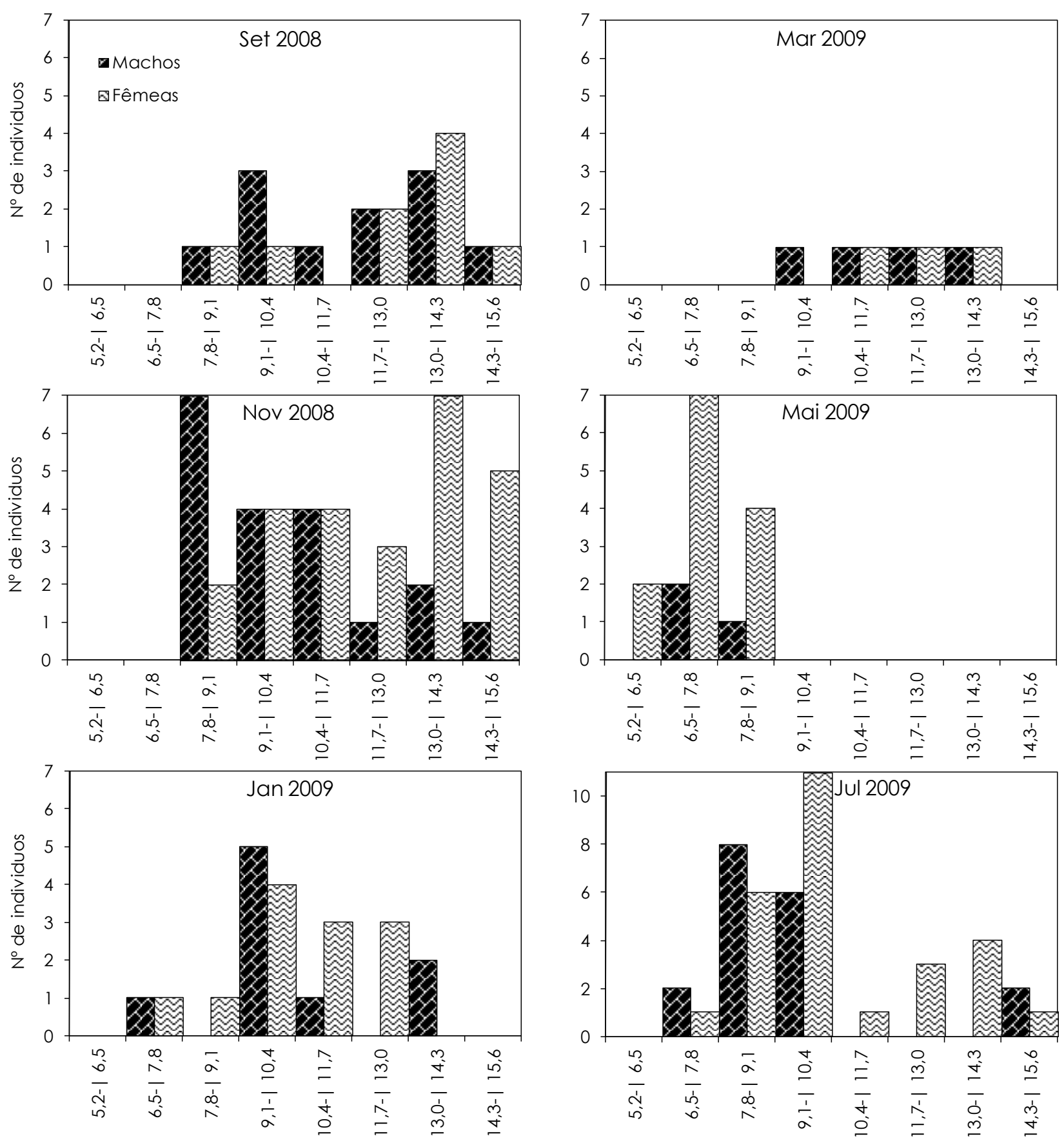

Figura 10. Callichirus macrotelsonis, distribuição de indivíduos em classes de tamanho (comprimento da área oval da carapaça) na praia do Perequêaçu, Ubatuba/SP, de setembro/2008 a julho/2009. 


\section{Discussão}

\section{Fatores ambientais}

A temperatura da água de onde crustáceos estão instalados pode agir como um regulador metabólico e hormonal, desencadeando os processos de ecdise, cópula e desenvolvimento gonadal (Sastry, 1983). Entretanto neste estudo na praia do Perequê-açu, C. macrotelsonis não apresentou correlação com os fatores abióticos analisados. Nem mesmo as fêmeas ovígeras, que usualmente estão mais sujeitas a ação direta destes fatores em função da maturação dos ovos (Sastry, 1983).

A ausência de correlação pode estar relacionada ao fato da aferência dos dados abióticos terem sido realizadas de forma pontual, e podem não refletir os valores que melhor representam os bimestres amostrados. Além disso, regiões tropicais e subtropicais apresentam variação sazonal menos profunda dos fatores ambientais, demonstrando poucas modificações destes parâmetros durante o ano, sendo às vezes impossível identificar de forma bem definida as quatro estações do ano (Ayres-Peres \& Mantelatto, 2008), fator que também poderia corroborar a ausência de correlação dos crustáceos aqui estudados com a temperatura e a salinidade.

\section{Perfil topográfico da praia}

Houve uma clara variação nos processos de deposição e de erosão na praia durante o período estudado, com uma alternância, quase que constante, de um bimestre sofrendo processos erosivos e no bimestre subsequente deposição. A zona de ocorrência de C. macrotelsonis se inicia em, aproximadamente, 46 metros do ponto fixo estabelecido neste estudo, até a zona rasa da região submareal da praia. 
Em uma amostragem paralela àquelas realizadas neste estudo (em uma condição distinta do usual, de maré negativa associada ao vento a favor da maré vazante) foi possível observar um elevado número de galerias de $C$. macrotelsonis na região infralitoral (obs. pessoal). $\bigcirc$ valor de densidade $(3,94 \pm$ 2,43 ab. $\cdot \mathrm{m}^{-2}$ ) foi muito superior àqueles encontrados na região mediolitoral que normalmente é exposta durante as marés baixas.

A elevada extração da espécie nesta praia, feita pela comunidade de pescadores locais, pode ter causado a diminuição da ocorrência de C. macrotelsonis na região mediolitoral, consequentemente, os indivíduos ocupam predominantemente a zona infralitoral que é mais difícil de ser acessada pelos extratores. Na zona infralitoral, também foram coletados indivíduos com menores tamanhos (obs. pessoal), e onde, provavelmente, estejam os indivíduos recém-assentados, pertencentes às (reais) menores classes de tamanho. Isso é assumido, já que os sinais químicos provenientes de indivíduos adultos "direcionam" os indivíduos que estão no final do estágio larval, em transição para a fase de assentamento (Strasser \& Felder, 1998; 1999). Outro fator que dificulta a captura de indivíduos juvenis é o fato deles não serem facilmente detectáveis na areia pela presença da abertura de suas tocas, isso estaria relacionado a sua menor atividade quando comparada a dos adultos (Rodrigues \& Shimizu, 1997).

\section{Dinâmica populacional}

A dinâmica de C. macrotelsonis varia consideravelmente dentre as diferentes populações estabelecidas na costa brasileira (Tabela 2). Esse perfil pode ser, provavelmente, influenciado pelas diferenças na temperatura da água de onde as populações estão estabelecidas (e.g., Baver 1992; Lardies \& 
Castilla 2001; Terossi et al., 2010; Wehrtmann et al., 2012). Apesar de não terem sido detectadas correlações entre os fatores abióticos e os callianassídeos deste estudo, não quer dizer que esses fatores não tenham a devida influencia sobre os mesmos. Provimento de matéria orgânica da praia onde as populações estão instaladas (proveniente de rios, zonas de ressurgência, despejo de esgoto doméstico e etc.), características específicas do substrato, além de características intrínsecas das populações também são fatores que influenciam este grupo de crustáceos. As características intrínsecas das populações possuem particularidades, como por exemplo, o tamanho de seus indivíduos ao longo das distintas áreas de ocorrência; o que pode ser suposto como sendo adaptações (ao longo de várias gerações) às condições dos locais que habitam (Tabela 2).

Tabela 2. Parâmetros populacionais de algumas populações de Callichirus macrotelsonis (como Callichirus major) reportadas em diferentes latitudes no Brasil. CO mm: comprimento da área oval da carapaça em milímetros. ab. $\cdot \mathrm{m}^{-2}$ : número de aberturas por metro quadrado.

\begin{tabular}{|c|c|c|c|c|c|}
\hline $\begin{array}{l}\text { Estado } \\
\text { (Latitude) }\end{array}$ & $\begin{array}{l}\text { Densidade ab. } \cdot \mathbf{m}^{-2} \\
\pm \text { desv. pad. }\end{array}$ & $\begin{array}{l}\text { Tamanho de } \\
\text { fêmeas ovígeras } \\
\text { (mín-máx; CO mm) }\end{array}$ & $\begin{array}{l}\text { Período } \\
\text { Reprodutivo }\end{array}$ & $\begin{array}{c}\text { Temperatura } \\
\text { da água } \\
\left({ }^{\circ} \mathrm{C}\right)\end{array}$ & Referencias \\
\hline $\begin{array}{l}\text { Pernambuco } \\
\left(8^{\circ} 11^{\prime} S\right)\end{array}$ & - & $7.2-12.62$ & $\begin{array}{l}\text { sazonal contínuo } \\
\text { (ago-set lacuna) } \\
\text { (dez-maio pico) }\end{array}$ & $26-31$ & $\begin{array}{l}\text { Botter-Carvalho } \\
\text { et al. (2007) }\end{array}$ \\
\hline $\begin{array}{l}\text { Rio de Janeiro } \\
\left(22^{\circ} 46^{\prime} S\right)\end{array}$ & $12,97 \pm 8,5$ & - & $\begin{array}{l}\text { sazonal } \\
\text { set-mar } \\
\text { (nov-jan pico) }\end{array}$ & - & $\begin{array}{l}\text { Simão et al. } \\
\text { (2006); Ramos } \\
\text { et al. (2007) }\end{array}$ \\
\hline $\begin{array}{l}\text { Rio de Janeiro } \\
\left(23^{\circ} 04^{\prime} S\right)\end{array}$ & - & $11.91-16.18$ & $\begin{array}{l}\text { sazonal } \\
\text { ago-fev } \\
\text { (dez-jan pico) }\end{array}$ & - & $\begin{array}{l}\text { Sendim et al. } \\
\text { (2007) }\end{array}$ \\
\hline $\begin{array}{l}\text { São Paulo } \\
\left(23^{\circ} 24^{\prime} S\right)\end{array}$ & $0,202 \pm 0,494$ & $10.3-15.0$ & $\begin{array}{l}\text { sazonal contínuo } \\
\text { (maio lacuna) } \\
\text { (nov-jan pico) }\end{array}$ & $23-28$ & Presente estudo \\
\hline $\begin{array}{l}\text { São Paulo } \\
\left(23^{\circ} 49^{\prime} S\right)\end{array}$ & 2-6,1 min.-máx. & $10.3-15 \sim$ & $\begin{array}{l}\text { sazonal } \\
\text { ago-dez }\end{array}$ & $20-27$ & $\begin{array}{l}\text { Shimizu (1997); } \\
\text { Shimizu \& Rosso } \\
\text { (2000) }\end{array}$ \\
\hline $\begin{array}{l}\text { São Paulo } \\
\left(23^{\circ} 58^{\prime} S\right)\end{array}$ & - & - & $\begin{array}{l}\text { sazonal contínuo } \\
\text { (dez-maio pico) }\end{array}$ & - & $\begin{array}{l}\text { Rodrigues \& } \\
\text { Shimizu (1997) }\end{array}$ \\
\hline $\begin{array}{l}\text { Paraná } \\
\left(25^{\circ} 55^{\prime} S\right)\end{array}$ & $\begin{array}{l}\text { 4,48 antes verão } \\
5,34 \text { após verão }\end{array}$ & $8,5-\mathrm{na}$ & nov-jan & $15-29$ & $\begin{array}{l}\text { Souza et al. } \\
\text { (1998); Souza \& } \\
\text { Borzone (2003) }\end{array}$ \\
\hline
\end{tabular}


O número de indivíduos coletados bimestralmente na população de C. macrotelsonis na praia do Perequê-açu variou consideravelmente, sendo que o menor valor de indivíduos coletados (março/2009, $\mathrm{n}=7$ ) pode estar relacionado à elevada captura por pescadores durante os meses anteriores (período de férias de verão) (Peiró \& Mantelatto, 2011) (Tabela 1). O maior número de indivíduos coletados foi em novembro/2008 (n = 49) (justamente 3-4 meses após o inverno e anterior ao período de elevada extração no verão), a presença de fêmeas ovígeras também foi evidentemente mais pronunciada neste mês ( $n=11$, correspondendo a $42,3 \%$ das fêmeas coletadas no período). A elevada abundância em novembro, associada ao pequeno número coletado após o verão, nos faz perguntar se a população, por meio de processos adaptativos, estaria estabelecendo um equilíbrio entre a captura e a disponibilidade de indivíduos neste período específico. Entretanto, estudos a longo prazo são necessários para conclusões mais contundentes.

A ausência de diferenças estatisticamente significativas entre tamanhos de machos e de fêmeas pode indicar que ambos os sexos atingem a maturidade sexual funcional em tamanhos aproximados, o que indica também a ausência de dimorfismo relacionado dimensão CO (como relatado no Capítulo II, Figura 4). Machos e fêmeas de C. macrotelsonis atingem a maturidade morfológica em aproximadamente $11,85 \mathrm{~mm} \mathrm{CO}$ na praia do Perequê-açu. Ainda, é possível identificar a grande diferença no tamanho da maturidade sexual funcional das fêmeas de C. macrotelsonis ao longo de sua área de distribuição, isso por meio da comparação do tamanho mínimo das fêmeas ovígeras (Tabela 2).

A bimodalidade na distribuição de indivíduos em classes de tamanho pode indicar picos de recrutamento (o que foi identificado indiretamente 
neste estudo), ou então picos na classe de tamanho na qual os indivíduos param de crescer (e. g. Peiró \& Mantelatto, 2011). Entretanto, neste estudo, o padrão bimodal vai contra as características preditas para o padrão de normalidade na distribuição (que geralmente reflete um recrutamento contínuo e uma constante taxa de mortalidade) (Díaz \& Conde, 1989). Mesmo que neste caso não esteja evidente o recrutamento por meio da identificação de indivíduos das (reais) menores classes de tamanho, o período reprodutivo pode ser classificado como sazonal contínuo (e.g. Pinheiro \& Terceiro, 2000), pela presença constante de fêmeas ovígeras, com um pico de abundância destas em um período específico (novembro/2008).

A razão sexual total diferiu significativamente do padrão de Fischer (1930) que presume que "a seleção natural favorece a mesma proporção no número de indivíduos de ambos os sexos". Quando existem variações na proporção de machos e de fêmeas, elas podem ser atribuídas às diferenças no ciclo de vida, migração, mortalidade e crescimento diferenciados entre os sexos; assim como devido a fatores biogeográficos e fatores intraespecíficos (Wenner et al., 1974). Além disso, atribuída à distribuição no habitat e restrições alimentares diferenciais atuando acentuadamente sobre um dos sexos (Turra \& Leite, 2000).

Em todos dos bimestres coletados a razão sexual esteve a favor das fêmeas, e em apenas um deles a proporção foi significativamente diferente de 1:1 $(p>0,05)$ (maio/2009). A razão sexual dentre as classes de tamanho apresentou apenas uma diferença a favor dos machos, não significativa, na $2^{\circ}$ classe de tamanho. Em todas outras seis classes de tamanho a razão esteve a favor das fêmeas. Esta população apresentou o padrão "Padrão Predominante" (proposto por Terossi \& Mantelatto, 2010), onde há a 
predominância de um dos sextos que quase todas as classes de tamanho. $\bigcirc$ enviesamento em favor das fêmeas tem sido registrado em outros estudos com callianassídeos, principalmente registrada em classes de tamanhos de indivíduos maduros [C. macrotelsonis (Rodrigues \& Shimizu, 1997; Shimizu, 1997), como C. major; Sergio mirim (Pezzuto, 1998); Trypaea australiensis (Hailstone \& Stephenson, 1961); Callianassa filholi (Devine, 1966); Lepidophthalmus lovisianensis (Felder \& Lovett, 1989); Neotrypaea californiensis e Callianassa japonica (Tamaki et al., 1997).

Apesar de ser um padrão geral entre os callianassídeos, essa razão sexual em favor das fêmeas não é completamente explicada. Foi sugerido por Rowden \& Jones (1994) que as bombas de sucção podem coletar seletivamente as fêmeas que são mais leves, e que a penetração da bomba de sucção alcança profundidades rasas, que por outro lado poderia dificultar a coleta de machos que estão em tocas mais profundas. Essa hipótese mesmo que considerada razoável, não explica o padrão em espécies ocorrentes em habitats muito diferentes (Pezzuto, 1998). Outra explicação para isso seria a movimentação das fêmeas ovígeras para a parte superior das galerias, para prover maior ventilação aos ovos ou então para eclosão dos mesmos, e devido a isso, seriam capturadas com maior facilidade (Nates \& Felder, 1999; Botter-Carvalho et al., 2007). Essa última hipótese foi corroborada com Callianassa subterranea (Rowden \& Jones, 1994), entretanto não tem nenhuma relação com o observado com C. macrotelsonis (vide Capítulo II).

Interações agonísticas em machos adultos de Callianassidae têm sido registradas na literatura científica (Felder \& Lovett, 1989; Tamaki et al., 1997; Shimoda et al., 2005), incluindo C. macrotelsonis (Rodrigues \& Shimizu, 1997, como C. major). Lutas intraespecíficas podem ser uma resposta ao alto 
investimento energético na construção e manutenção das tocas (Rodrigues, 1983). No entanto, esta pode não ser a única razão para os confrontos. Após o assentamento, a maioria dos Axiidea permanece confinado no interior das galerias, sendo que os animais também dependem das tocas para os encontros sexuais (Pohl, 1946). Estes crustáceos possuem hábitos solitários e dependem de encontros casuais entre as tocas para se acasalar (em um ambiente tridimensional). A redução na densidade de machos maduros sexualmente pode se dar através das lutas (que selecionam os "melhores" exemplares, e maximiza a probabilidade do macho sobrevivente encontrar fêmeas pela escavação aleatória) (Felder \& Lovett, 1989). Assim, a ocorrência de razões sexuais enviesados em favor das fêmeas (após a maturação sexual) em Axiidea pode ter evoluído como uma estratégia alternativa para resolver o problema de encontros sexuais dentro sedimento, sem recorrer às estratégias frequentemente utilizadas por outros grupos da infauna (e. g. hábitos gregários, densidades populacionais extremamente altas, feromônios, fecundação externa, etc.) (Pezzuto, 1998).

A densidade de C. macrotelsonis na praia do Perequê-açu é caracterizada pela oscilação entre picos seguidos por decréscimos no número de indivíduos por metro-2. Os picos foram observados em novembro/2008, março e maio/2009. Vale ressaltar que a queda na densidade observada em janeiro/2009 foi, muito provavelmente, influenciada pela elevada extração de corruptos para iscas nos meses de verão. Quando comparada às outras populações de C. macrotelsonis, a densidade da população residente na praia do Perequê-açu $\left(0,202 \pm 0,494 \mathrm{ab} \cdot \mathrm{m}^{-2}\right)$ apresenta valores muito inferiores a outros estudos realizados no Estado de São Paulo, máximo 6,1 ab. $\bullet \mathrm{m}^{-2}$ e mínimo 2 ab. $• \mathrm{~m}^{-2}$ (Shimizu, 1997; Shimizu \& Rosso, 2000); no Paraná, variando 
de $4,48 \mathrm{ab} \cdot \bullet \mathrm{m}^{-2}$ antes do verão, e 5,34 ab. $\bullet \mathrm{m}^{-2}$ após o verão (Souza \& Borzone, 2003); e no Rio de Janeiro, com média de $12,97 \pm 8,5 \mathrm{ab} \cdot \bullet \mathrm{m}^{-2}$ (Simão et al., 2006).

Mudanças sazonais na densidade em callianassideos de praias arenosas são geralmente atribuídas a eventos de recrutamento (Tamaki \& Ingole, 1993; Souza et al., 1998) (neste estudo inferidas indiretamente), como por exemplo o recrutamento no início do verão em C. macrotelsonis no Estado do Paraná (Souza et al., 1998), e em outubro e em junho em São Sebastião/SP (Rodrigues \& Shimizu, 1997). Variações sazonais de juvenis na população são recorrentes em C. macrotelsonis, e atribuídos a fatores com predação, condições ambientais e biogeográficos atuando sobre os indivíduos em estágios larvais (Rodrigues, 1976).

O método de contagem de aberturas de galerias é uma estimativa eficiente da densidade populacional de C. macrotelsonis, já que é uma espécie solitária em suas tocas, e desde que as aberturas não sejam confundidas com as aberturas de outras espécies. Por outro lado, a análise pode ser subestimada por que os indivíduos juvenis não produzem aberturas facilmente identificáveis, devido à baixa atividade destes indivíduos (Rodrigues \& Shimizu, 1997)

A eficiência de captura pode ser um critério subjetivo quando levado em conta que a qualidade das bombas de sucção, assim como a habilidade dos coletores pode influenciar nos resultados obtidos. Entretanto, neste estudo foram usadas sempre as mesmas bombas de sução e o mesmo método de coleta (eficiência de captura média $26,6 \%$ ). O que permite uma comparação confiável dentre os bimestres coletados (mínima de 11,5\%, e máxima de 
43,5\%). Porém devem ser interpretados de forma cautelosa quando comparados com outros estudos.

É conhecido que condições ambientais locais (especialmente a temperatura) podem influenciar o período reprodutivo e, consequentemente, a presença de fêmeas ovígeras (e.g., Baver 1992; Lardies \& Castilla 2001; Terossi et al., 2010; Wehrtmann et al., 2012). Os resultados indicam uma reprodução contínua desta espécie na praia do Perequê-açu com exceção de maio/2009 (Figura 6), baseado na presença quase que constante de fêmeas ovígeras, o que sugere uma constante entrada de juvenis na população (no entanto não observado diretamente neste estudo pela presença dos indivíduos das (reais) menores classes de tamanho, como comentado anteriormente). Ao longo da costa brasileira, tanto a reprodução continua quanto a reprodução sazonal vem sendo reportadas na literatura científica (Tabela 2), entretanto não foi possível identificar um padrão latitudinal quando comparados os dados a respeito de C. macrotelsonis.

Levando-se em consideração o pico de fêmeas ovígeras (novembro/2008) e o período de desenvolvimento larval em C. macrotelsonis [aproximadamente 32 dias em temperaturas em torno de $23^{\circ} \mathrm{C}$ (Rodrigues, 1976)], estima-se, indiretamente, que o recrutamento esteja ocorrendo entre dezembro e janeiro. O que só é refletido efetivamente em maio, com a coleta de indivíduos com tamanhos a partir de 5,95 mm CO. A extração de indivíduos adultos para isca foi relatada como favorecedora do assentamento de juvenis, sendo que isso reduz a competição por espaço no substrato (Rodrigues \& Shimizu, 1997).

Levando-se em conta o caráter econômico da extração destes animais como isca para pesca, o estado de conservação de C. macrotelsonis (como 
C. major) foi avaliado de acordo com os critérios da IUCN - União Internacional para a Conservação da Natureza e de dos Recursos Naturais por Peiró et al. (2012b), com base nos dados disponíveis na literatura científica. A categoria proposta para o táxon foi "Criticamente Ameaçada (CR)" levando-se em consideração a redução do número de indivíduos nas costas sul e sudeste do Brasil, observada ao longo dos últimos 30 anos. As populações de C. macrotelsonis vêm sofrendo impacto por conta da exploração humana direta (extração) e pela ocupação indevida de praias (Peiró et al., 2012b). Baseando-se em dados das regiões sul e sudeste (e. g. Borzone \& Souza 1996, Shimizu \& Rosso 2000, Souza \& Borzone 2003; e o presente estudo), suspeita-se que o mesmo possa ocorrer em outras áreas da distribuição da espécie. Na costa nordeste e norte não há evidências fortes desse declínio, e o uso deste organismo como isca não tem sido registrado (Peiró et al., 2012b).

Com base dos dados analisados, os parâmetros populacionais de C. macrotelsonis variam consideravelmente dentro de sua ampla área de ocorrência (do Pará até Santa Catarina). Sendo assim, se aceita a hipótese nula proposta para este trabalho $\left(\mathrm{H}_{0}\right.$ : onde existem diferenças entre os parâmetros populacionais nas diferentes populações). Neste estudo comparativo formam sumarizadas características gerais das populações estabelecidas no Brasil; e por meio deste levantamento incentivam-se estudos populacionais em regiões onde não existem registros na literatura (principalmente nas costas Norte e Nordeste do Brasil). Isso também com a finalidade de subsidiar estimativas sobre a conservação da espécie nestes locais. 


\section{Referências}

Abrunhosa, F. A., D. C. B. Arruda, D. J. B. Simith \& C. A. M. Palmeira (2008) The importance of feeding in the larval development of the ghost shrimp Callichirus major (Decapoda: Callianassidae). Anais da Academia Brasileira de Ciências, 80, 445-453.

Abu-Hilal, A., M. Badran \& J. d. Vaugelas (1988) Distribution of trace elements in Callichirus laurae burrows and nearby sediments in the Gulf of Aquaba, Jordan (Red Sea). Marine Environmental Research, 25, 233-248.

Alves E. S. \& P. R. Pezzuto (1998) Population dynamics of Pinnixa patagoniensis Rathbun, 1918 (Brachyura: Pinnotheridae) a symbiotic crab of Sergio mirim (Thalassinidea: Callianassidae) in Cassino Beach, Southern Brazil. Pubblicazioni della Stazione Zoologica di Napoli, Marine Ecology, 19, 3751.

Ayres-Peres, L. \& F. L. Mantelatto (2008) Patterns of distribution of the hermit crab Loxopagurus loxochelis (Moreira, 1901) (Decapoda, Diogenidae) in two coastal areas of southern Brazil. Revista de Biología Marina y Oceanografía, 43, 399-411.

Baver R. T. (1992) Testing generalizations about latitudinal variation in reproduction and recruitment patterns with sicyoniid and caridean shrimp species. Invertebrate Reproduction \& Development, 22, 193-202.

Berkenbusch, K. \& A. A. Rowden (2003) Ecosystem engineering - moving away from 'just-so' stories. New Zealand Journal of Ecology, 27, 67-73.

Berkenbusch, K., A. A. Rowden \& P. K. Probert (2000) Temporal and spatial variation in macrofauna community composition imposed by ghost shrimp Callianassa filholi bioturbation. Marine Ecology Progress Series, 192, 249-257.

Bird, F. L., P. I. Boon \& P. D. Nichols (2000) Physicochemical and microbial properties of burrows of the deposit-feeding thalassinidean ghost shrimp Biffarius arenosus (Decapoda: Callianassidae). Estuarine, Coastal and Shelf Science, 51, 279-291.

Borzone, C. A. \& J. R. B. Souza (1996) A extração de corrupto Callichirus major (Decapoda: Callianassidae) para uso como iscas em praias do litoral do Paraná: características da pesca. Nerítica, 10, 67-79.

Botter-Carvalho, M. L., P. J. P. Santos \& P. V. V. C. Carvalho (2002) Spatial distribution of Callichirus major (Say 1818) (Decapoda: Callianassidae) on a sandy beach, Piedade, Pernambuco, Brazil. Nauplius, 10, 97-109.

Botter-Carvalho, M. L., P. J. P. Santos \& P. V. V. C. Carvalho (2007) Population dynamics of Callichirus major (Say, 1818) (Crustacea, Thalassinidea) on a beach in northeastern Brazil. Estuarine Coastal and Shelf Science, 71, 508-516. 
Branch, G. M. \& A. Pringle (1987) The impact of the sand prawn Callianassa kraussi Stebbing on sediment turnover and on bacteria, meiofauna, and benthic microflora. Journal of Experimental Marine Biology and Ecology, 107, 219-235.

Castro-Filho, B. M., L. B. Miranda \& S. Y. Myao. 1987. Condições hidrográficas na plataforma continental ao largo de Ubatuba: Variações sazonais e em média escala. Boletim do Instituto Oceanográfico, 35, 135-151.

Contessa, L. \& F. L. Bird (2004) The impact of bait-pumping on populations of the ghost shrimp Trypaea australiensis Dana (Decapoda: Callianassidae) and the sediment environment. Journal of Experimental Marine Biology and Ecology, 304, 75-97.

Devine, C. E. (1966) Ecology of Callianassa filholi Milne-Edwards, 1878 (Crustacea, Thalassinidea). Transactions of the Royal Society of New Zealand, 8, 93-110.

Díaz, H. \& J. E. Conde (1989) Population dynamics and life history of the mangrove crab Aratus pisonii (Brachyura, Grapsidae) in a marine environment. Bulletin of Marine Science, 45, 148-163.

Dworschak, P. C. (1988) The biology of Upogebia pusilla (Petagna) (Decapoda, Thalassinidea). III. Growth and Production. Pubblicazioni della Stazione Zoologica di Napoli, Marine Ecology, 9, 51-77.

Dworschak, P. C. (2000) On the burrows of Lepidophthalmus lovisianensis (Schmitt, 1935) (Decapoda: Thalassinidea: Callianassidae). Senckenbergiana Maritima, 30, 99-104.

Felder, D. L. \& D. L. Lovett (1989) Relative growth and sexual maturation in the estuarine ghost shrimp Callianassa lovisianensis Schmitt, 1935. Journal of Crustacean Biology, 9, 540-553.

Fischer, R. A. (1930) The genetical theory of natural selection. 2a Ed. Dover, New York.

Hailstone, T. S. \& W. Stephenson (1961) The biology of Callianassa (Trypaea) australiensis Dana, 1852 (Crustacea, Thalassinidea). University of Queensland Papers: Department of Zoology, 1, 259-285.

Lardies, M. A. \& J. C. Castilla (2001) Latitudinal variation in the reproductive biology of the commensal crab Pinnaxodes chilensis (Decapoda: Pinnotheridae) along the Chilean coast. Marine Biology, 139, 11251133.

Manning R. B. (1975) Two methods for collecting decapods in shallow water. Crustaceana, 29, 317-319. 
Mantelatto, F. L. \& A. Fransozo. (1999) Characterization of the physical and chemical parameters of Ubatuba Bay, northern coast of São Paulo State, Brazil. Revista Brasileira de Biologia, 59, 23-31.

Melo, G. A. S. (1999) Manual de identificação dos Crustacea Decapoda do litoral Brasileiro: Anomura, Thalassinidea, Palinuridea, Astacidea. Editora Plêiade/FAPESP, São Paulo.

Nates, S.F. \& D.L. Felder (1999) Growth and maturation of the ghost shrimp Lepidophthalmus sinuensis Lemaitre \& Rodrigues, 1991 (Crustacea, Decapoda, Callianassidae), a burrowing pest in penaeid shrimp culture ponds. Fishery Bulletin, 97, 541-562.

Peiró, D. F. \& F. L. Mantelatto (2011) Population dynamics of the pea crab Austinixa aidae (Brachyura, Pinnotheridae): a symbiotic of the ghost shrimp Callichirus major (Thalassinidea, Callianassidae) from the southwestern Atlantic. Iheringia, Série Zoologia, 101, 5-14.

Peiró, D. F., P. R. Pezzuto \& F. L. Mantelatto (2011) Relative growth and sexual dimorphism of Austinixa aidae (Brachyura: Pinnotheridae): a symbiont of the ghost shrimp Callichirus major from the southwestern Atlantic. Latin American Journal of Aquatic Research, 39, 261-270.

Peiró, D. F., J. A Baeza \& F. L. Mantelatto. (2012a) Host-use pattern and sexual dimorphism reveals the mating system of the symbiotic pea crab Austinixa aidae (Crustacea: Brachyura: Pinnotheridae). Journal of the Marine Biological Association of the United Kingdom, DOI $10.1017 /$ S0025315412000720

Peiró, D. F., L. Buckup \& F. L. Mantelatto. (2012b) Avaliação do estado da conservação do "corrupto" de praia Callichirus major (Say, 1818) sensu lato (Crustacea, Decapoda, Callianassidae) no Brasil. Biodiversidade Brasileira (no prelo).

Pezzuto, P. R. (1998) Population dynamics of Sergio mirim (Rodrigues 1971) (Decapoda: Thalassinidea: Callianassidae) in Cassino Beach, Southern Brazil. Pubblicazioni della Stazione Zoologica di Napoli, Marine Ecology, 19, 89-109.

Pinheiro, M. A. A. \& O. S. L. Terceiro (2000) Fecundity and reproductive output of the speckled swimming crab Arenaeus cribrarius (Lamarck, 1818) (Brachyura, Portunidae). Crustaceana, 73, 1121-1137.

Pinheiro, M. A. A. \& A. Fransozo (2002) Reproduction of the speckled swimming crab Arenaeus cribrarius (Brachyura: Portunidae) on the Brazilian coast near 2330'S. Journal of Crustacean Biology, 22, 416-428.

Pires-Vanin, A. M. S. (1989) Estrutura e dinâmica da megafauna bêntica na plataforma continental da região norte do Estado de São Paulo. PhD thesis. Instituto Oceanográfico da Universidade de São Paulo, São Paulo, Brazil. 
Pohl, M. E. (1946) Ecological observations on Callianassa major Say at Beaufort, North Carolina. Ecology, 27, 71-80.

Ramos, M. F., D. S. Simão, A. Soares-Gomes (2007) Aspectos reprodutivos de Callichirus major (Say, 1818) (Crustacea: Thalassinidea) na Praia Rasa, Armacão dos Búzios, RJ. In: Anais do XII Congresso Latino-Americano de Ciências do Mar, 15-19 April 2007, Florianópolis.

Rodrigues S. A. (1966) Estudos sobre Callianassa: Sistemática, Biologia e Anatomia. PhD thesis. Faculdade de Filosofia Ciências e Letras da Universidade de São Paulo, São Paulo, Brazil.

Rodrigues, S. A. (1976) Sobre a reprodução, embriologia e desenvolvimento larval de Callichirus major Say, 1818 (Crustacea, Decapoda Thalassinidea). Boletim de Zoologia Universidade de São Paulo, 1, 85104.

Rodrigues, S. A. (1983) Aspectos da biologia de Thalassinidea do Atlântico tropical americano. Livre Docência Thesis, Instituto de Biociências da Universidade de São Paulo, São Paulo, Brazil.

Rodrigues, S. A. \& R. M. Shimizu (1997) Autoecologia de Callichirus major (Say, 1818). Oecologia Brasiliensis, 3, 155-170.

Rowden, A. A. \& M. B. Jones (1994) A contribution to the biology of the burrowing mud shrimp, Callianassa subterranea (Decapoda: Thalassinidea). Journal of the Marine Biological Association of the United Kingdom, 74, 623-435.

Sastry, A. N. 1983. Ecological aspects of reproduction pp. 179-270. In: Vernberg, F. J. \& W. B. Vernberg (eds.). The Biology of Crustacea VIII. Environmental Adaptations. Academic Press, New York.

Sendim, F. S., G. M. S. Souza, J. P. Mcallan \& R. S. Cardoso (2007) Aspectos reprodutivos de Callichirus major em uma praia do Rio de Janeiro. In: Anais do XII Congresso Latino-Americano de Ciências do Mar, 15-19 April 2007, Florianópolis.

Schmiegelow, J. M. M. (2004) O planeta azul: uma introdução às ciências marinhas. Interciência, Rio de Janeiro.

Shimizu, R. M. (1997) Ecologia populacional de Scolelepis squamata (Muller, 1806) (Polychaeta: Spionidae) e Callichirus major (Say, 1818) (Crustacea: Decapoda: Thalassinidae) da Praia de Barequeçaba (São Sebastião, SP). PhD Thesis. Instituto de Biociências da Universidade de São Paulo, São Paulo, Brazil.

Shimizu, R. M. \& S. Rosso (2000) Influence on an oil spill on the abundance of Callichirus major (Say, 1818) on a sandy beach in southeastern Brazil (Crustacea: Decapoda: Thalassinidea). Nauplius, 8, 63-72 
Shimoda, K., Y. Wardiatno, K. Kubo \& A. Tamaki (2005) Intraspecific behaviors and major cheliped sexual dimorphism in three congeneric callianassid shrimps. Marine Biology, 146, 543-557.

Simão, D. S., M. F. Ramos \& A. Soares-Gomes (2006) Population Structure of Callichirus major (Say 1818) (Crustacea: Thalassinidea) in a Sandy Beach of Rio de Janeiro State, Southeast Brazil Coast. Journal of Coastal Research, Special Issue, 39, 1165-1168.

Skilleter, G. A., Y. Zharikov, B. Cameron \& D. P. McPhee (2005) Effects of harvesting callianassid (ghost) shrimps on subtropical benthic communities. Journal of Experimental Marine Biology and Ecology, 320, 133-158.

Souza, J. R. B. \& C. A. Borzone (2003) A extração de corrupto, Callichirus major (Say) (Crustacea, Thalassinidea), para uso como isca em praias do litoral do Paraná: as populações exploradas. Revista Brasileira de Zoologia, 20, 625-630.

Souza, J. R. B., C. A. Borzone, \& T. Brey (1998) Population dynamics and secondary production of Callichirus major (Crustacea, Thalassinidea) on a southern Brazilian sandy beach. Archive of Fishery and Marine Research, 46, 151-164.

Strasser K. M. \& D. L. Felder (1998) Settlement cues in successive developmental st ages of the ghost shrimps Callichirus major and C. islagrande (Crustacea: Decapoda: Thalassinidea). Marine Biology, 132, 599-610.

Strasser K. M. \& D. L. Felder (1999) Settlement cues in an Atlantic coast population of the ghost shrimp Callichirus major (Crustacea: Decapoda: Thalassinidea). Marine Ecology Progress Series, 183, 217-225.

Sturges, H. A. (1926) The choise of a class interval. Journal of the American Statistical Association, 21, 65-66. apud Beer, C. F. \& J. W. H. Swanepoel (1999) Simple and effective number-of-bins circumference selectors for a histogram. Statistics and Computing, 9, 27-35.

Suchanek, T. H. (1983) Control of seagrass communities and sediment distribution by Callianassa (Crustacea, Thalassinidea) bioturbation. Journal of Marine Research, 41, 281-298.

Suchanek, T. H. \& P. L. Colin (1986) Rates and effects fo bioturbation by invertebrates and fishes at Enewetak and Bikini Atolls. Bulletin of Marine Science, 38, 25-34.

Suchanek, T. H., P. L. Colin, G. M. McMurtry \& C. S. Suchanek (1986) Bioturbation and redistribution of sediment radionuclides in Enewetak Atoll lagoon by callianassid shrimp: biological aspects. Bulletin of Marine Science, 38, 144-154. 
Tamaki, A. \& B. Ingole (1993) Distribution of juvenile and adult ghost shrimps, Callianassa japonica Ortmann (Thalassinidea), on an intertidal flat: intraspecific facilitation as a possible pattern- generating factor. Journal of Crustacean Biology, 13, 175-183.

Tamaki, A., B. Ingole, K. Ikebe, K. Muramatsu, M. Taka, \& M. Tanaka (1997) Life history of the ghost shrimp Callianassa japonica Ortmann (Decapoda: Thalassinidea), on an intertidal sandflat in western Kyushu, Japan. Journal of Experimental Marine Biology and Ecology, 210, 223-250.

Terossi, M. \& F. L. Mantelatto (2010) Sexual ratio, reproductive period and seasonal variation of the gonochoric shrimp Hippolyte obliquimanus (Caridea: Hippolytidae). Marine Biology Research, 6, 213-219

Terossi, M., I. S. Wehrtmann \& F. L. Mantelatto (2010) Interpopulational comparison of reproduction of the Atlantic shrimp Hippolyte obliquimanus (Caridea: Hippolytidae). Journal of Crustacean Biology, $30,571-579$.

Turra, A. \& F.P.P. Leite (2000) Population biology and growth of three sympatric species of intertidal hermit crab in south-eastern Brazil. Journal of the Marine Biological Association of United Kingdom, 80, 1061-1069.

Waslenchuk, D. G., E. A. Matson, R. N. Zajac, F. C. Dobbs \& J. M. Tramontano (1983) Geochemistry of burrow waters vented by a bioturbating shrimp in Bermudian waters. Marine Biology, 72, 219-225.

Webb, A. P. \& B. D. Eyre (2004) Effects of natural populations of burrowing thalassinidean shrimp on sediment irrigation, benthic metabolism, nutrient fluxes and denitrification. Marine Ecology Progress Series, 268, 20 220.

Wehrtmann, I. S., I.Miranda, P. Hernáez \& F. L. Mantelatto (2012) Reproductive plasticity in Petrolisthes armatus (Anomura, Porcellanidae): a comparison between a Pacific and an Atlantic population. Helgoland Marine Research, 66, 87-96.

Wenner, A. M. (1972) Sex ratio as a function of size in marine Crustacea. The American Naturalist, 106, 321-350.

Wenner A. M., C. Fusaro \& A. Oaten (1974) Size at onset of sexual maturity and growth rate in crustacean populations. Canadian Journal of Zoology, 52, 1095-1 106.

Wynberg, R. P. \& G. M. Branch (1991) An assessment of bait-collecting for Callianassa kraussi Stebbing in Langebaan Lagoon, western Cape, and of associated avian predation. South African Journal of Marine Science, $11,141-152$.

Wynberg, R. P. \& G. M. Branch (1994) Disturbance associated with baitcollection for sandprawns (Callianassa kraussi) and mudprawns 
(Upogebia africana) - long-term effects on the biota of intertidal sandflats. Journal of Marine Research, 52, 523-558.

Zar J. H. (1996) Biostatistical Analysis. Prentice-Hall, New Jersey.

Ziebis, W., S. Forster, M. Huettel \& B. B. Jorgensen (1996) Complex burrows of the mud shrimp Callianassa truncata and their geochemical impact in the sea bed. Nature, 382, 619-622. 